Supporting Information for

\title{
Rearranged Diels-Alder Adducts and Prenylated Flavonoids as Potential PTP1B Inhibitors from Morus \\ nigra
}

Ke-Jun Qu,${ }^{\dagger}$ Bin Wang, ${ }^{\dagger}$ Chang-Sheng Jiang, ${ }^{\ddagger}$ Bao-Gang Xie,${ }^{\S}$ Ai-Hong Liu, ${ }^{\perp}$ Song-Wei Li, "Yue-Wei Guo," Jia Li, $\|$ and Shui-Chun Mao ${ }^{\dagger}, *$

${ }^{\dagger}$ School of Pharmacy, Nanchang University, 461 Bayi Road, Nanchang 330006, People's Repulic of China.

${ }^{*}$ Jiangxi Province Center for Drug Certification and Evaluation, Nanchang 330046, People’s Republic of China.

${ }^{\S}$ Department of Pharmaceutics, Medical College of Jiaxing University, Jiaxing, 314001, People's Republic of China.

${ }^{\perp}$ Center of Analysis and Testing, Nanchang University, Nanchang 330047, People's Repulic of China.

${ }^{\perp}$ Lushan Botanical Garden, Jiangxi Province \& the Chinese Academy of Sciences, Lushan 332900, People’s Repulic of China.

"State key laboratory of Drug Research, Shanghai Institute of Materia Medica, Chinese Academy of Sciences, Shanghai 201203, People’s Repulic of China.

\section{Corresponding Author}

Tel: +86 791-86818101; Email: maoshuichun@ncu.edu.cn (S.-C. Mao) 


\section{Index}

Figure S1. Positive HRESIMS spectrum of compound 1.

Figure S2. Infrared (IR) spectrum of compound 1.

Figure S3. Ultraviolet (UV) spectrum of compound 1.

Figure S4. ${ }^{1} \mathrm{H}$ NMR spectrum of compound 1 (400 MHz, $\mathrm{CD}_{3} \mathrm{OD}$ ).

Figure S5. ${ }^{13} \mathrm{C}$ NMR spectrum of compound $1\left(100 \mathrm{MHz}, \mathrm{CD}_{3} \mathrm{OD}\right)$.

Figure S6. DEPT 135 spectrum of compound 1 (100MHz, $\left.\mathrm{CD}_{3} \mathrm{OD}\right)$.

Figure S7. ${ }^{1} \mathrm{H}-{ }^{1} \mathrm{H}$ COSY spectrum of compound 1 (400 MHz, $\left.\mathrm{CD}_{3} \mathrm{OD}\right)$.

Figure S8. HSQC spectrum of compound 1 (400 and $100 \mathrm{MHz}, \mathrm{CD}_{3} \mathrm{OD}$ ).

Figure S9. HMBC spectrum of compound 1 (400 and $100 \mathrm{MHz}, \mathrm{CD}_{3} \mathrm{OD}$ ).

Figure S10. Magnified HMBC spectrum of compound 1 (400 and $100 \mathrm{MHz}, \mathrm{CD}_{3} \mathrm{OD}$ ).

Figure S11. Positive HRESIMS spectrum of compound 2.

Figure S12. Infrared (IR) spectrum of compound 2.

Figure S13. Ultraviolet (UV) spectrum of compound 2.

Figure S14. ${ }^{1} \mathrm{H}$ NMR spectrum of compound 2 (400 MHz, $\mathrm{CD}_{3} \mathrm{OD}$ ).

Figure S15. ${ }^{13} \mathrm{C}$ NMR spectrum of compound $2\left(100 \mathrm{MHz}, \mathrm{CD}_{3} \mathrm{OD}\right)$.

Figure S16. ${ }^{1} \mathrm{H}-{ }^{1} \mathrm{H}$ COSY spectrum of compound 2 (400 MHz, $\left.\mathrm{CD}_{3} \mathrm{OD}\right)$.

Figure S17. HSQC spectrum of compound 2 (400 and $100 \mathrm{MHz}, \mathrm{CD}_{3} \mathrm{OD}$ ).

Figure S18. HMBC spectrum of compound 2 (400 and $100 \mathrm{MHz}, \mathrm{CD}_{3} \mathrm{OD}$ ).

Figure S19. Magnified HMBC spectrum of compound 2 (400 and $100 \mathrm{MHz}, \mathrm{CD}_{3} \mathrm{OD}$ ).

Figure S20. Positive HRESIMS spectrum of compound 3.

Figure S21. Infrared (IR) spectrum of compound 3 .

Figure S22. Ultraviolet (UV) spectrum of compound 3.

Figure S23. ${ }^{1} \mathrm{H}$ NMR spectrum of compound 3 (400 MHz, $\mathrm{CD}_{3} \mathrm{OD}$ ).

Figure S24. ${ }^{13} \mathrm{C}$ NMR spectrum of compound 3 (100MHz, $\left.\mathrm{CD}_{3} \mathrm{OD}\right)$.

Figure S25. DEPT 135 spectrum of compound 3 (100MHz, $\left.\mathrm{CD}_{3} \mathrm{OD}\right)$.

Figure S26. ${ }^{1} \mathrm{H}-{ }^{1} \mathrm{H}$ COSY spectrum of compound 3 (400 MHz, $\left.\mathrm{CD}_{3} \mathrm{OD}\right)$.

Figure S27. HSQC spectrum of compound 3 (400 and $100 \mathrm{MHz}, \mathrm{CD}_{3} \mathrm{OD}$ ).

Figure S28. HMBC spectrum of compound 3 (400 and $100 \mathrm{MHz}, \mathrm{CD}_{3} \mathrm{OD}$ ). 
Figure S29. Positive HRESIMS spectrum of compound 4.

Figure S30. Infrared (IR) spectrum of compound 4.

Figure S31. Ultraviolet (UV) spectrum of compound 4.

Figure S32. ${ }^{1} \mathrm{H}$ NMR spectrum of compound 4 (400 $\left.\mathrm{MHz}, \mathrm{CD}_{3} \mathrm{OD}\right)$.

Figure S33. ${ }^{13} \mathrm{C}$ NMR spectrum of compound 4 (100MHz, $\left.\mathrm{CD}_{3} \mathrm{OD}\right)$.

Figure S34. DEPT 135 spectrum of compound 4 (100MHz, CD $\left.{ }_{3} \mathrm{OD}\right)$.

Figure S35. ${ }^{1} \mathrm{H}-{ }^{1} \mathrm{H}$ COSY spectrum of compound 4 (400 MHz, $\mathrm{CD}_{3} \mathrm{OD}$ ).

Figure S36. HSQC spectrum of compound 4 (400 and $100 \mathrm{MHz}, \mathrm{CD}_{3} \mathrm{OD}$ ).

Figure S37. HMBC spectrum of compound 4 (400 and $100 \mathrm{MHz}, \mathrm{CD}_{3} \mathrm{OD}$ ).

Figure S38. Positive HRESIMS spectrum of compound 5.

Figure S39. Infrared (IR) spectrum of compound 5.

Figure S40. Ultraviolet (UV) spectrum of compound $\mathbf{5}$.

Figure S41. ${ }^{1} \mathrm{H}$ NMR spectrum of compound 5 (400 MHz, $\left.\mathrm{CD}_{3} \mathrm{OD}\right)$.

Figure S42. ${ }^{13} \mathrm{C}$ NMR spectrum of compound $5\left(100 \mathrm{MHz}, \mathrm{CD}_{3} \mathrm{OD}\right)$.

Figure S43. DEPT 135 spectrum of compound 5 (100MHz, CD $\left.{ }_{3} \mathrm{OD}\right)$.

Figure S44. ${ }^{1} \mathrm{H}-{ }^{1} \mathrm{H}$ COSY spectrum of compound 5 (400 MHz, $\mathrm{CD}_{3} \mathrm{OD}$ ).

Figure S45. HSQC spectrum of compound 5 (400 and $100 \mathrm{MHz}, \mathrm{CD}_{3} \mathrm{OD}$ ).

Figure S46. HMBC spectrum of compound 5 (400 and $100 \mathrm{MHz}, \mathrm{CD}_{3} \mathrm{OD}$ ).

Figure S47. Positive HRESIMS spectrum of compound 6.

Figure S48. Infrared (IR) spectrum of compound 6.

Figure S49. Ultraviolet (UV) spectrum of compound 6.

Figure S50. ${ }^{1} \mathrm{H}$ NMR spectrum of compound 6 (400 MHz, $\left.\mathrm{CD}_{3} \mathrm{OD}\right)$.

Figure S51. ${ }^{13} \mathrm{C}$ NMR spectrum of compound $6\left(100 \mathrm{MHz}, \mathrm{CD}_{3} \mathrm{OD}\right)$.

Figure S52. DEPT 135 spectrum of compound $6\left(100 \mathrm{MHz}, \mathrm{CD}_{3} \mathrm{OD}\right)$.

Figure S53. ${ }^{1} \mathrm{H}-{ }^{1} \mathrm{H}$ COSY spectrum of compound 6 (400 MHz, $\mathrm{CD}_{3} \mathrm{OD}$ ).

Figure S54. HSQC spectrum of compound 6 (400 and $100 \mathrm{MHz}, \mathrm{CD}_{3} \mathrm{OD}$ ).

Figure S55. HMBC spectrum of compound 6 (400 and $100 \mathrm{MHz}, \mathrm{CD}_{3} \mathrm{OD}$ ).

Figure S56. Positive LRESIMS spectrum of compound 7.

Figure S57. ${ }^{1} \mathrm{H}$ NMR spectrum of compound 7 (400 MHz, $\left.\mathrm{CD}_{3} \mathrm{OD}\right)$.

Figure S58. ${ }^{13} \mathrm{C}$ NMR spectrum of compound 7 (100MHz, $\left.\mathrm{CD}_{3} \mathrm{OD}\right)$. 
Figure S59. DEPT 135 spectrum of compound 7 (100MHz, CD $\left.{ }_{3} \mathrm{OD}\right)$.

Figure S60. Positive LRESIMS spectrum of compound 8.

Figure S61. ${ }^{1} \mathrm{H}$ NMR spectrum of compound 8 (400 MHz, $\left.\mathrm{CD}_{3} \mathrm{OD}\right)$.

Figure S62. ${ }^{13} \mathrm{C}$ NMR spectrum of compound 8 (100MHz, $\left.\mathrm{CD}_{3} \mathrm{OD}\right)$.

Figure S63. DEPT 135 spectrum of compound 8 (100MHz, CD $\left.{ }_{3} \mathrm{OD}\right)$.

Figure S64. Positive LRESIMS spectrum of compound 9.

Figure S65. ${ }^{1} \mathrm{H}$ NMR spectrum of compound 9 (400 MHz, $\left.\mathrm{CD}_{3} \mathrm{OD}\right)$.

Figure S66. ${ }^{13} \mathrm{C}$ NMR spectrum of compound 9 (100MHz, $\left.\mathrm{CD}_{3} \mathrm{OD}\right)$.

Figure S67. Positive LRESIMS spectrum of compound 10.

Figure S68. ${ }^{1} \mathrm{H}$ NMR spectrum of compound 10 (400 MHz, $\left.\mathrm{CD}_{3} \mathrm{OD}\right)$. 


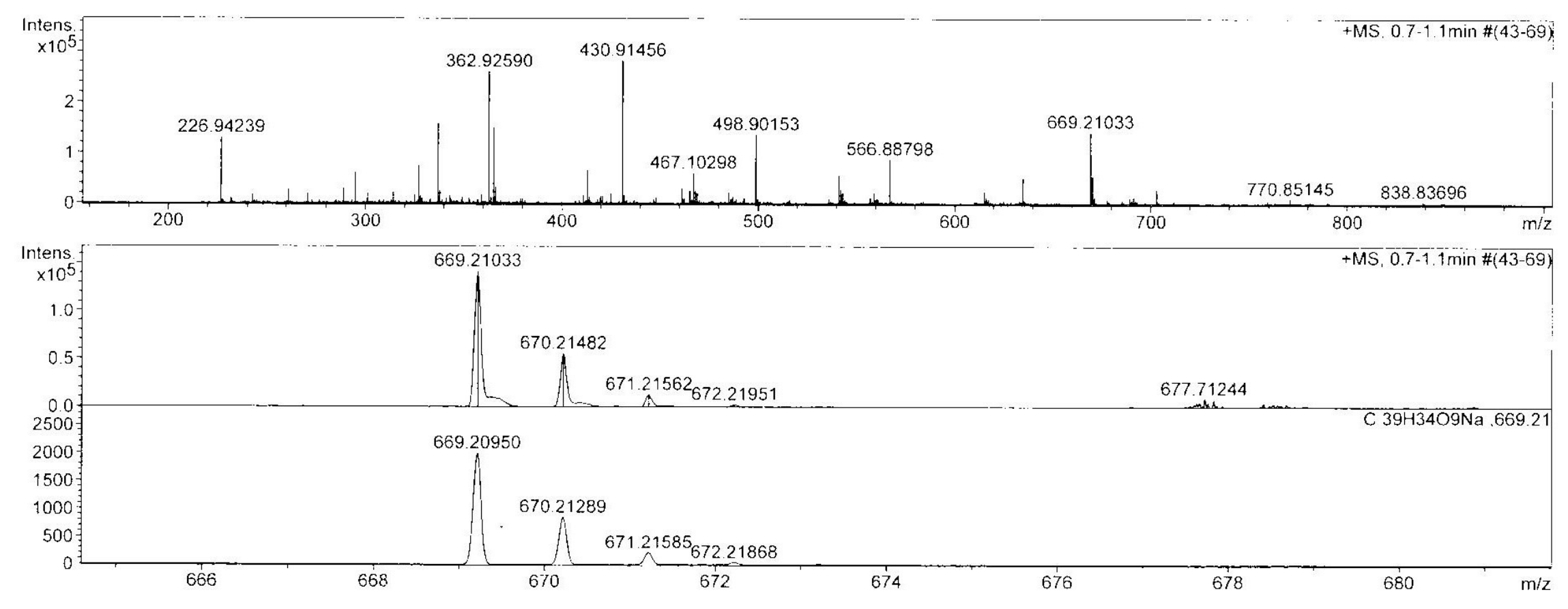

Figure S1. Positive HRESIMS spectrum of compound $\mathbf{1}$. 


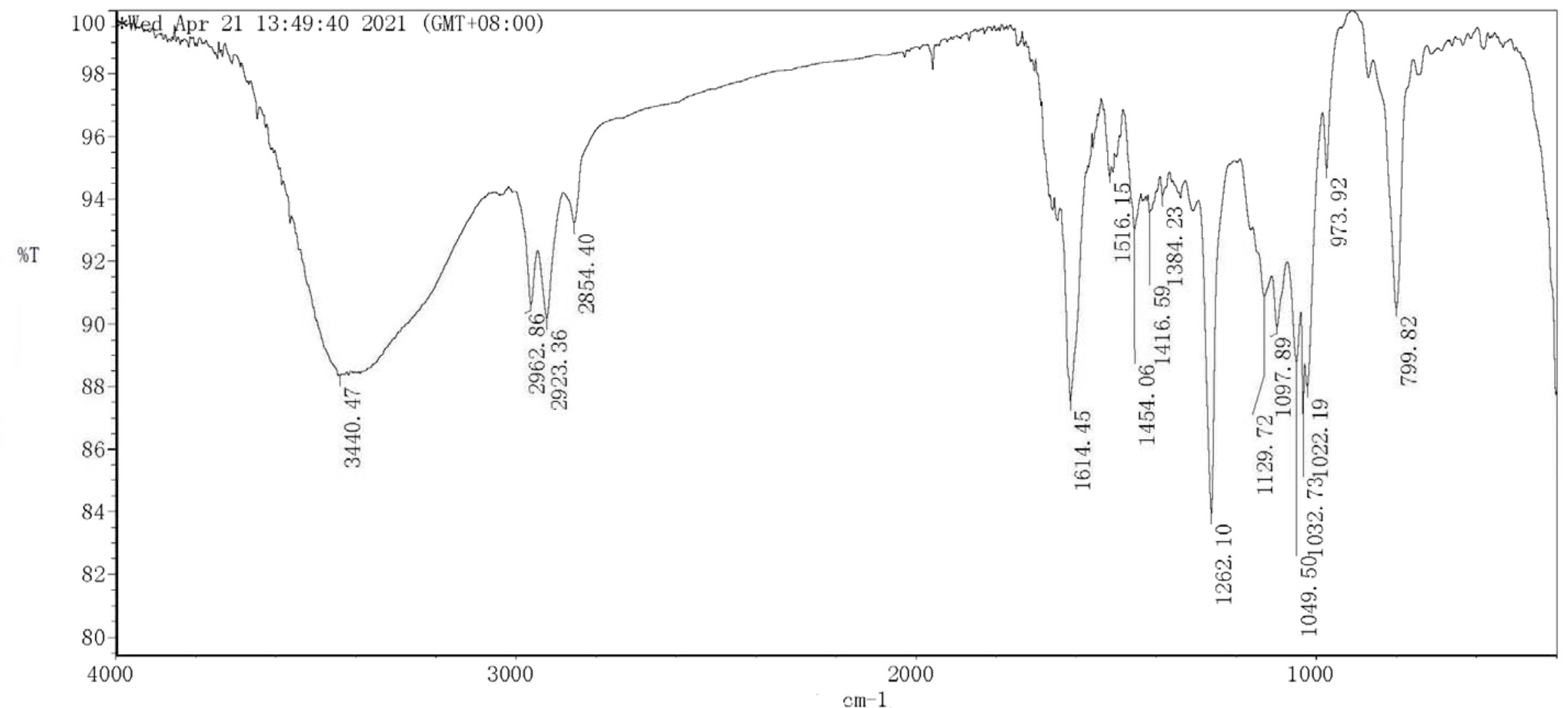

Figure S2. Infrared (IR) spectrum of compound 1. 


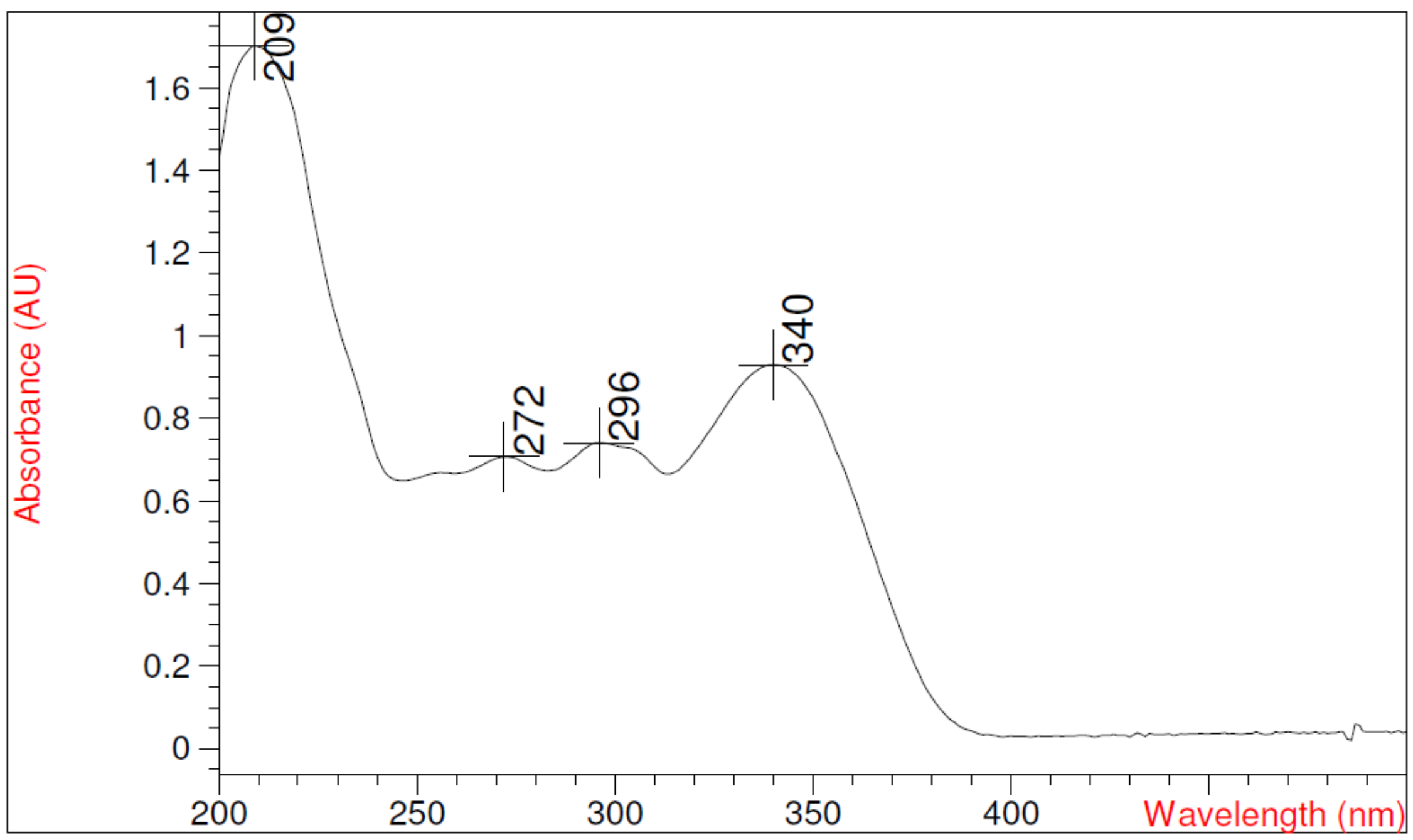

Figure S3. Ultraviolet (UV) spectrum of compound 1. 


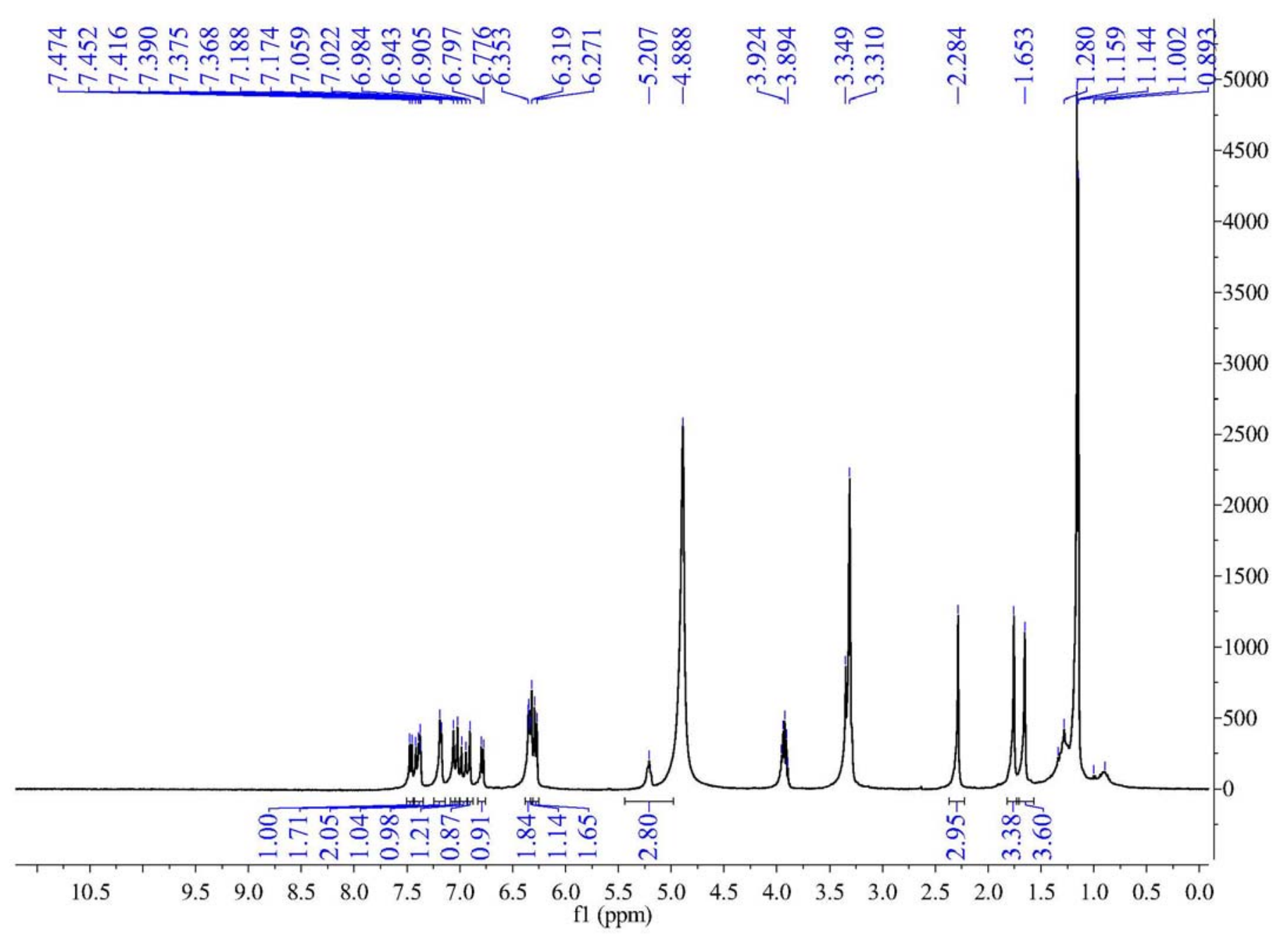

Figure S4. ${ }^{1} \mathrm{H}$ NMR spectrum of compound 1 (400 MHz, $\mathrm{CD}_{3} \mathrm{OD}$ ). 


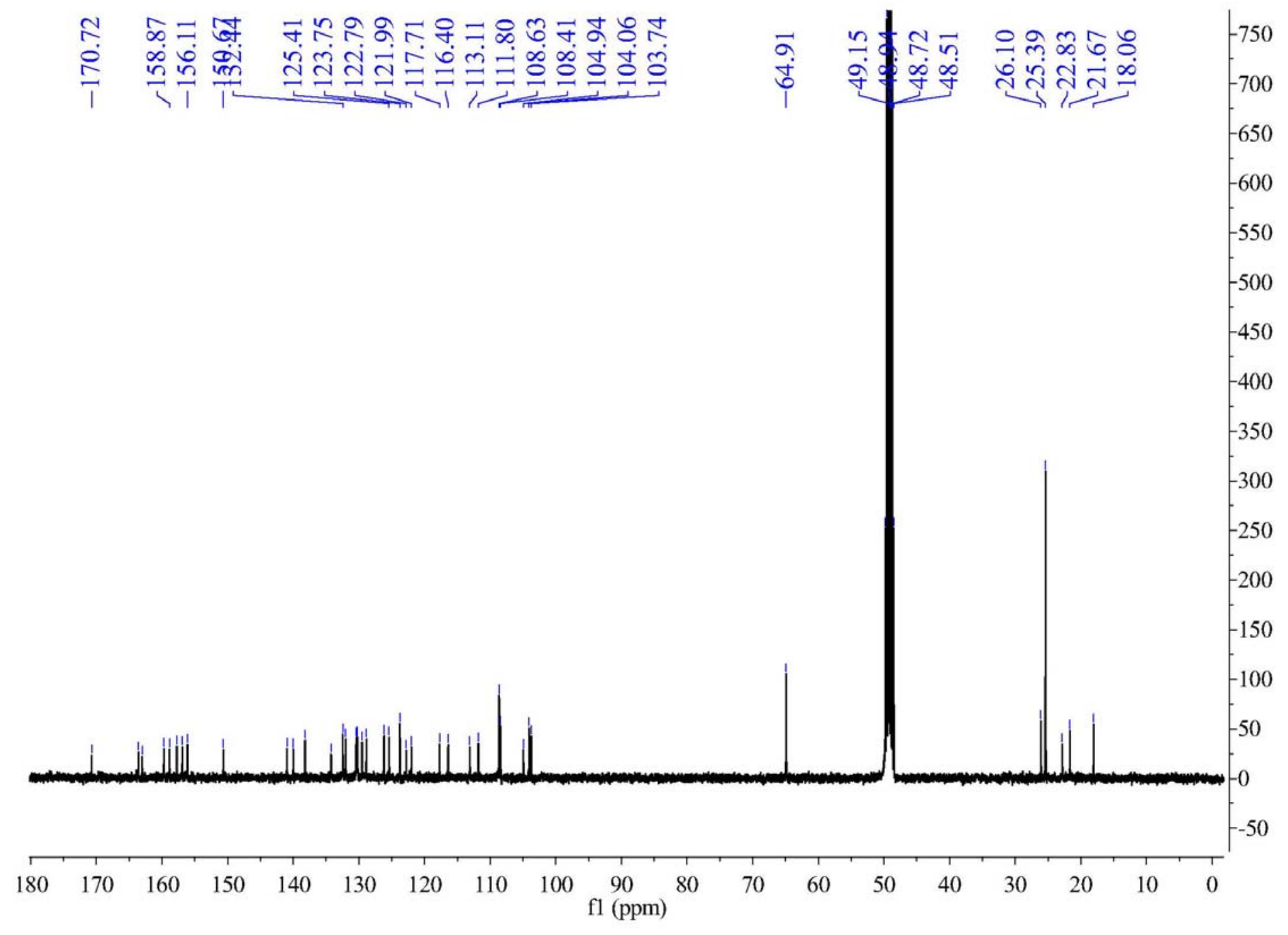

Figure S5. ${ }^{13} \mathrm{C}$ NMR spectrum of compound $1\left(100 \mathrm{MHz}, \mathrm{CD}_{3} \mathrm{OD}\right)$. 


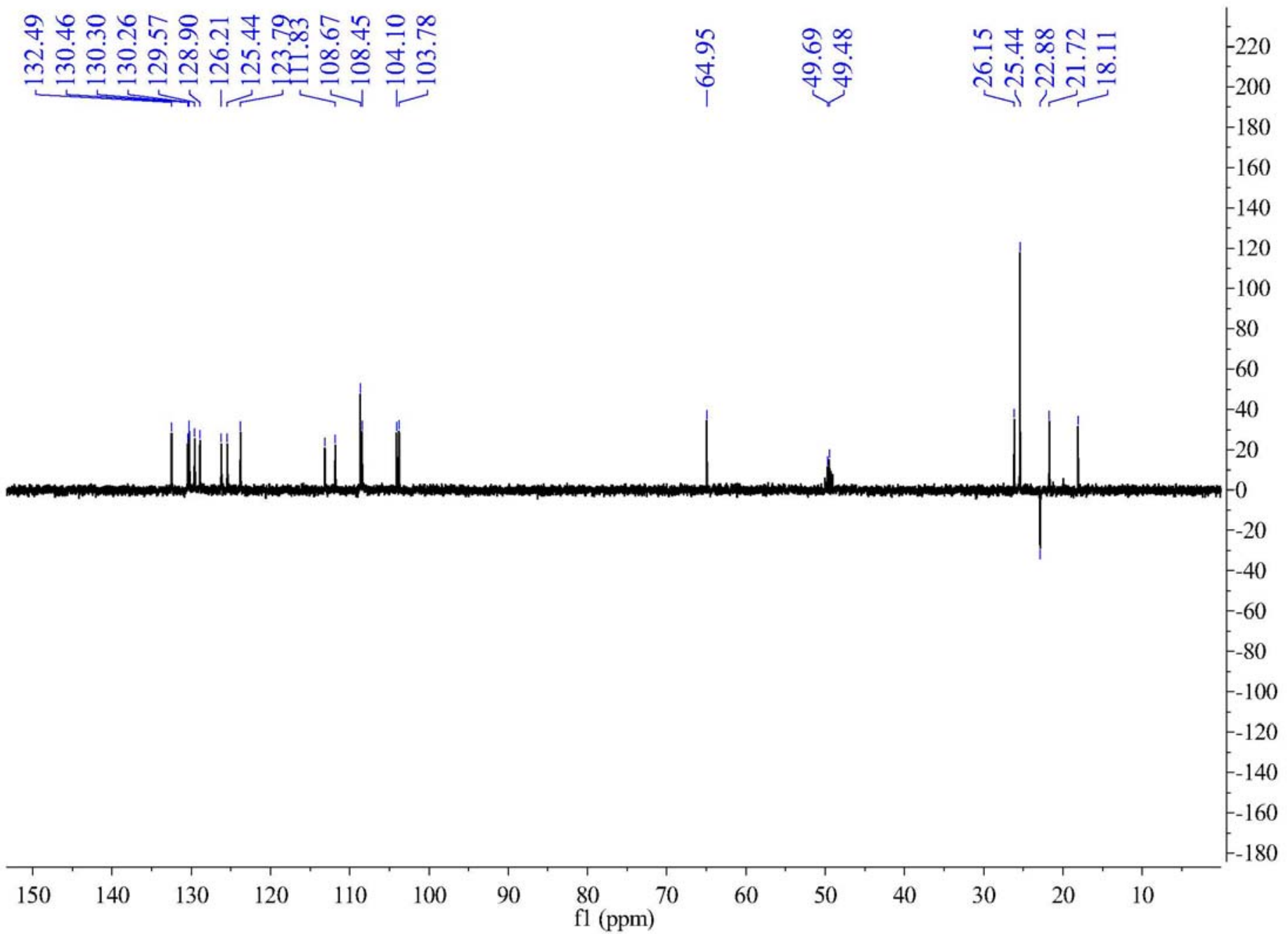

Figure S6. DEPT 135 spectrum of compound 1 (100MHz, CD $3 \mathrm{OD})$. 


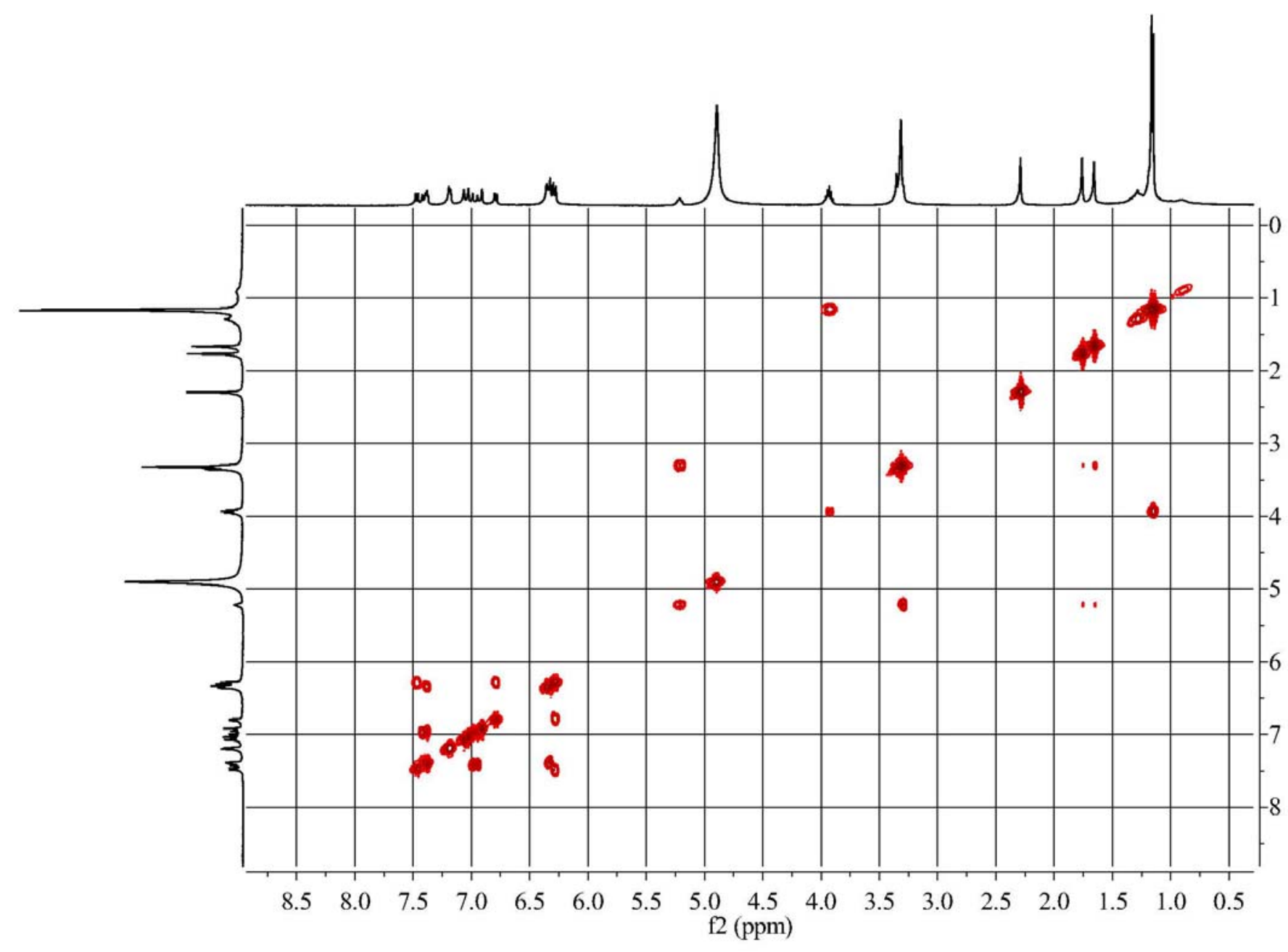

है흔

Figure S7. ${ }^{1} \mathrm{H}-{ }^{1} \mathrm{H}$ COSY spectrum of compound $\mathbf{1}\left(400 \mathrm{MHz}, \mathrm{CD}_{3} \mathrm{OD}\right)$. 


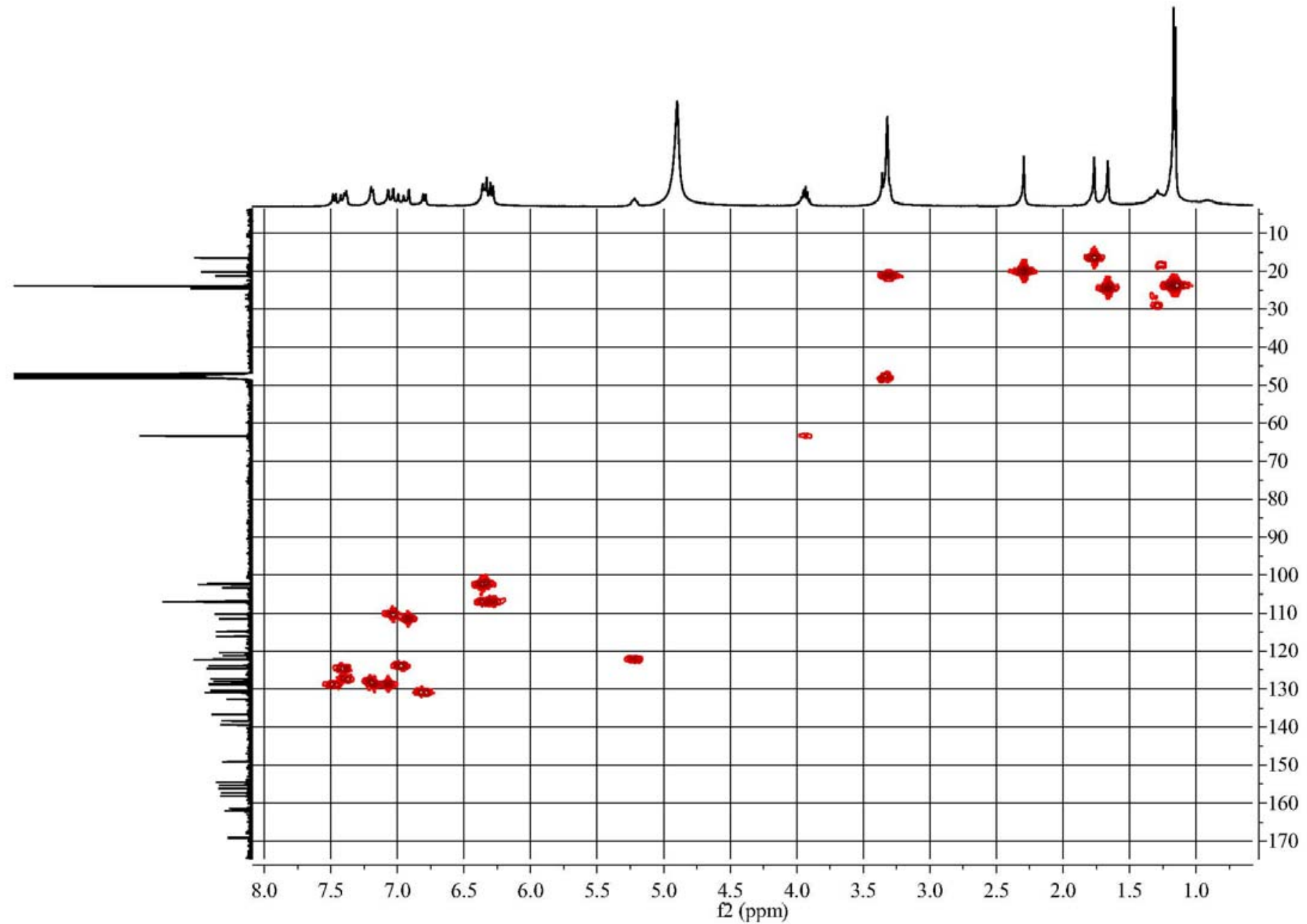

Figure S8. HSQC spectrum of compound 1 (400 and $100 \mathrm{MHz}, \mathrm{CD}_{3} \mathrm{OD}$ ). 


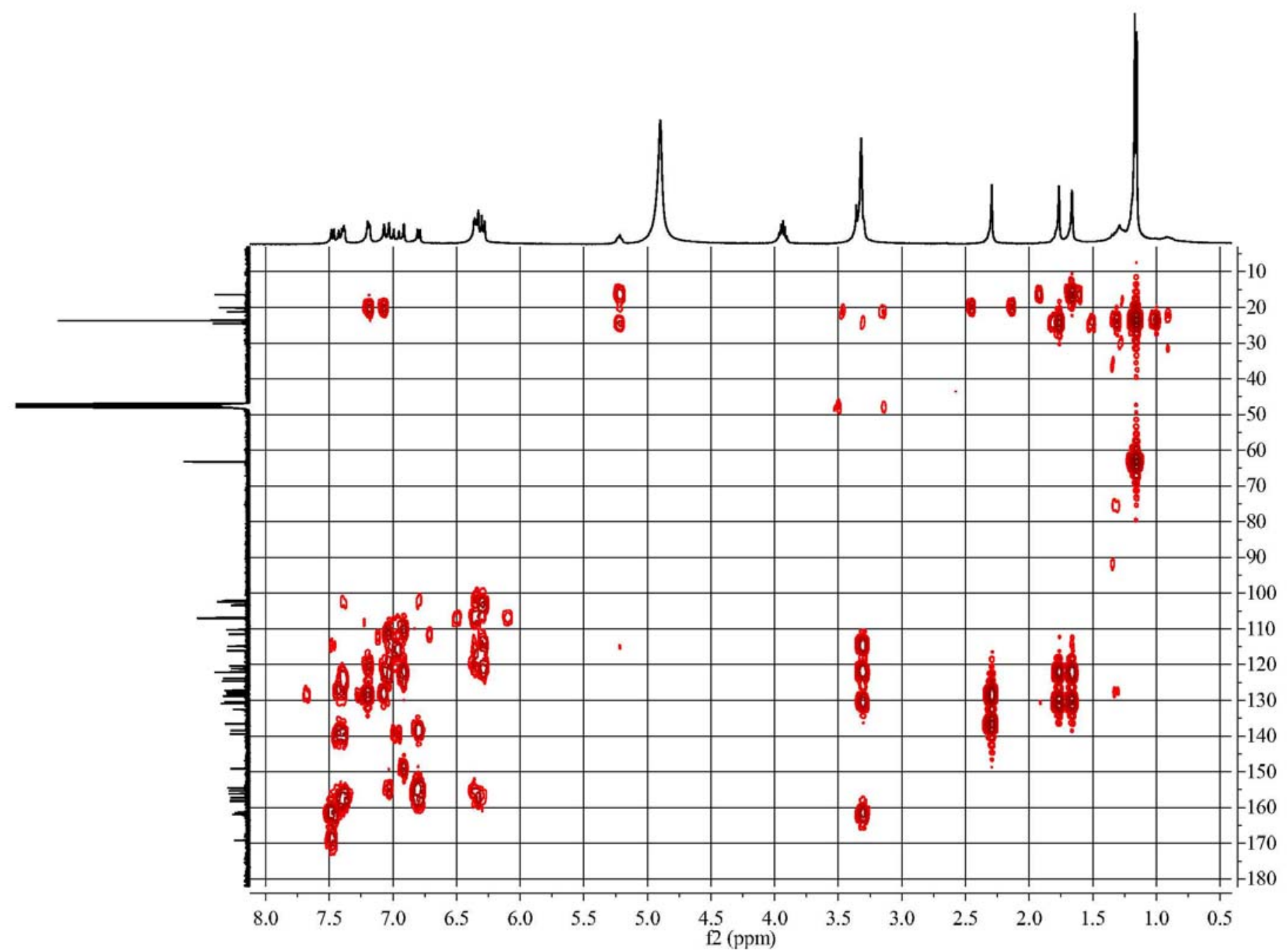

Figure S9. HMBC spectrum of compound 1 (400 and $100 \mathrm{MHz}, \mathrm{CD}_{3} \mathrm{OD}$ ). 


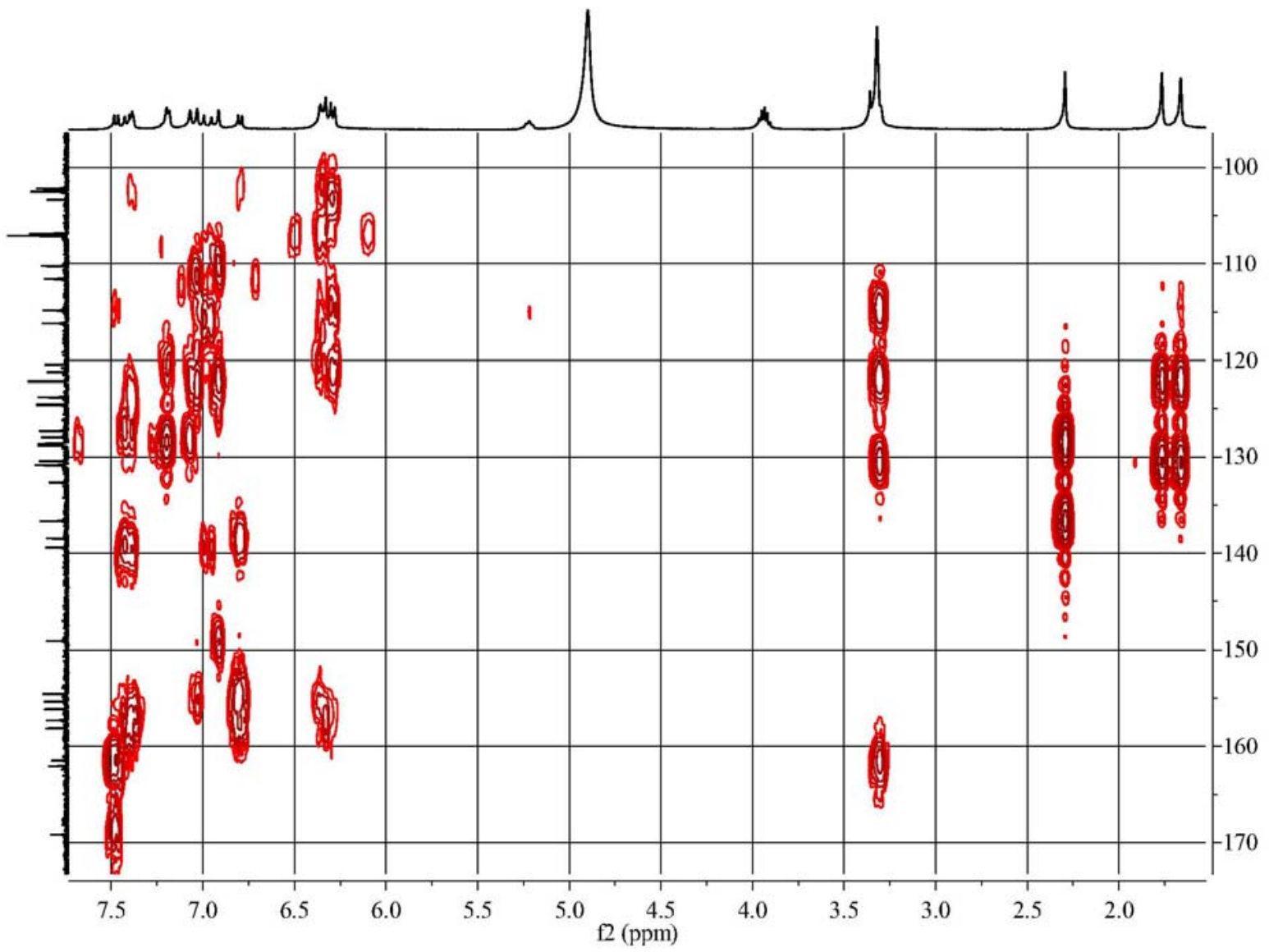

言

Figure S10. Magnified HMBC spectrum of compound 1 (400 and $100 \mathrm{MHz}, \mathrm{CD}_{3} \mathrm{OD}$ ).

14 

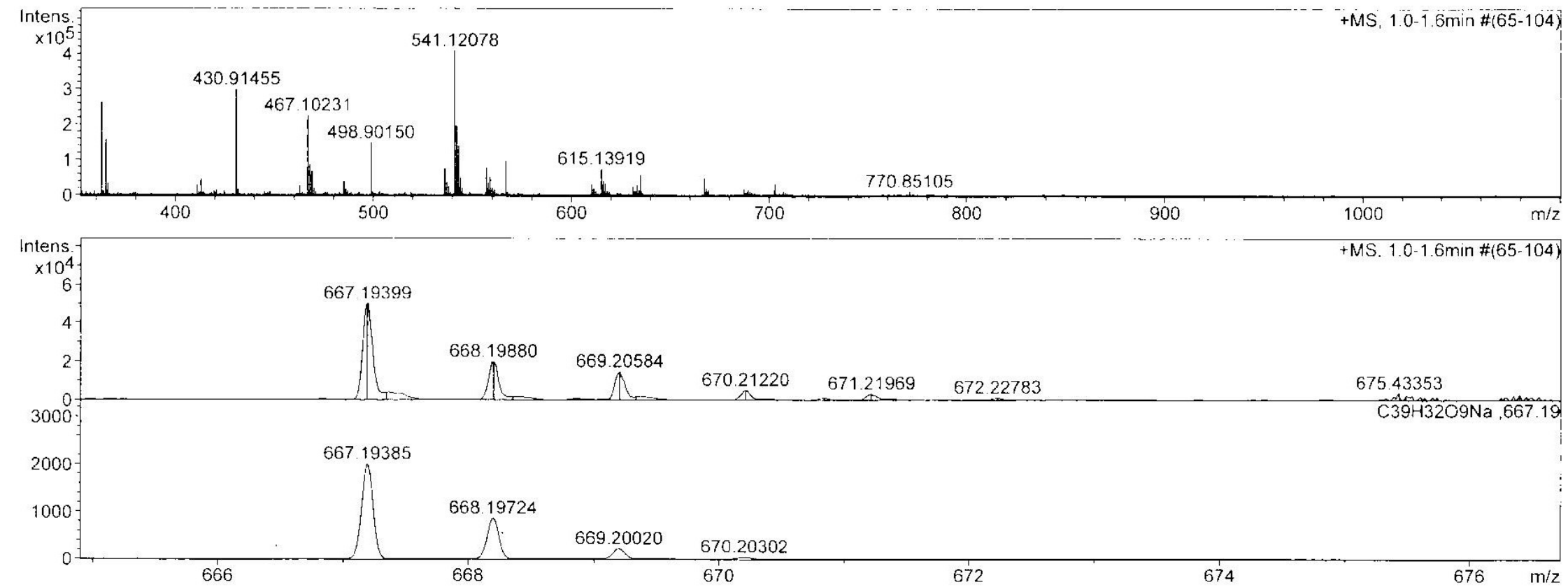

Figure S11. Positive HRESIMS spectrum of compound 2. 


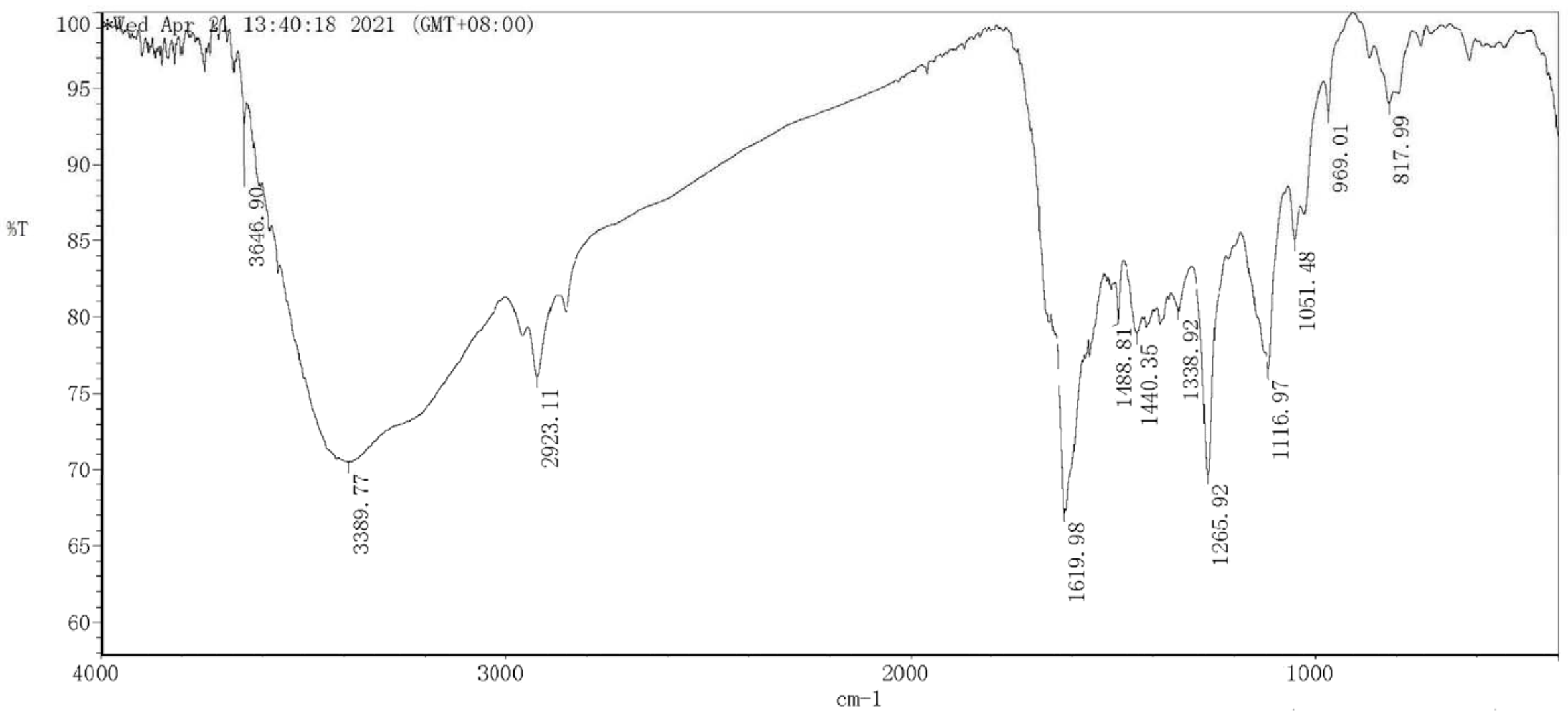

Figure S12. Infrared (IR) spectrum of compound 2. 


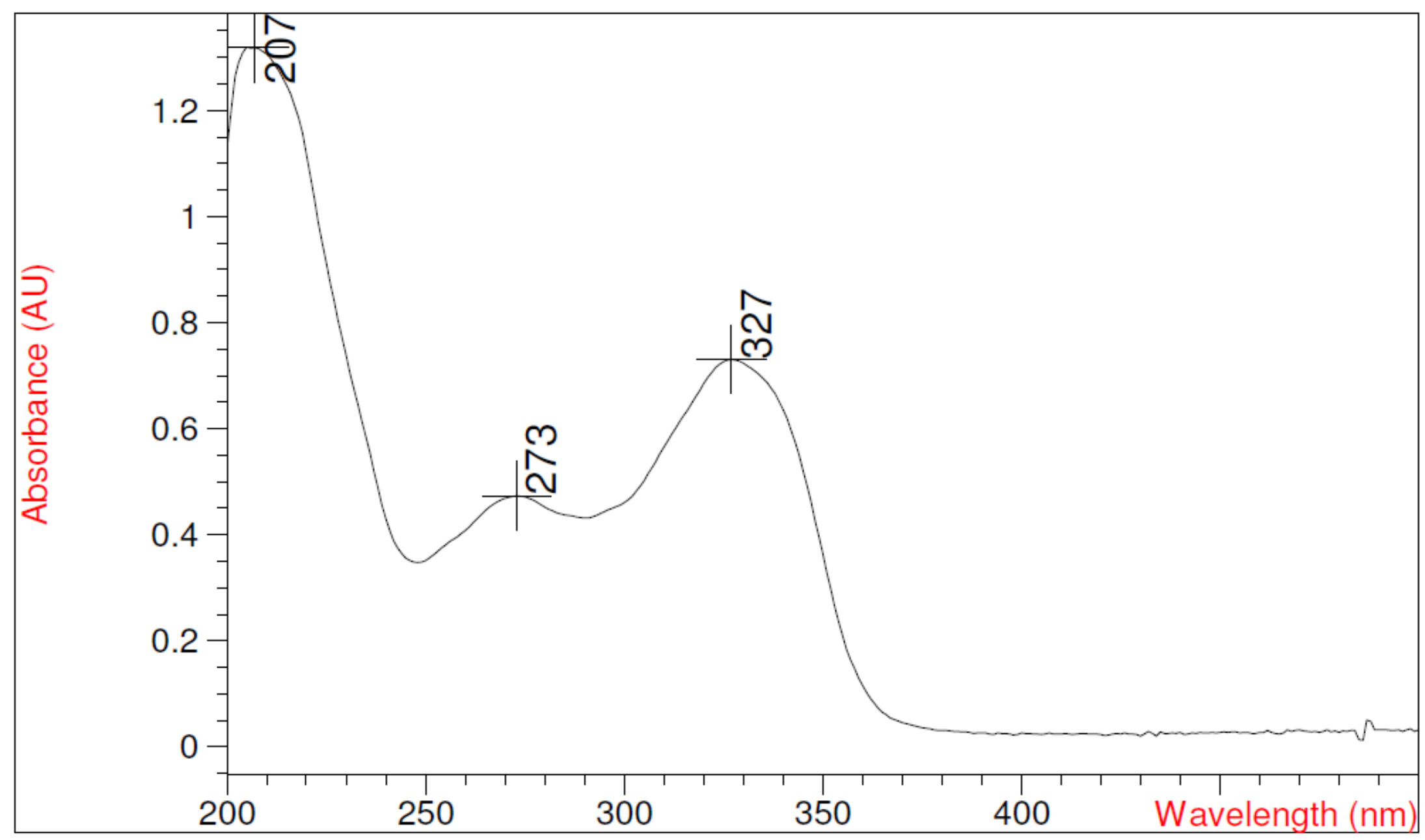

Figure S13. Ultraviolet (UV) spectrum of compound 2. 


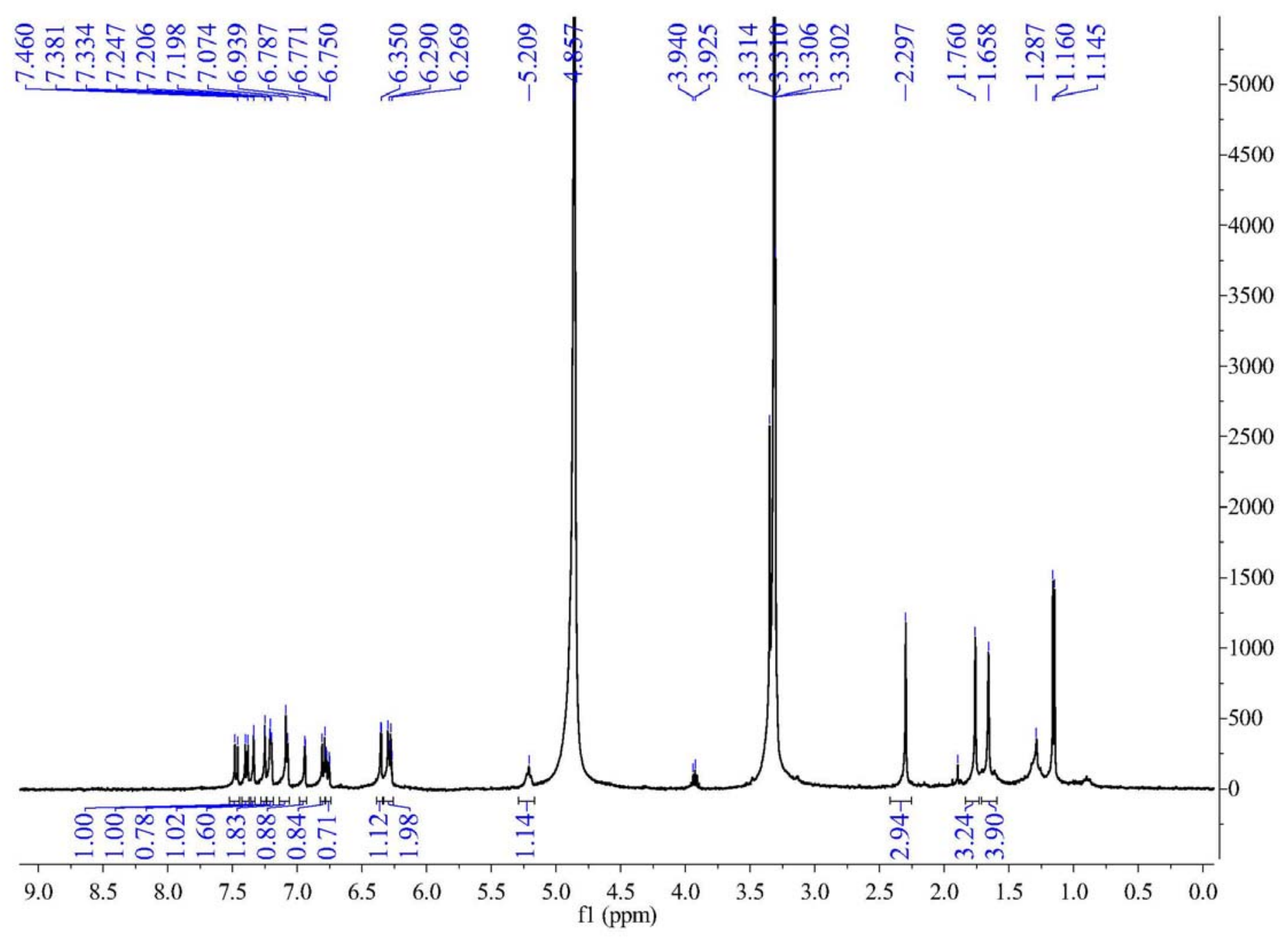

Figure S14. ${ }^{1} \mathrm{H}$ NMR spectrum of compound 2 (400 MHz, $\left.\mathrm{CD}_{3} \mathrm{OD}\right)$. 


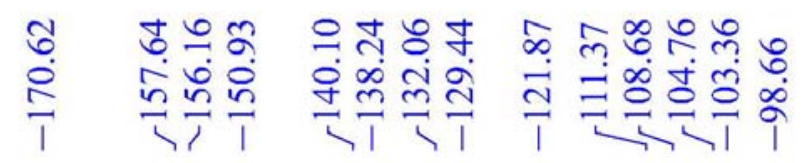

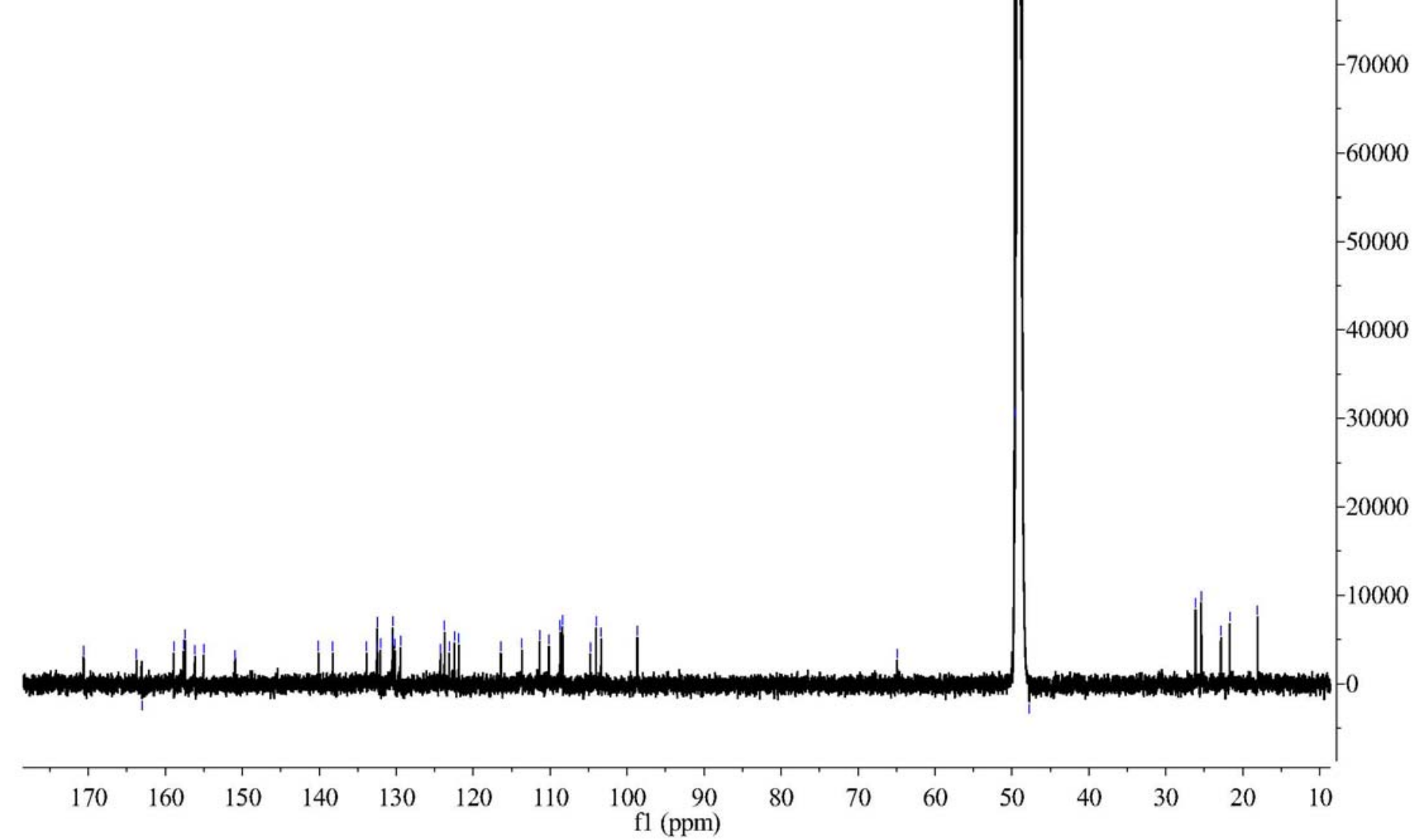

Figure S15. ${ }^{13} \mathrm{C}$ NMR spectrum of compound 2 (100MHz, $\left.\mathrm{CD}_{3} \mathrm{OD}\right)$. 


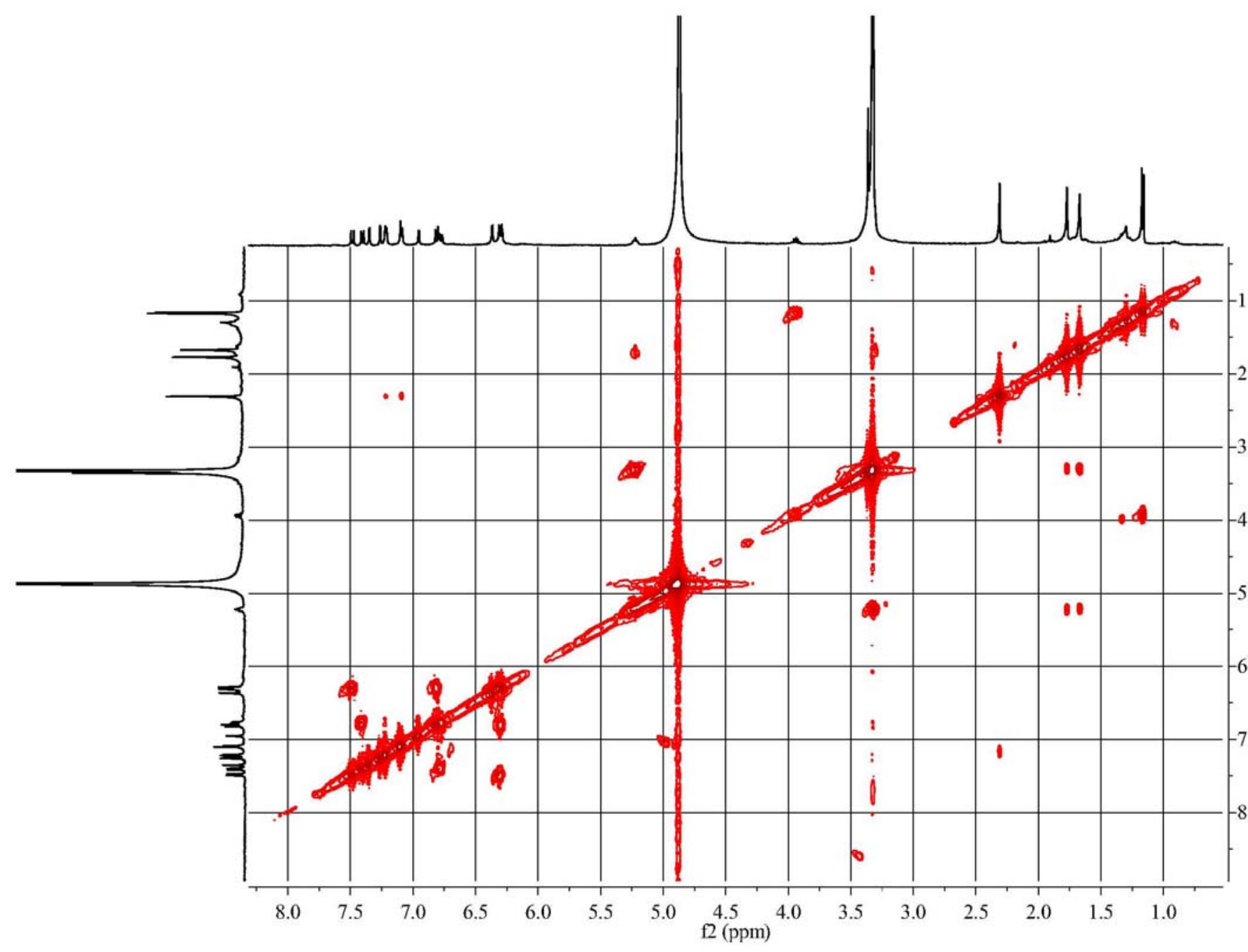

Figure S16. ${ }^{1} \mathrm{H}-{ }^{1} \mathrm{H}$ COSY spectrum of compound 2 (400 MHz, $\mathrm{CD}_{3} \mathrm{OD}$ ). 


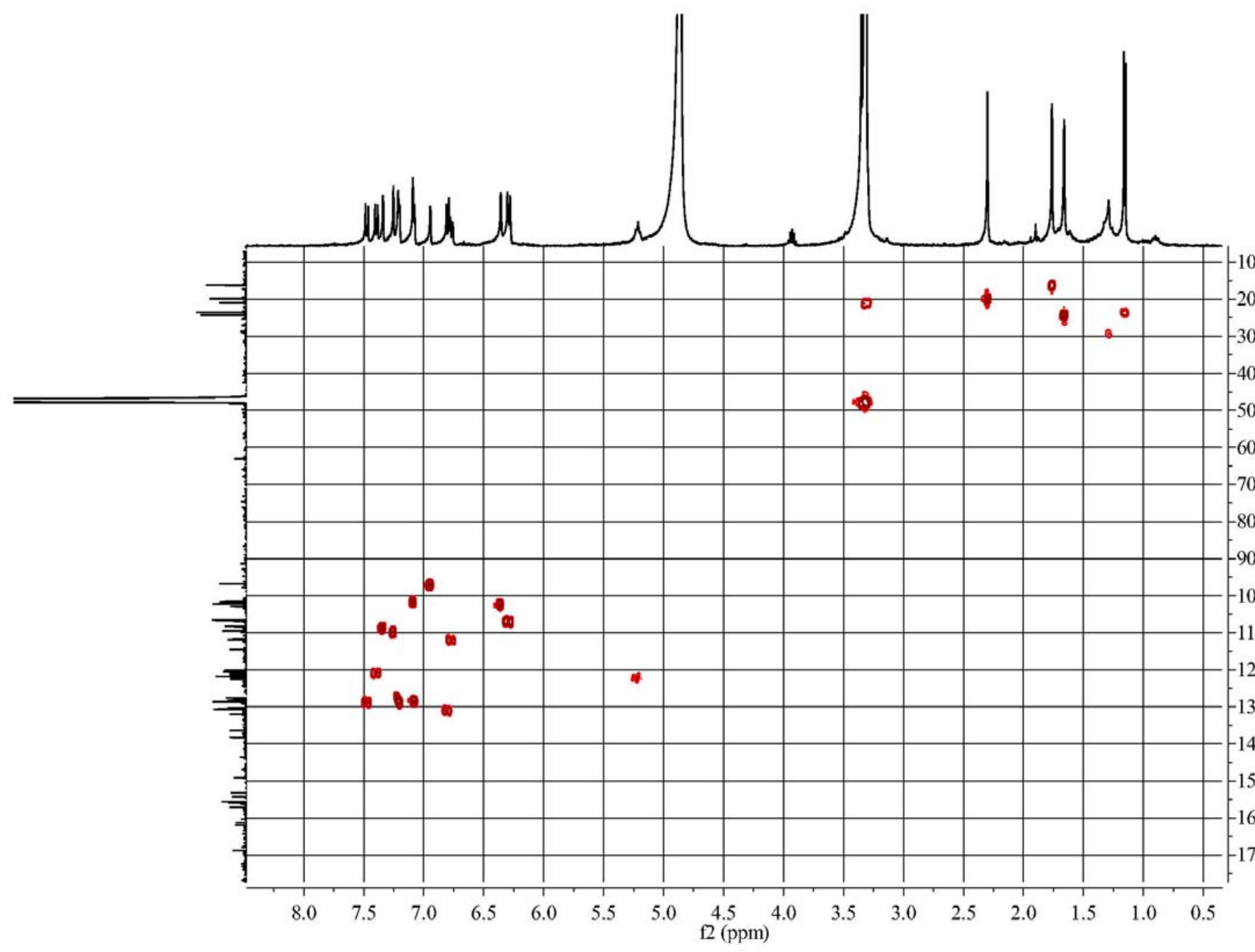

Figure S17. HSQC spectrum of compound 2 (400 and $100 \mathrm{MHz}, \mathrm{CD}_{3} \mathrm{OD}$ ). 


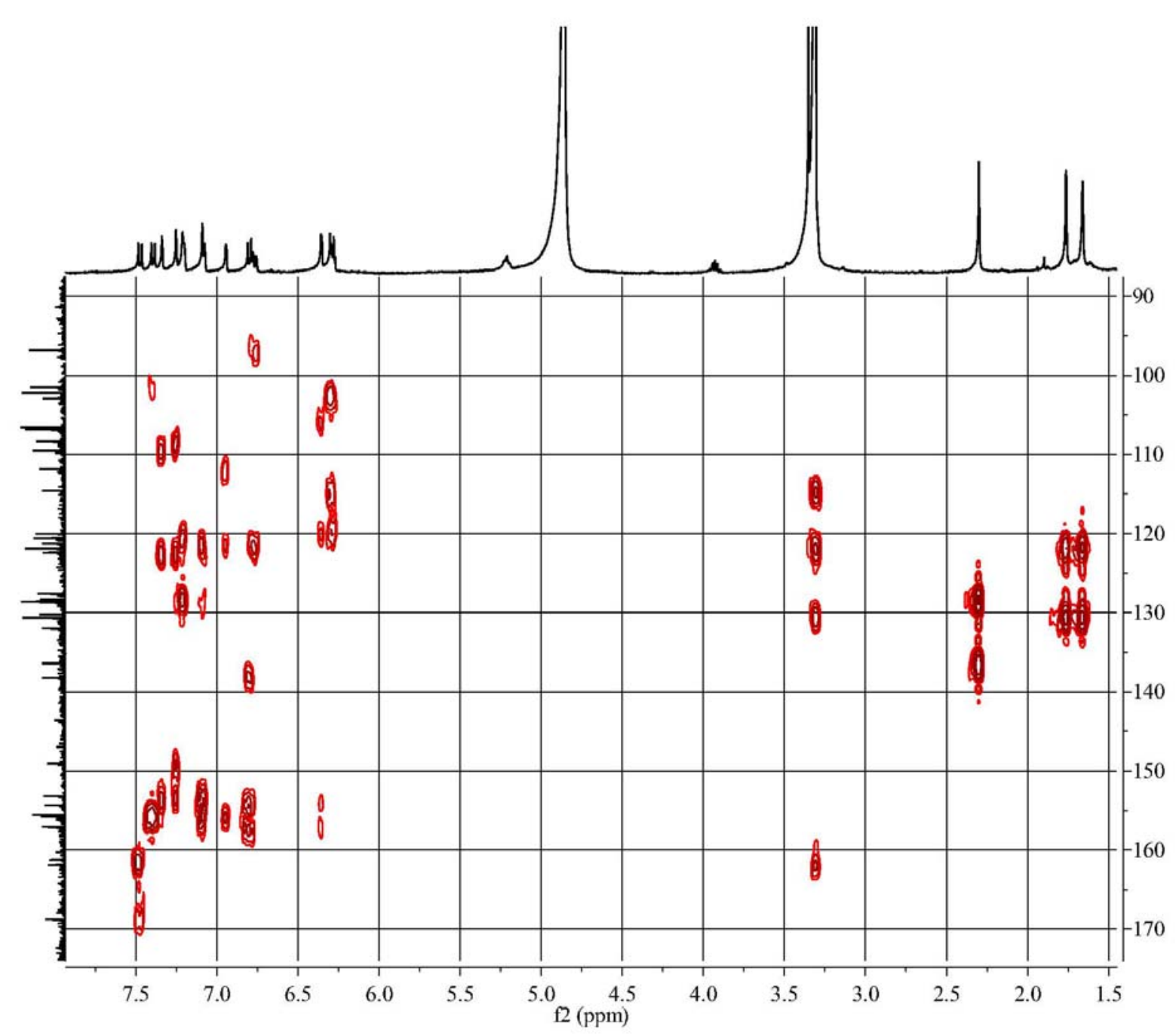

Figure S18. HMBC spectrum of compound 2 (400 and $100 \mathrm{MHz}, \mathrm{CD}_{3} \mathrm{OD}$ ). 


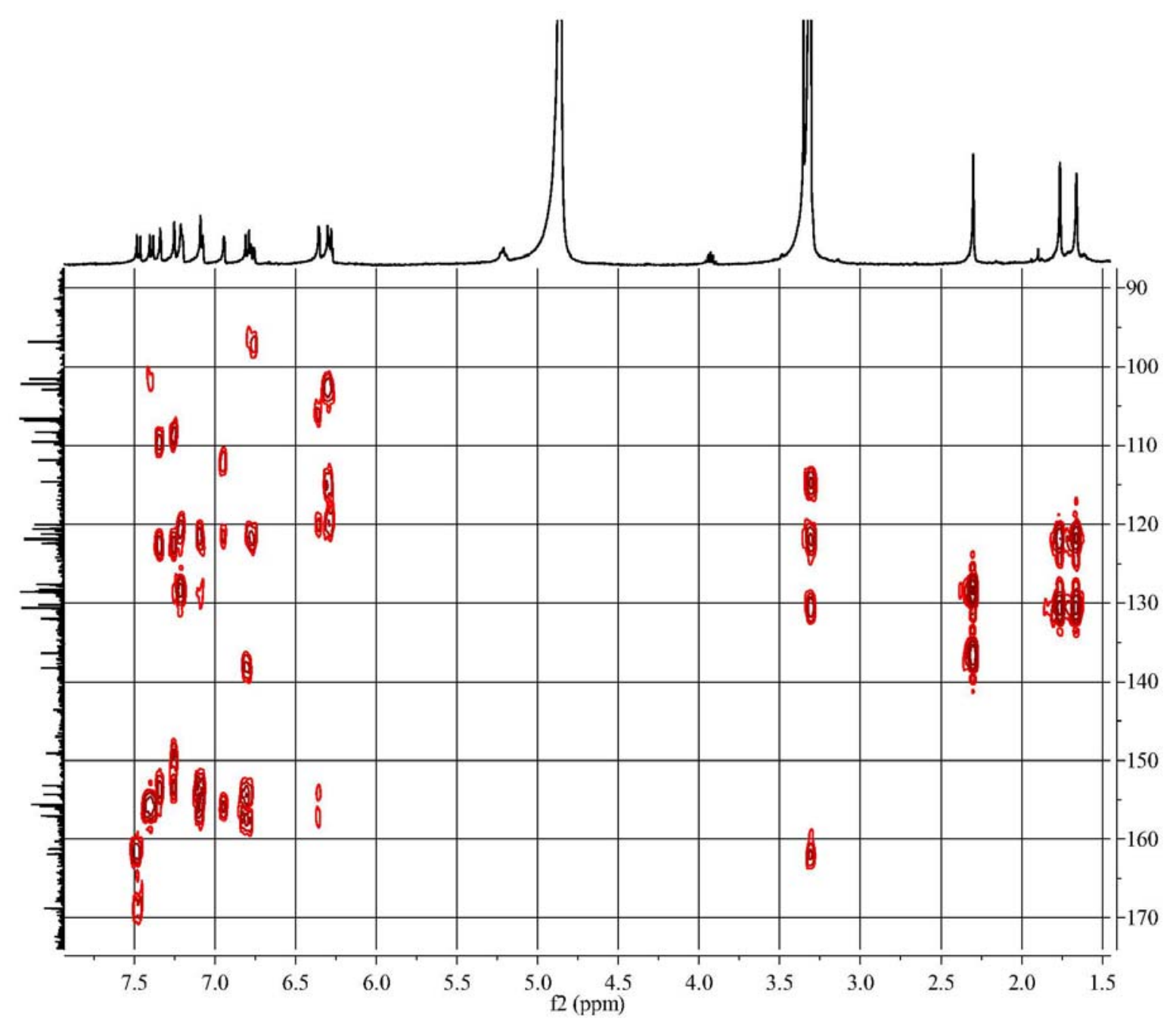

Figure S19. Magnified HMBC spectrum of compound 2 (400 and $100 \mathrm{MHz}, \mathrm{CD}_{3} \mathrm{OD}$ ). 

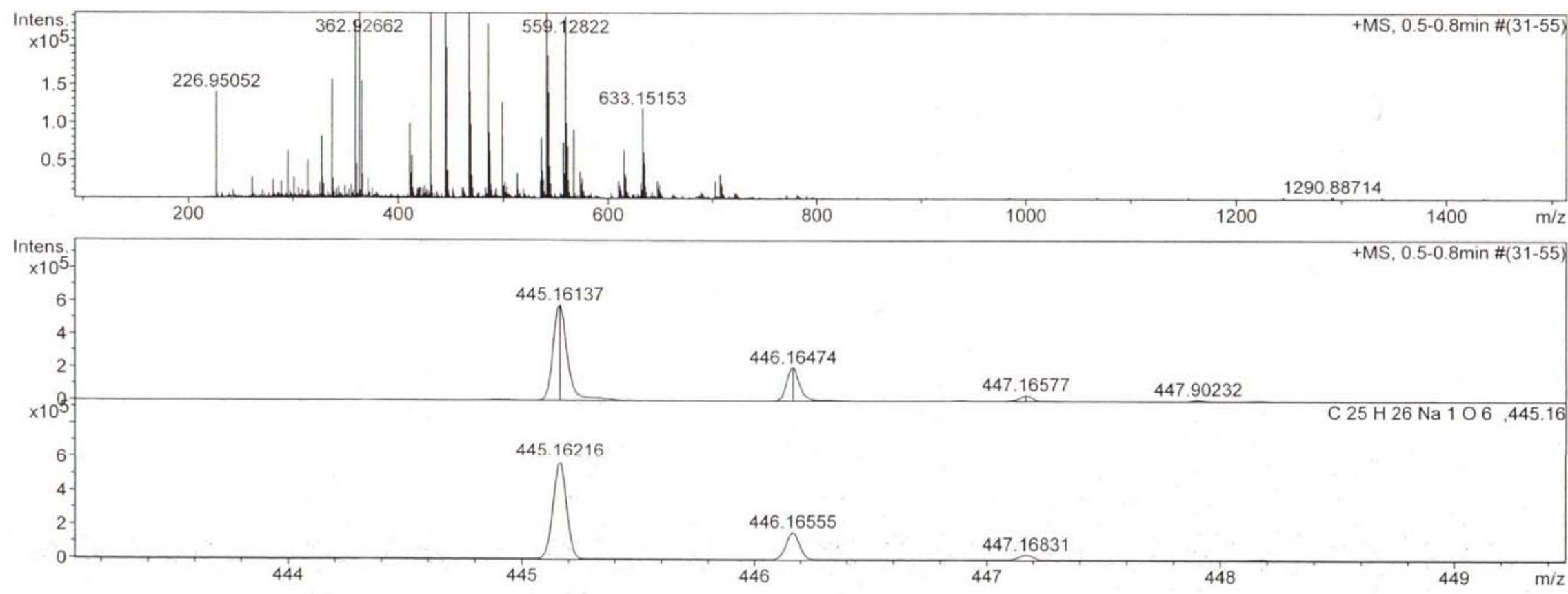

Figure S20. Positive HRESIMS spectrum of compound 3. 


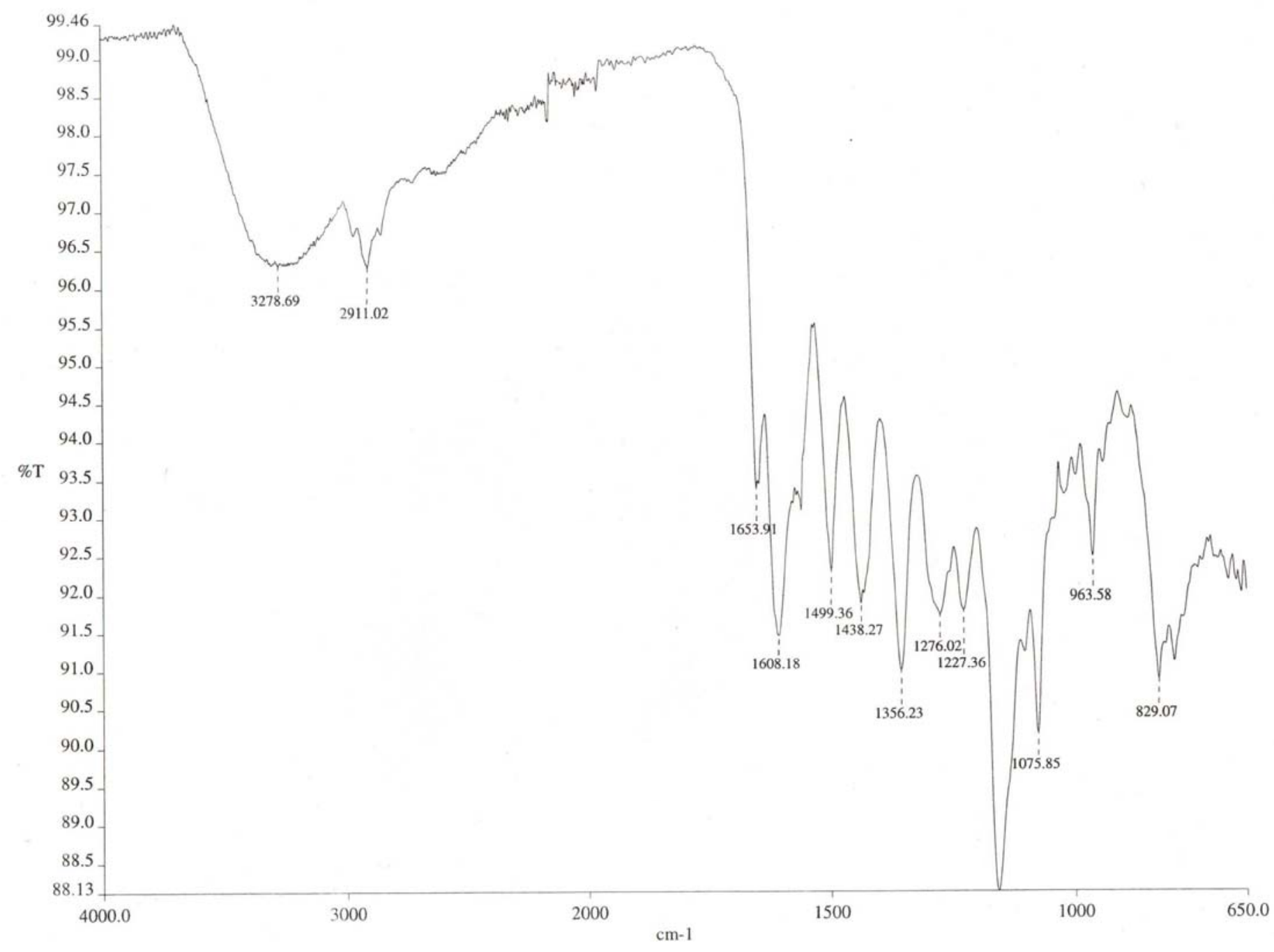

Figure S21. Infrared (IR) spectrum of compound 3. 


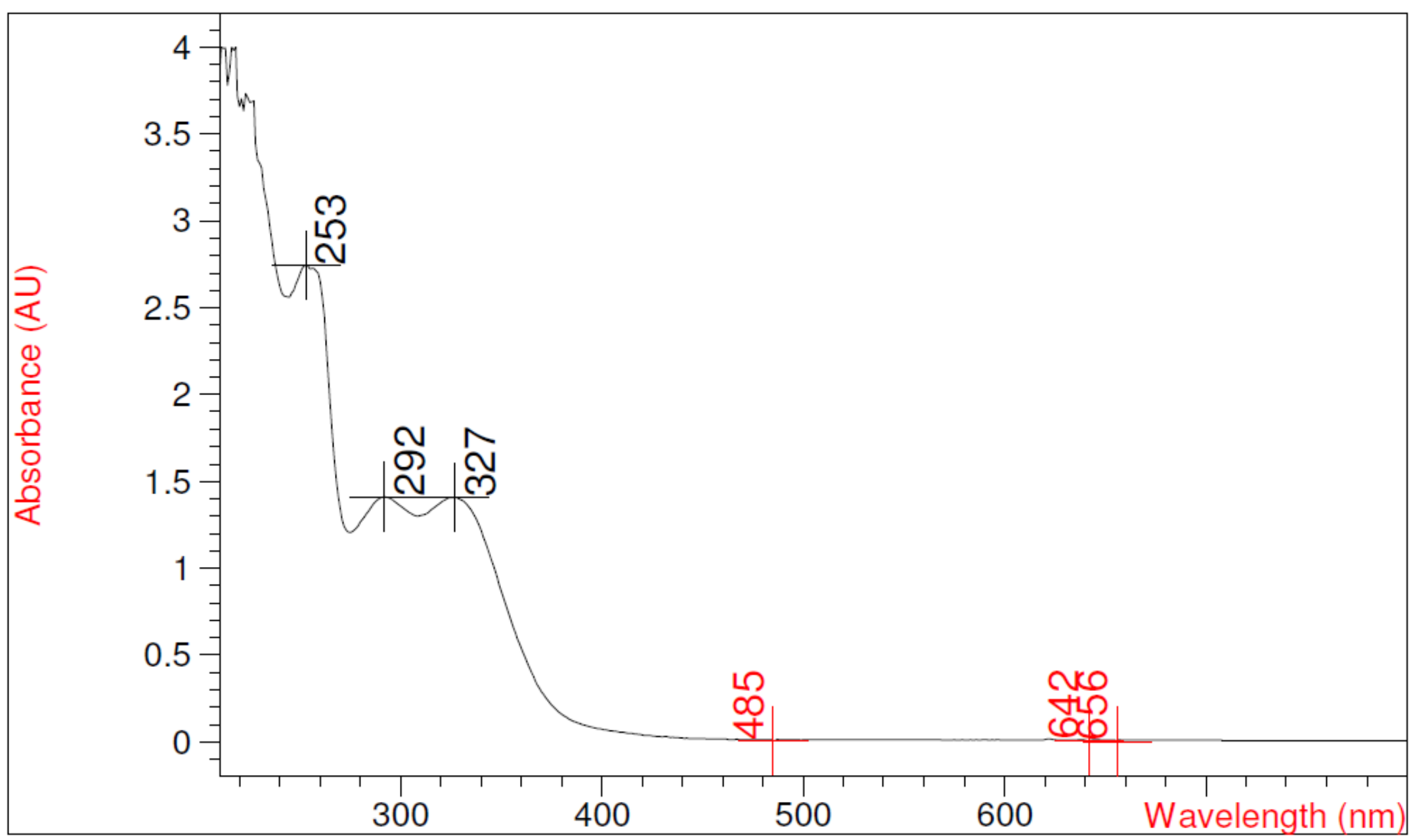

Figure S22. Ultraviolet (UV) spectrum of compound 3. 


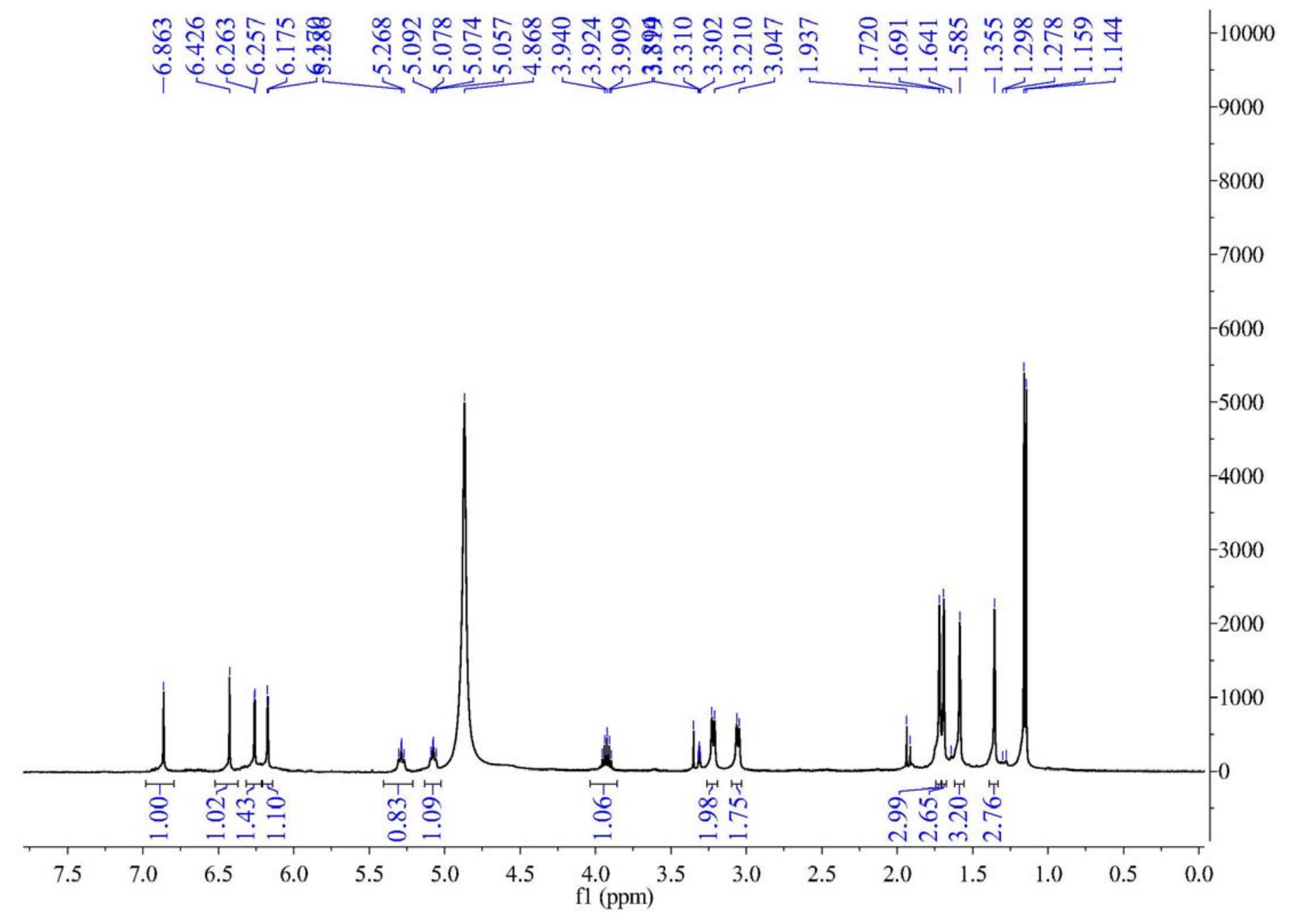

Figure S23. ${ }^{1} \mathrm{H}$ NMR spectrum of compound 3 (400 MHz, $\left.\mathrm{CD}_{3} \mathrm{OD}\right)$. 


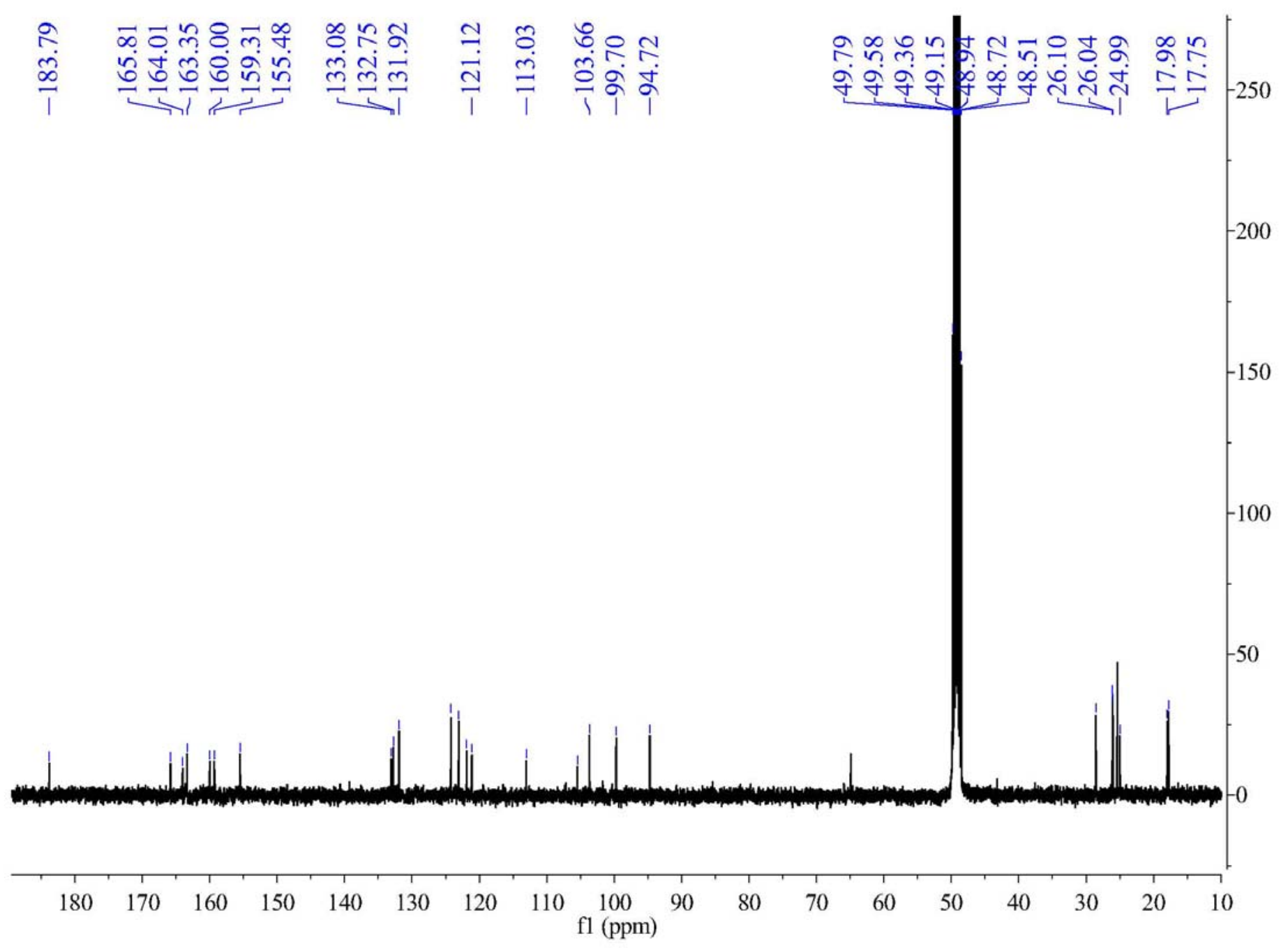

Figure S24. ${ }^{13} \mathrm{C}$ NMR spectrum of compound 3 (100MHz, $\left.\mathrm{CD}_{3} \mathrm{OD}\right)$. 


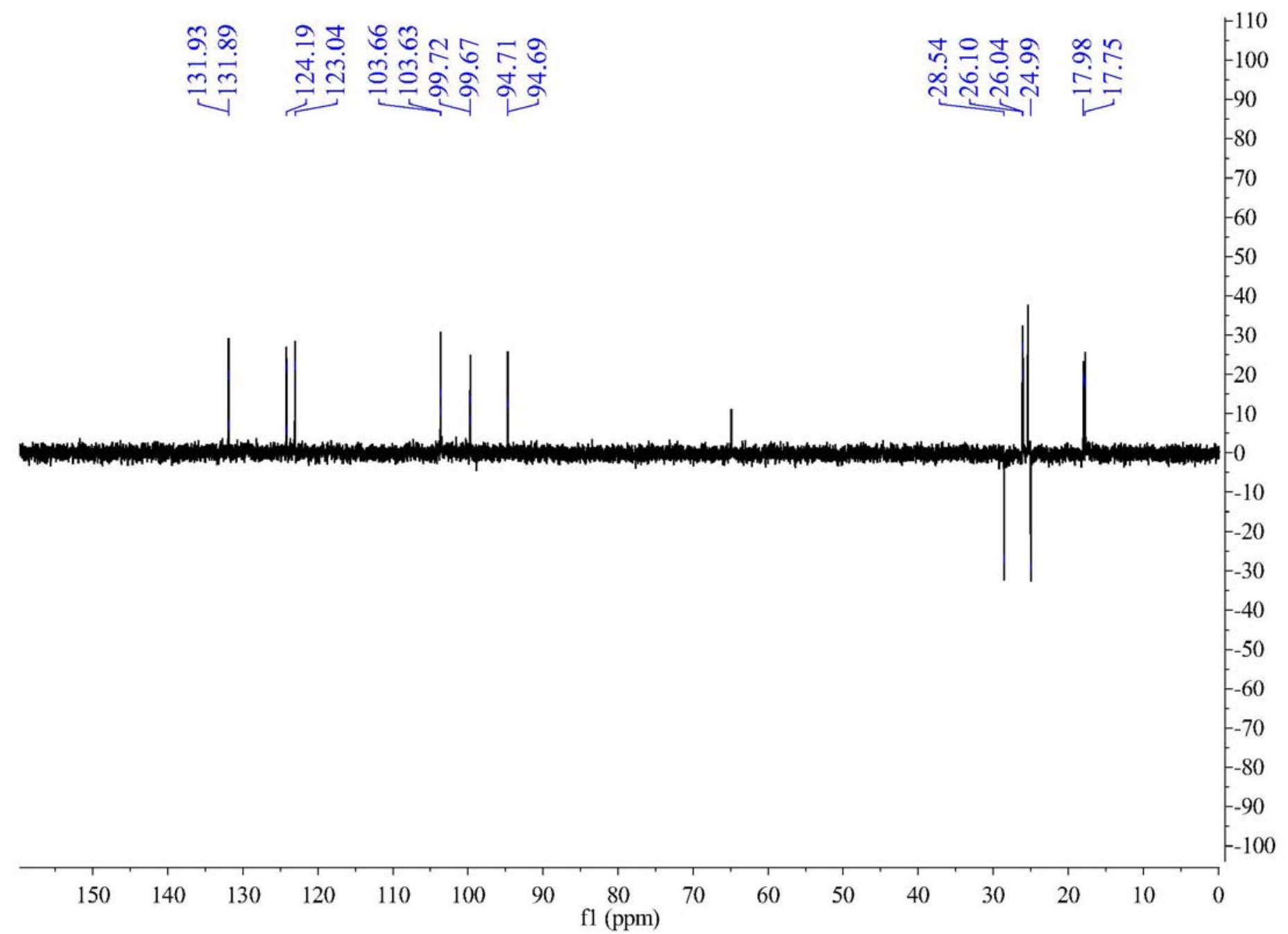

Figure S25. DEPT 135 spectrum of compound 3 (100MHz, $\left.\mathrm{CD}_{3} \mathrm{OD}\right)$. 


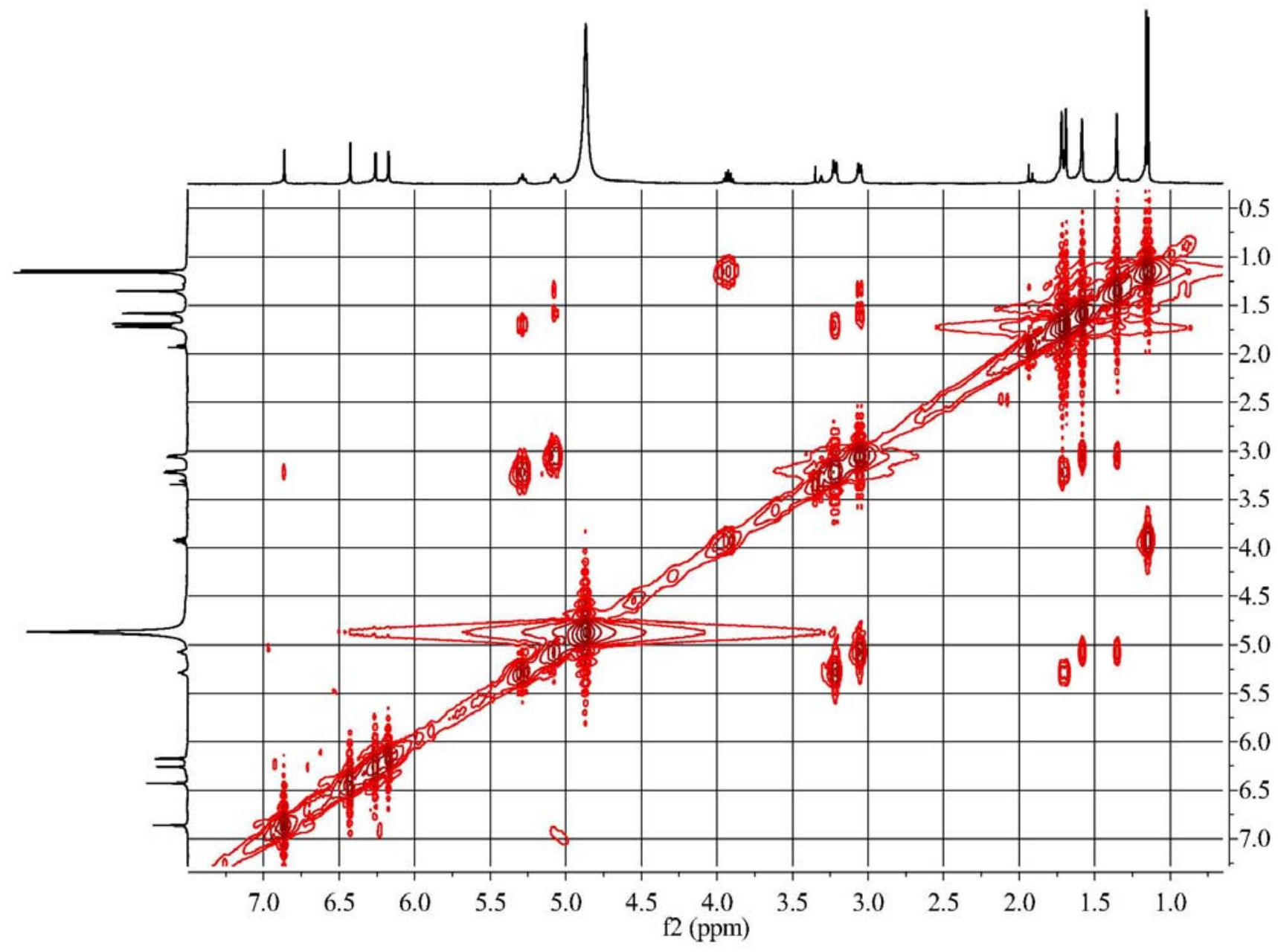

Figure S26. ${ }^{1} \mathrm{H}-{ }^{1} \mathrm{H}$ COSY spectrum of compound 3 (400 MHz, $\mathrm{CD}_{3} \mathrm{OD}$ ). 


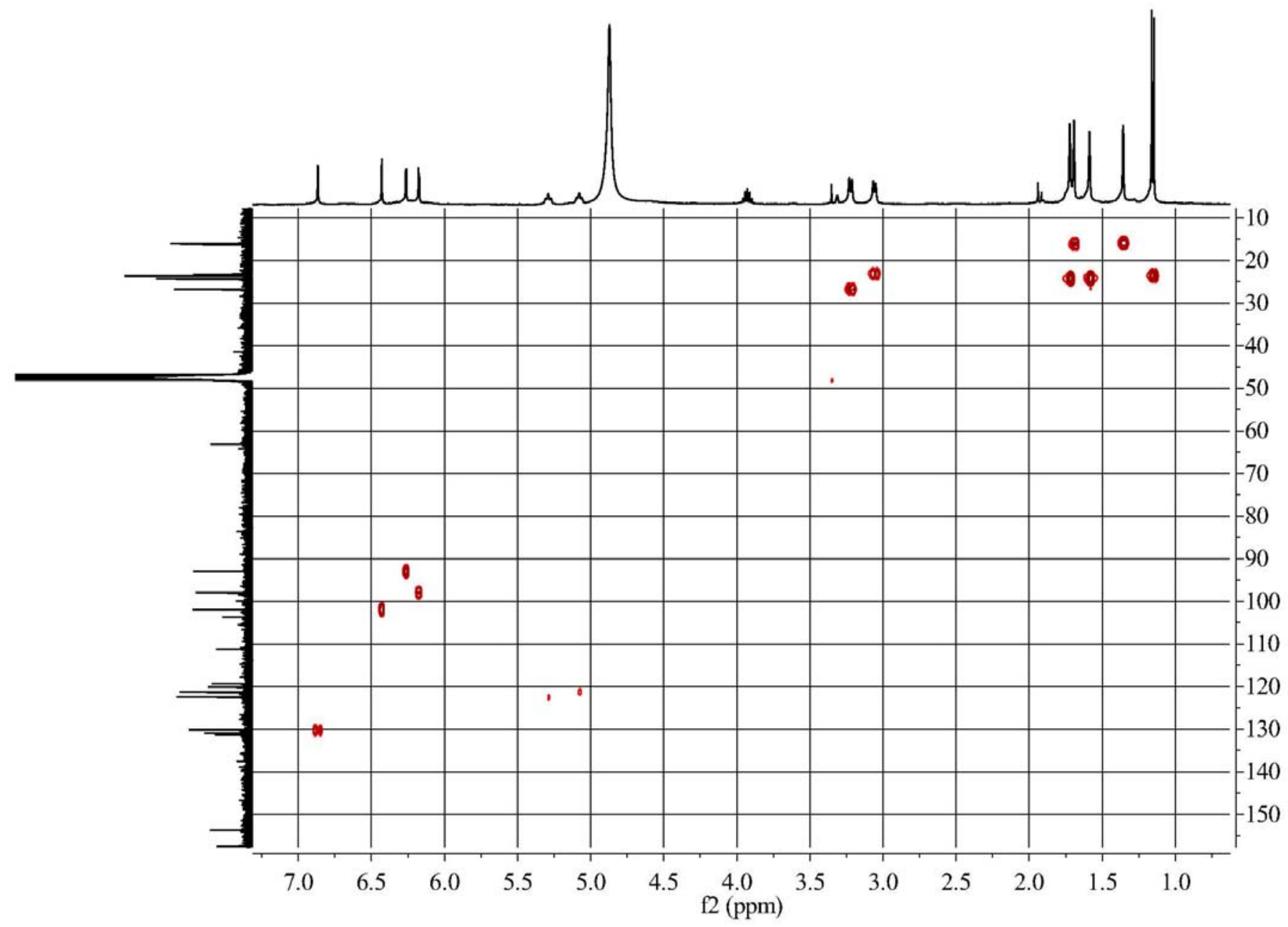

Figure S27. HSQC spectrum of compound 3 (400 and $100 \mathrm{MHz}, \mathrm{CD}_{3} \mathrm{OD}$ ). 


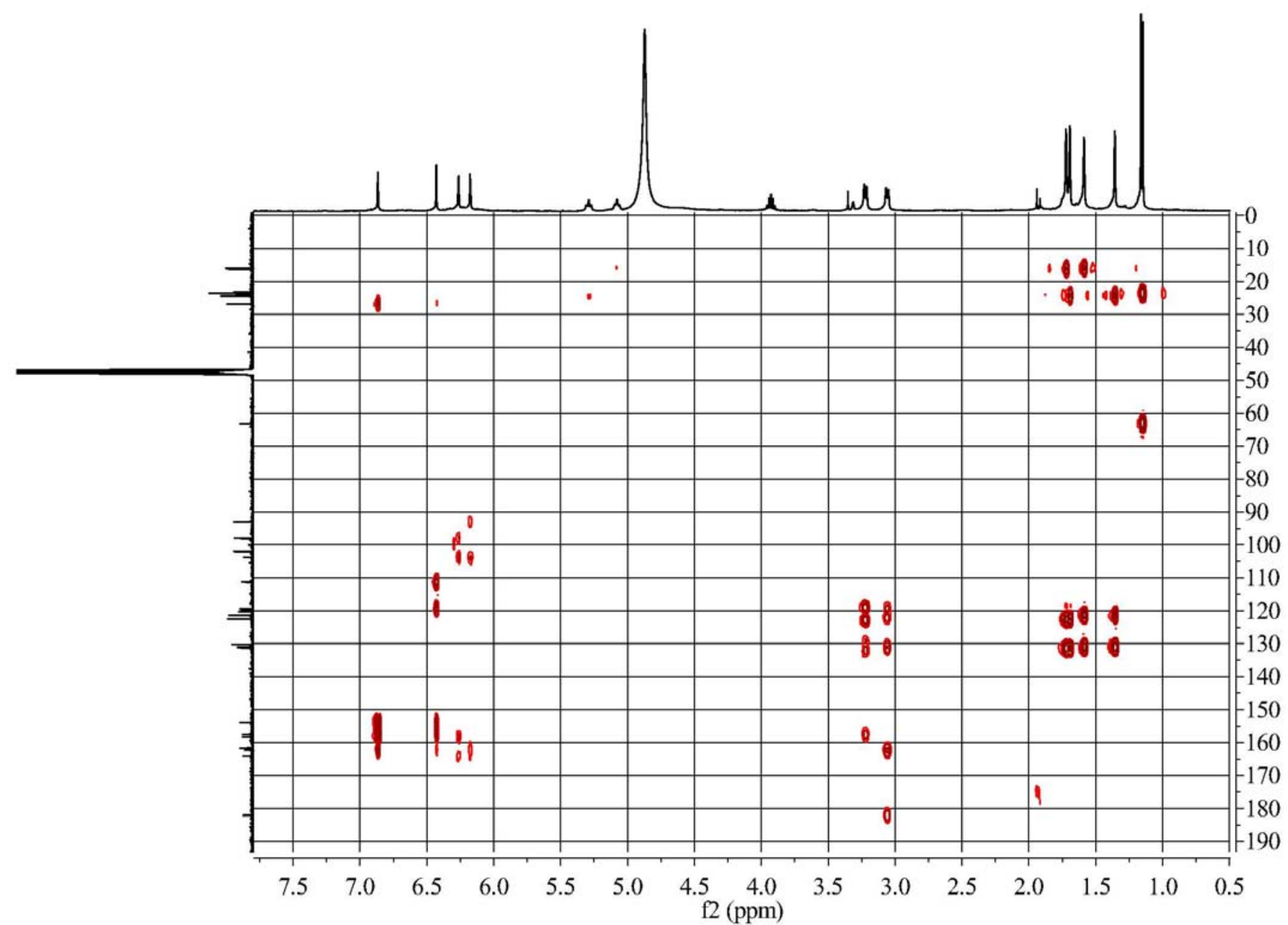

Figure S28. HMBC spectrum of compound 3 (400 and $100 \mathrm{MHz}, \mathrm{CD}_{3} \mathrm{OD}$ ). 

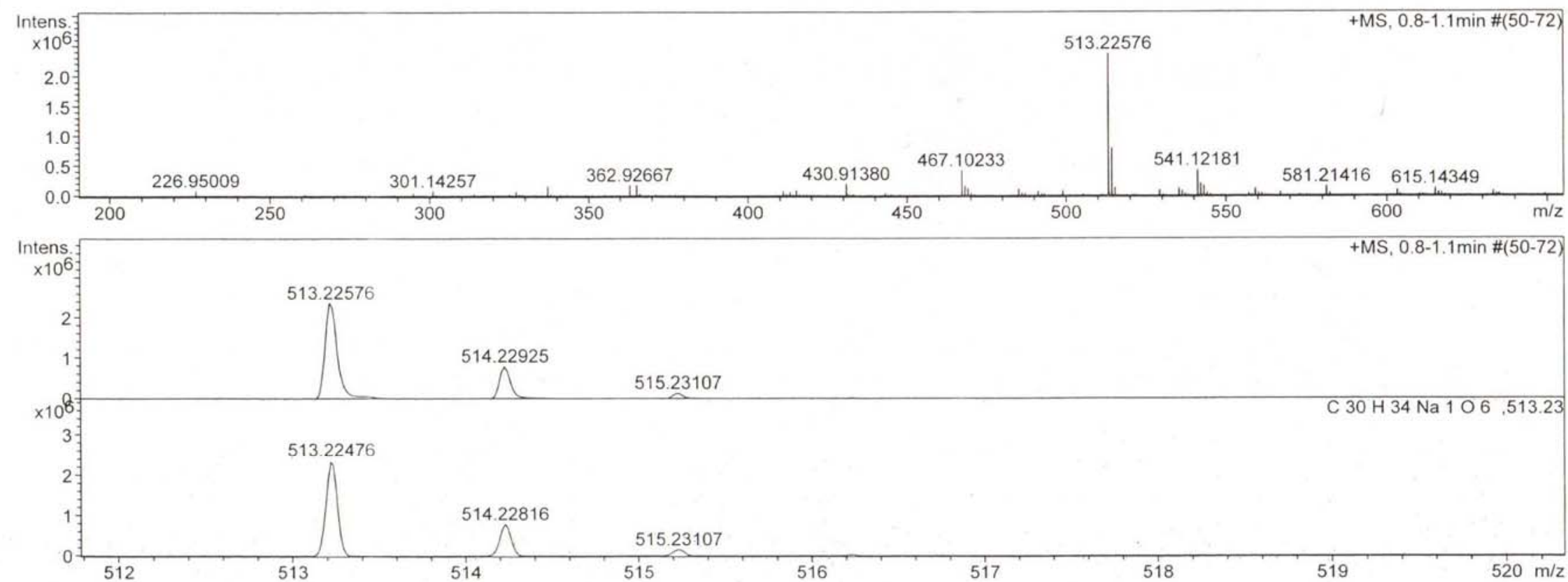

Figure S29. Positive HRESIMS spectrum of compound 4. 


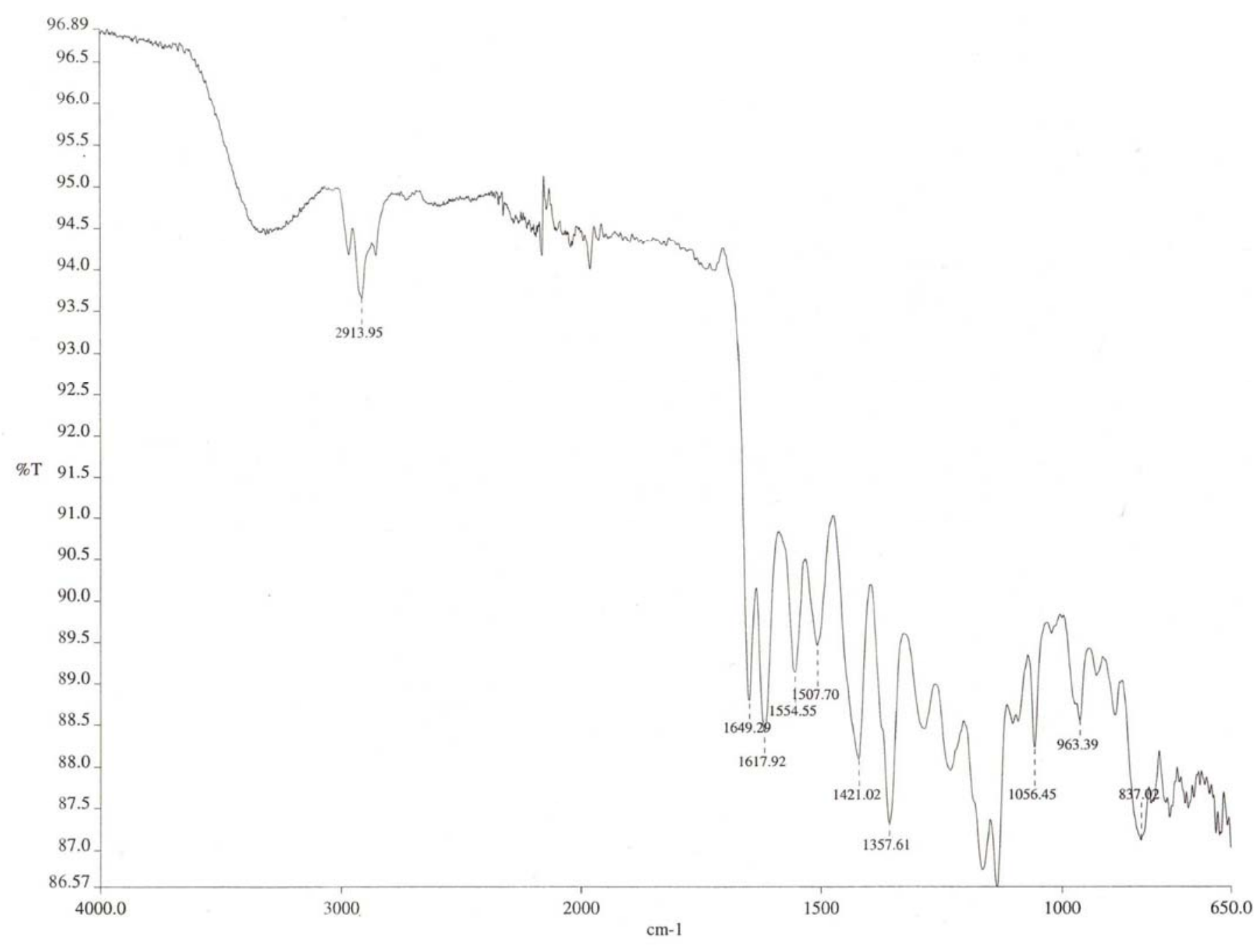

Figure S30. Infrared (IR) spectrum of compound 4. 


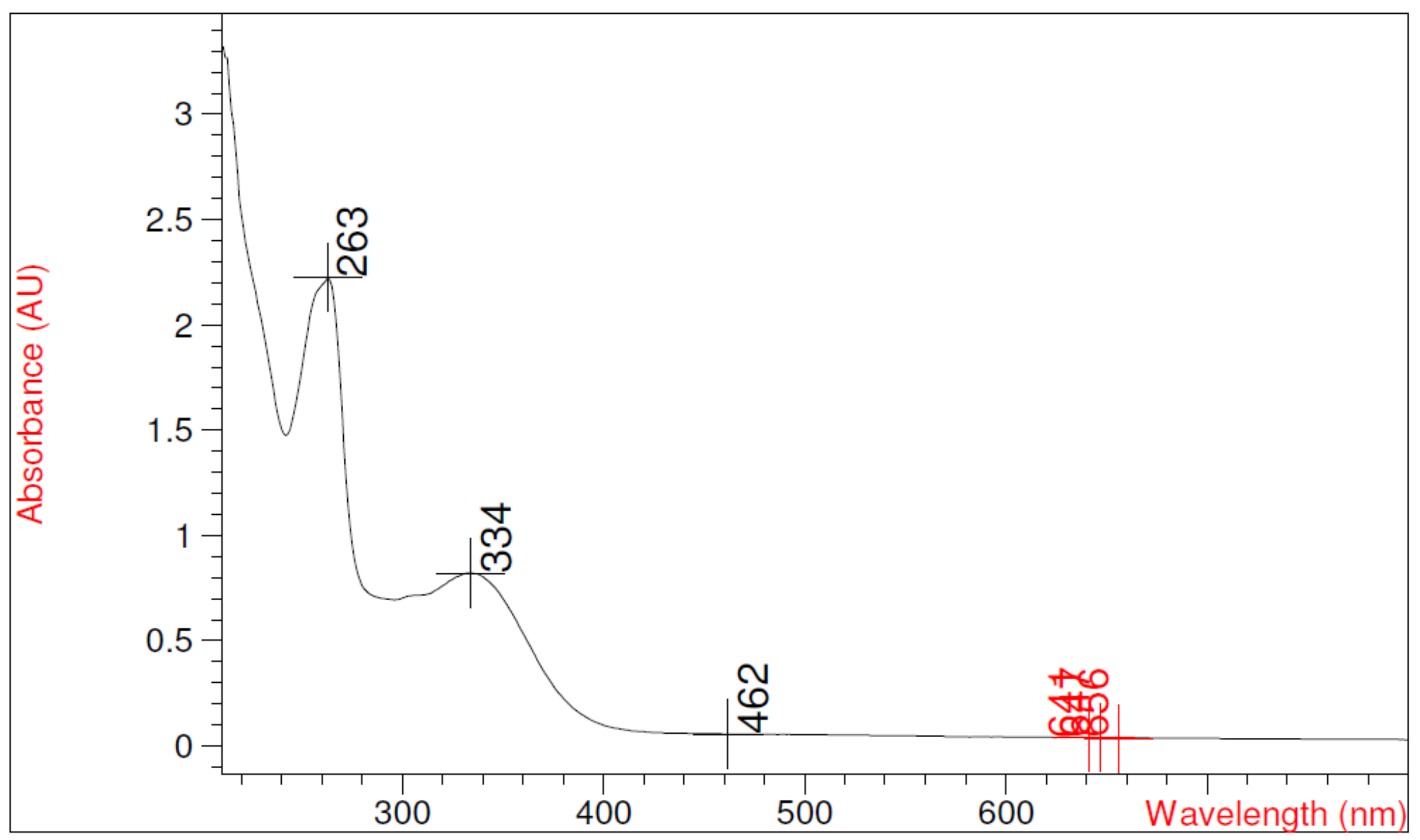

Figure S31. Ultraviolet (UV) spectrum of compound 4.

35 


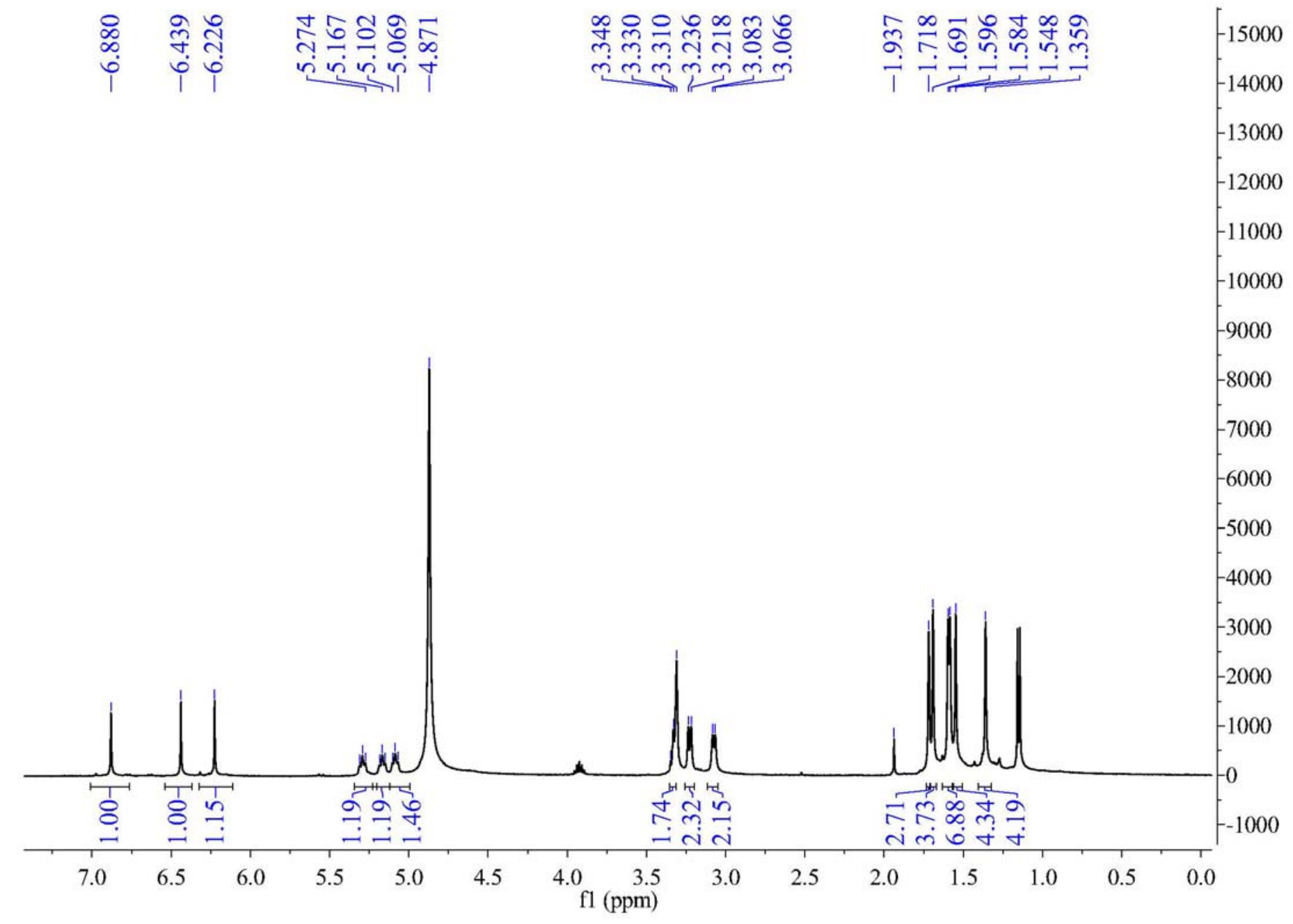

Figure S32. ${ }^{1} \mathrm{H}$ NMR spectrum of compound 4 (400 MHz, $\left.\mathrm{CD}_{3} \mathrm{OD}\right)$. 

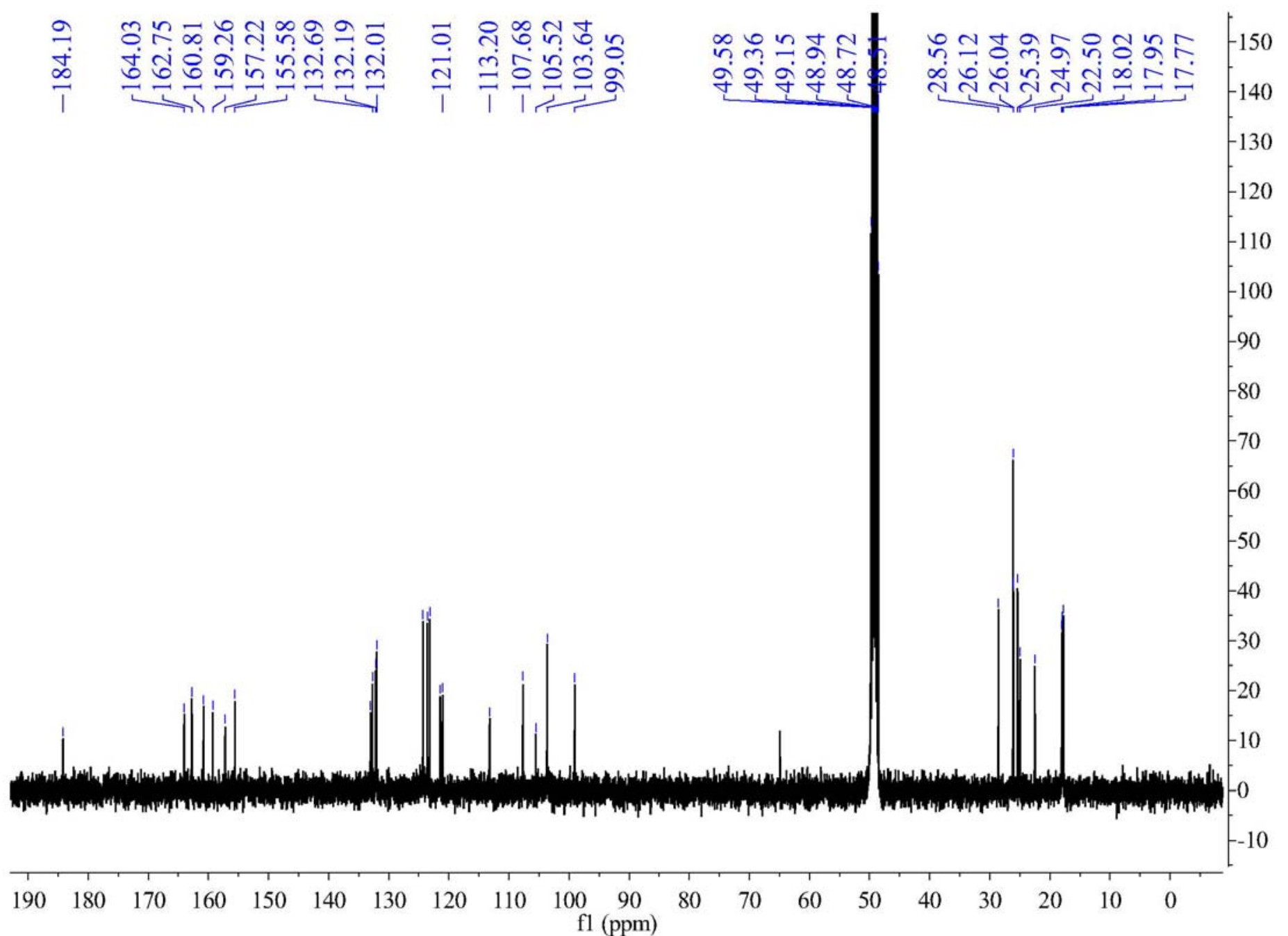

Figure S33. ${ }^{13} \mathrm{C}$ NMR spectrum of compound 4 (100MHz, $\left.\mathrm{CD}_{3} \mathrm{OD}\right)$. 


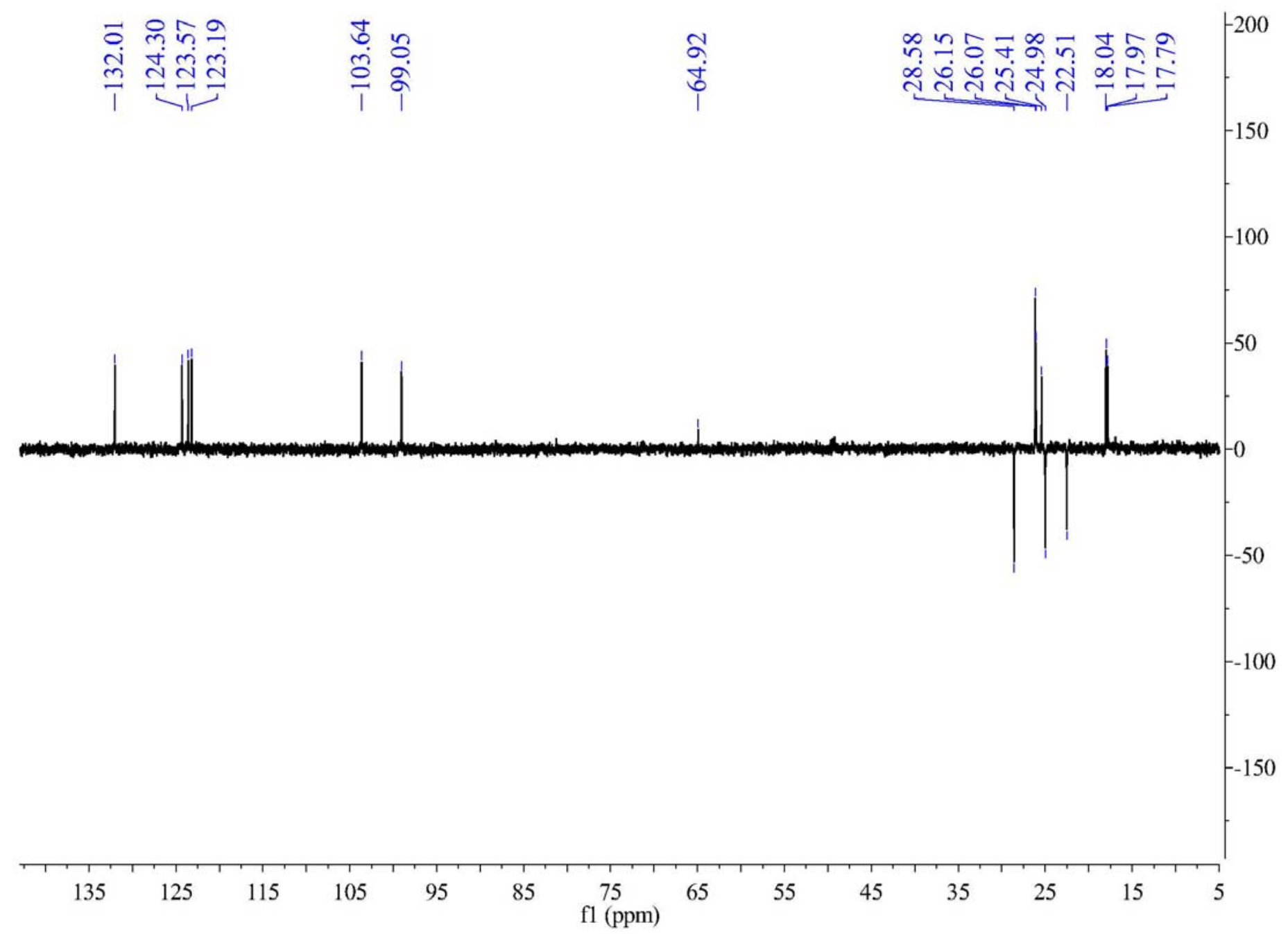

Figure S34. DEPT 135 spectrum of compound 4 (100MHz, $\left.\mathrm{CD}_{3} \mathrm{OD}\right)$. 


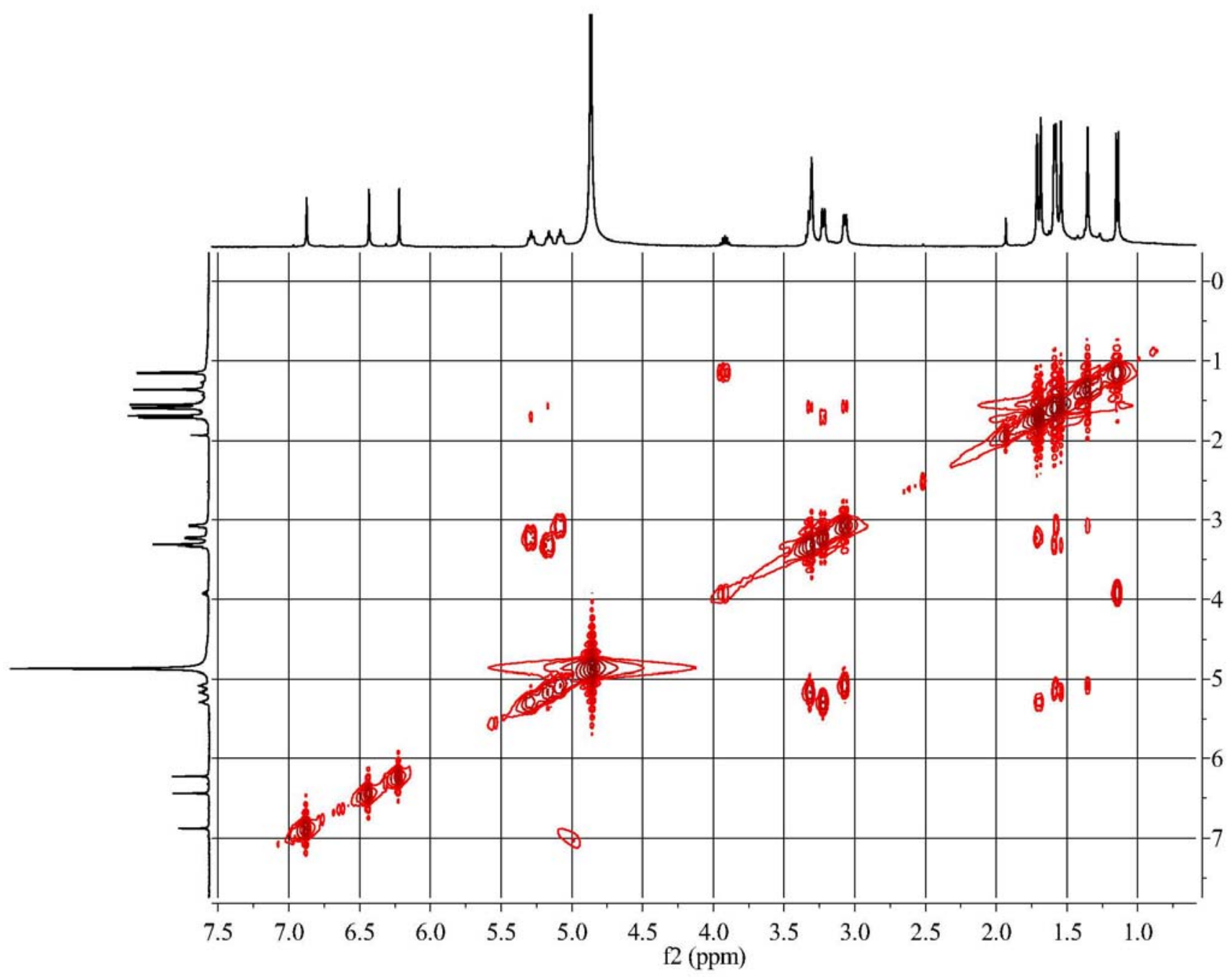

Figure S35. ${ }^{1} \mathrm{H}-{ }^{1} \mathrm{H}$ COSY spectrum of compound 4 (400 MHz, $\left.\mathrm{CD}_{3} \mathrm{OD}\right)$. 


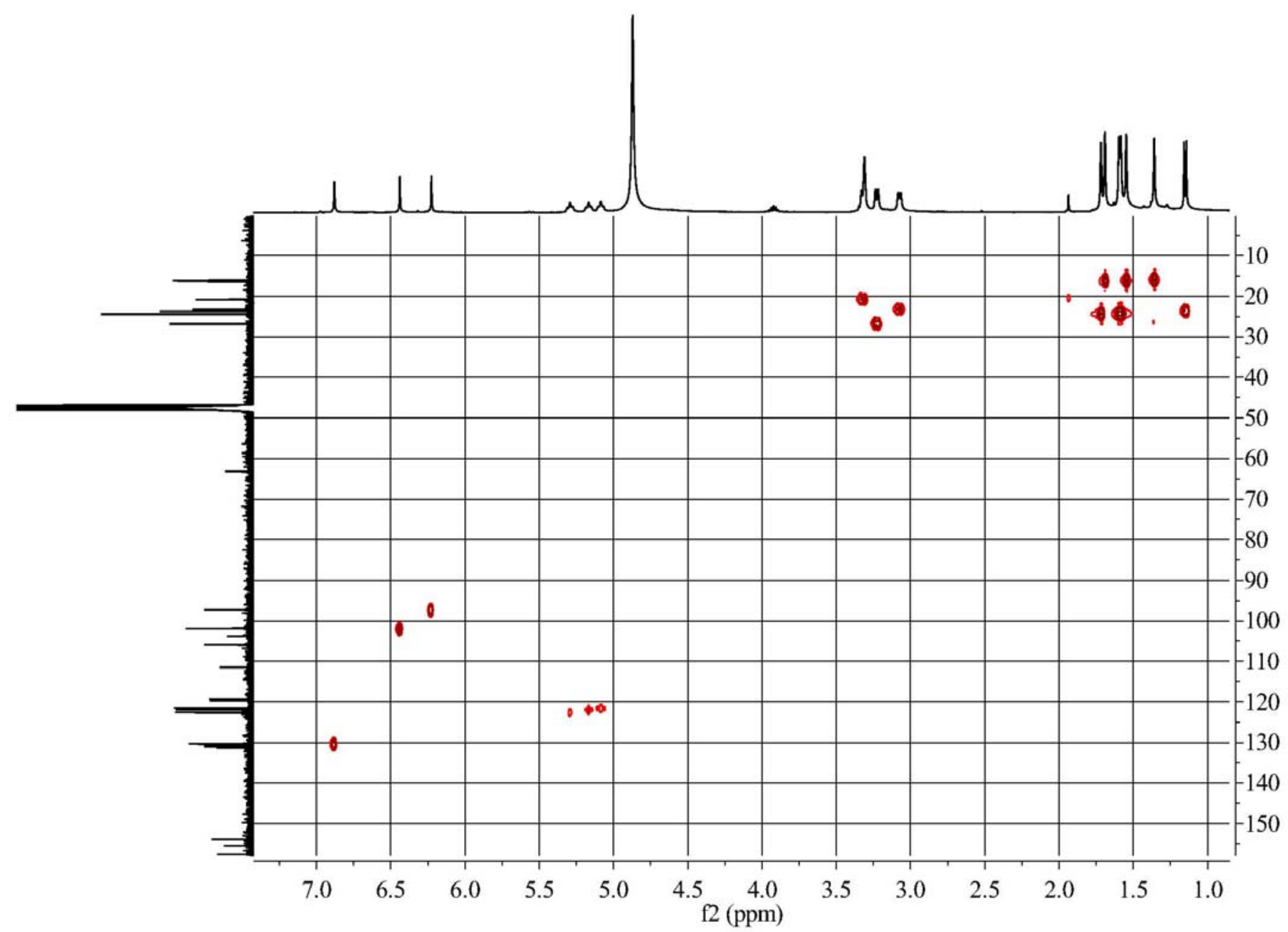

Figure S36. HSQC spectrum of compound 4 (400 and $100 \mathrm{MHz}, \mathrm{CD}_{3} \mathrm{OD}$ ). 


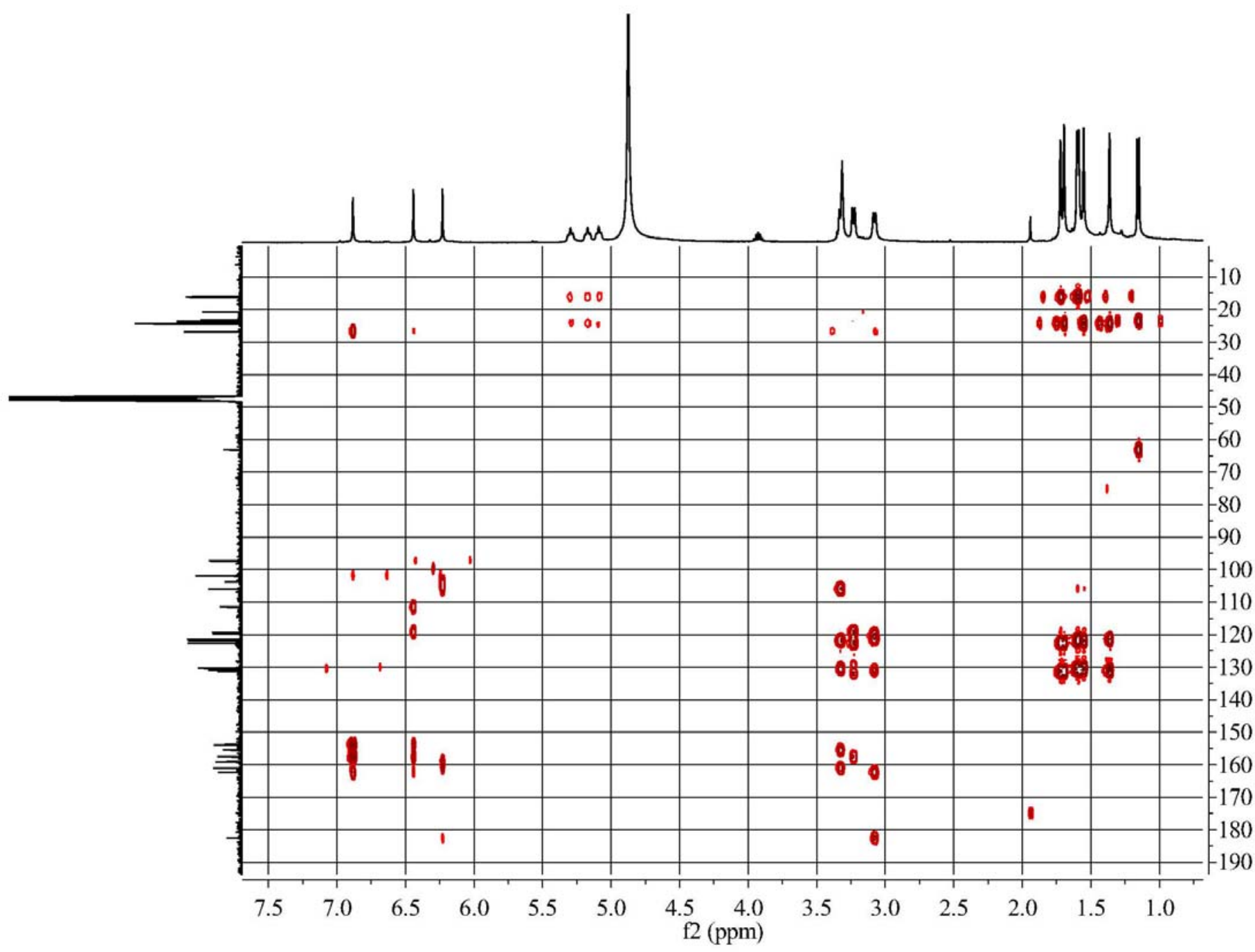

Figure S37. HMBC spectrum of compound 4 (400 and $100 \mathrm{MHz}, \mathrm{CD}_{3} \mathrm{OD}$ ). 

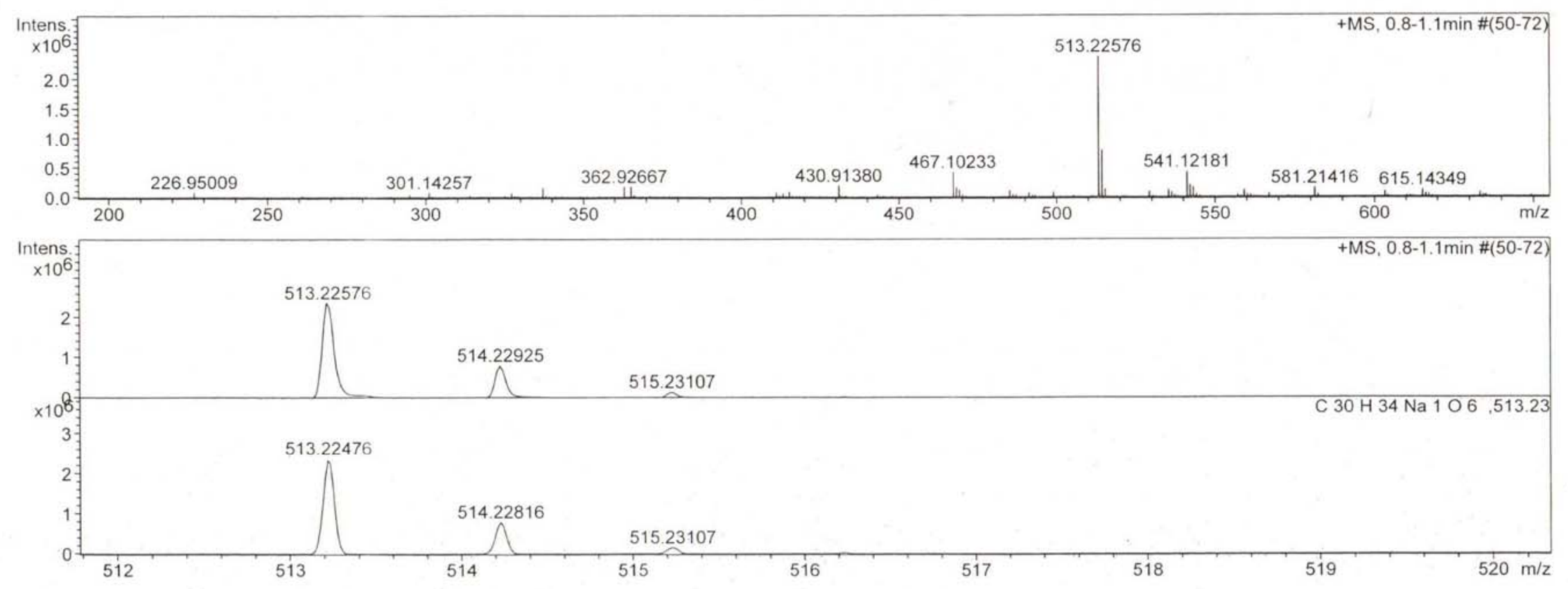

Figure S38. Positive HRESIMS spectrum of compound 5. 


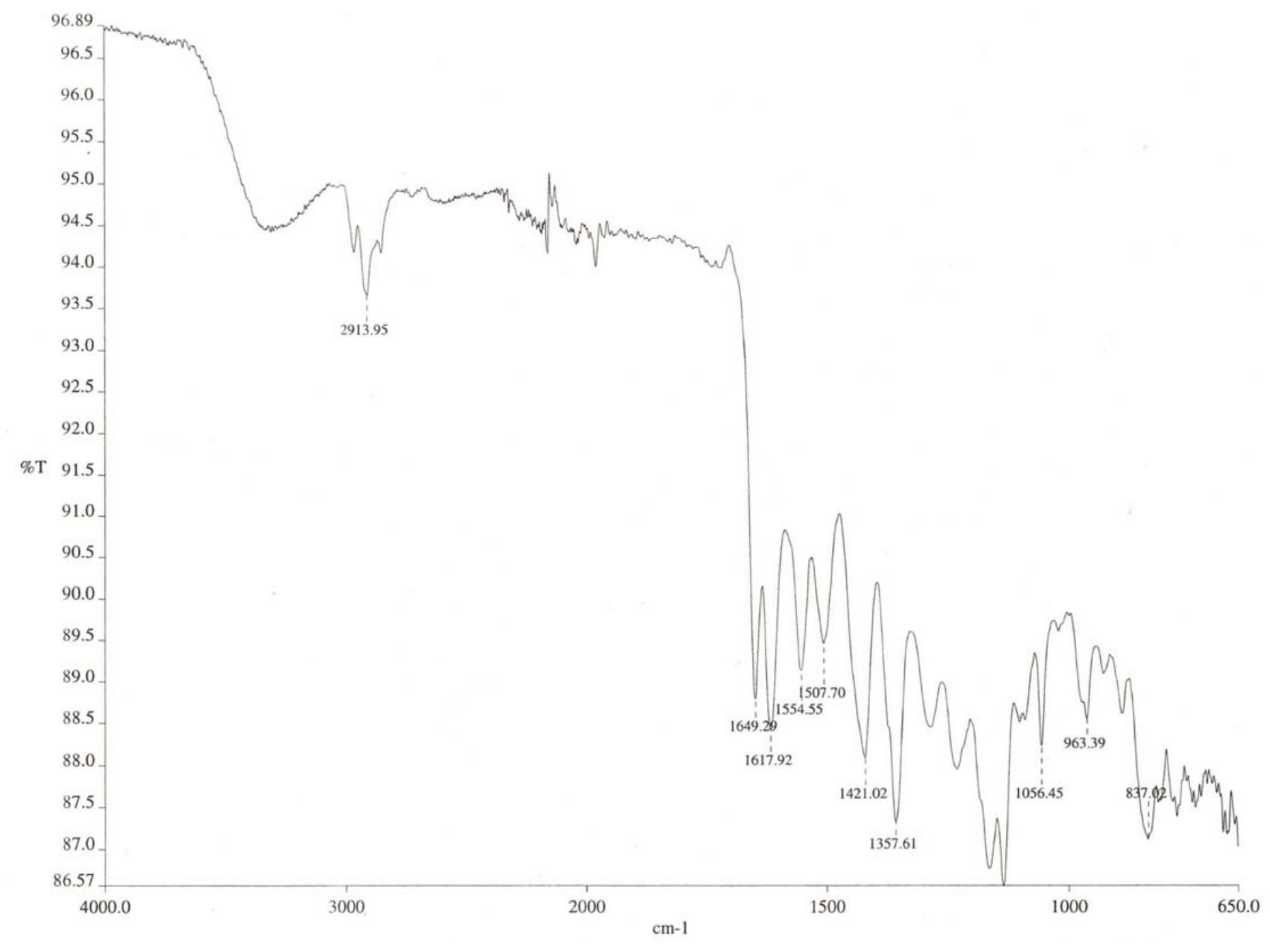

Figure S39. Infrared (IR) spectrum of compound 5. 


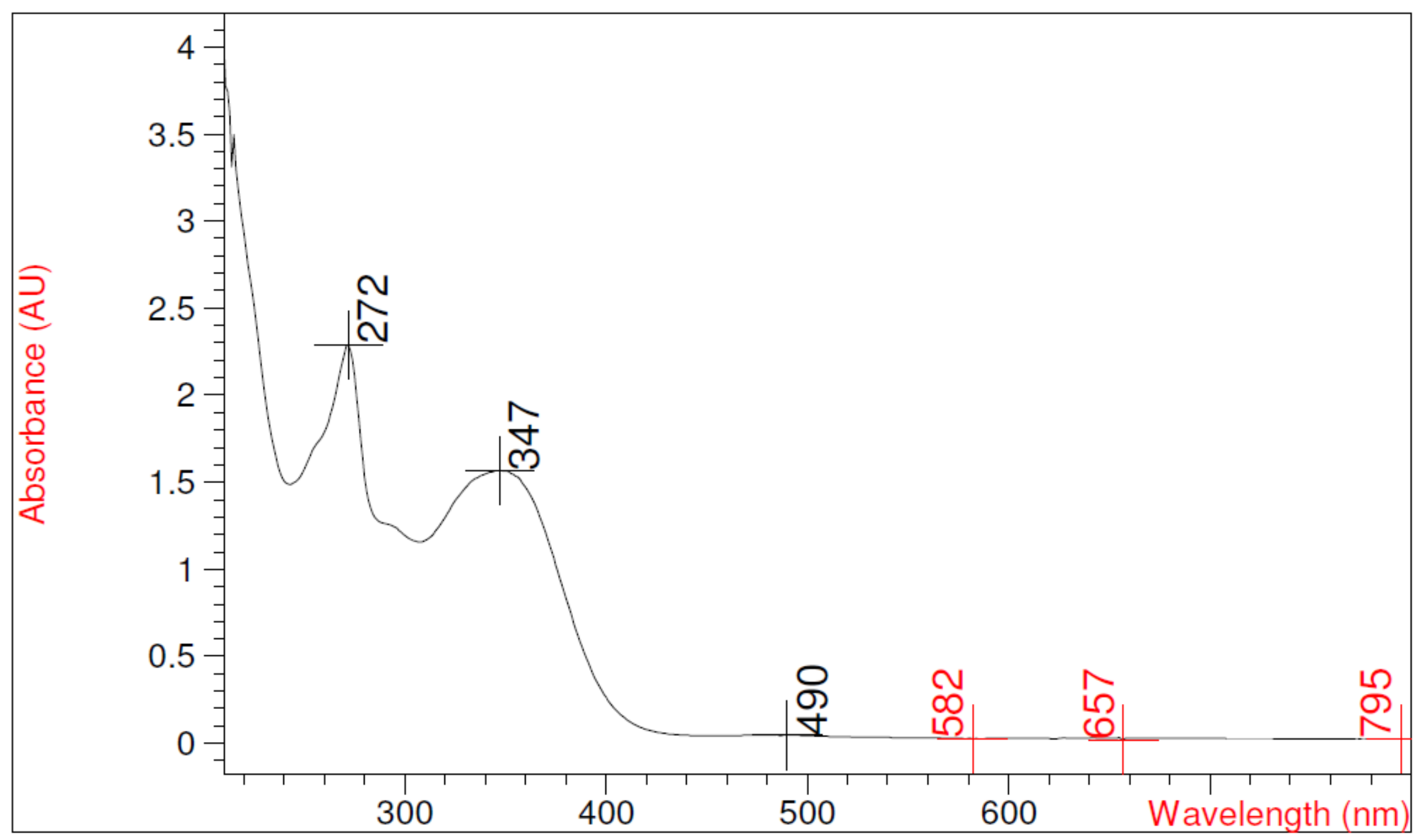

Figure S40. Ultraviolet (UV) spectrum of compound 5. 


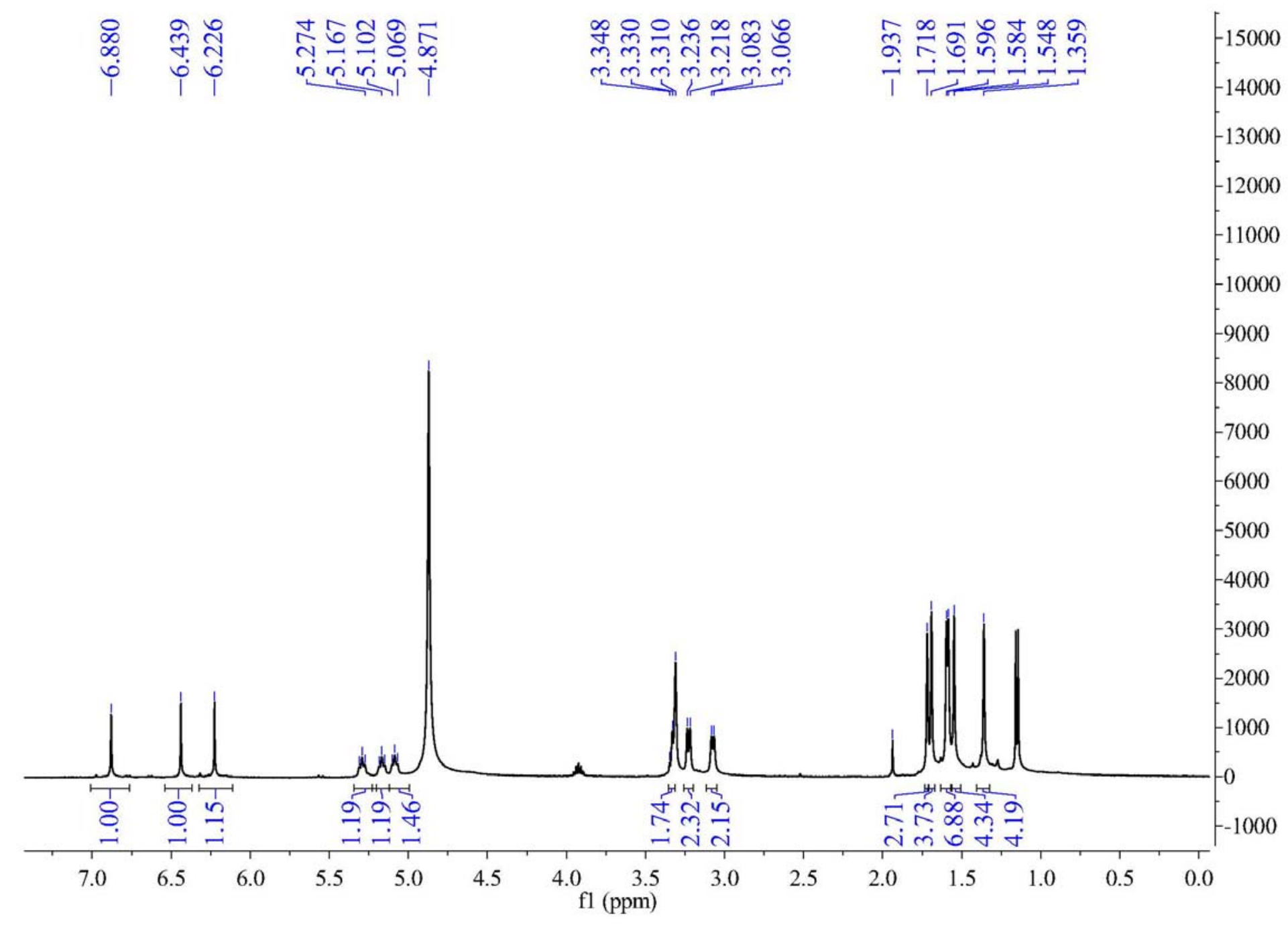

Figure S41. ${ }^{1} \mathrm{H}$ NMR spectrum of compound 5 (400 MHz, $\mathrm{CD}_{3} \mathrm{OD}$ ). 


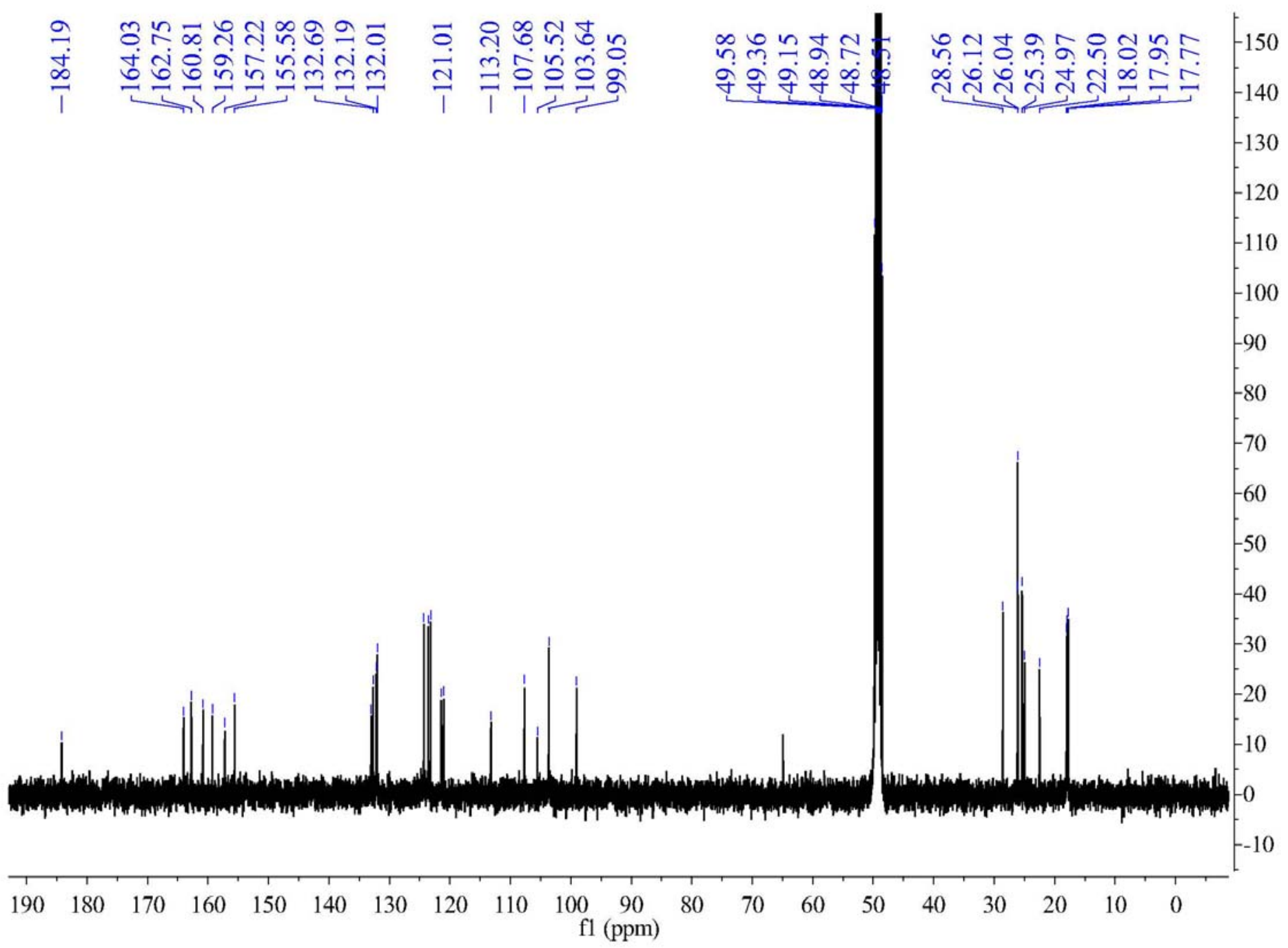

Figure S42. ${ }^{13} \mathrm{C}$ NMR spectrum of compound 5 (100MHz, $\left.\mathrm{CD}_{3} \mathrm{OD}\right)$. 


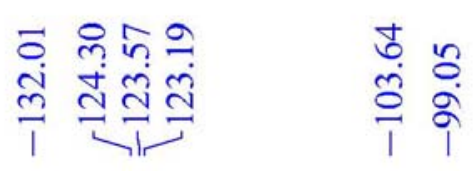

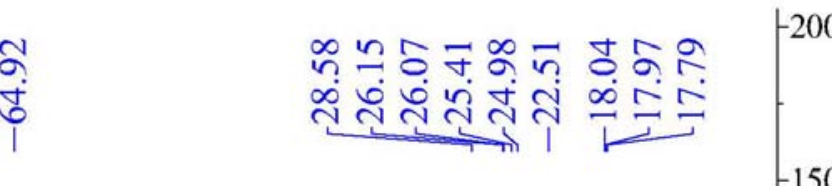

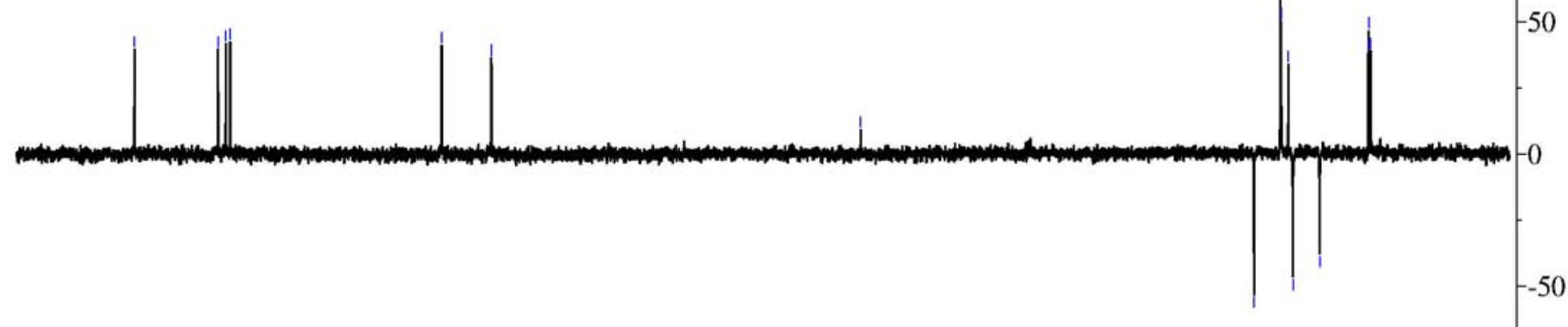

Figure S43. DEPT 135 spectrum of compound 5 (100MHz, CD $\left.{ }_{3} \mathrm{OD}\right)$. 


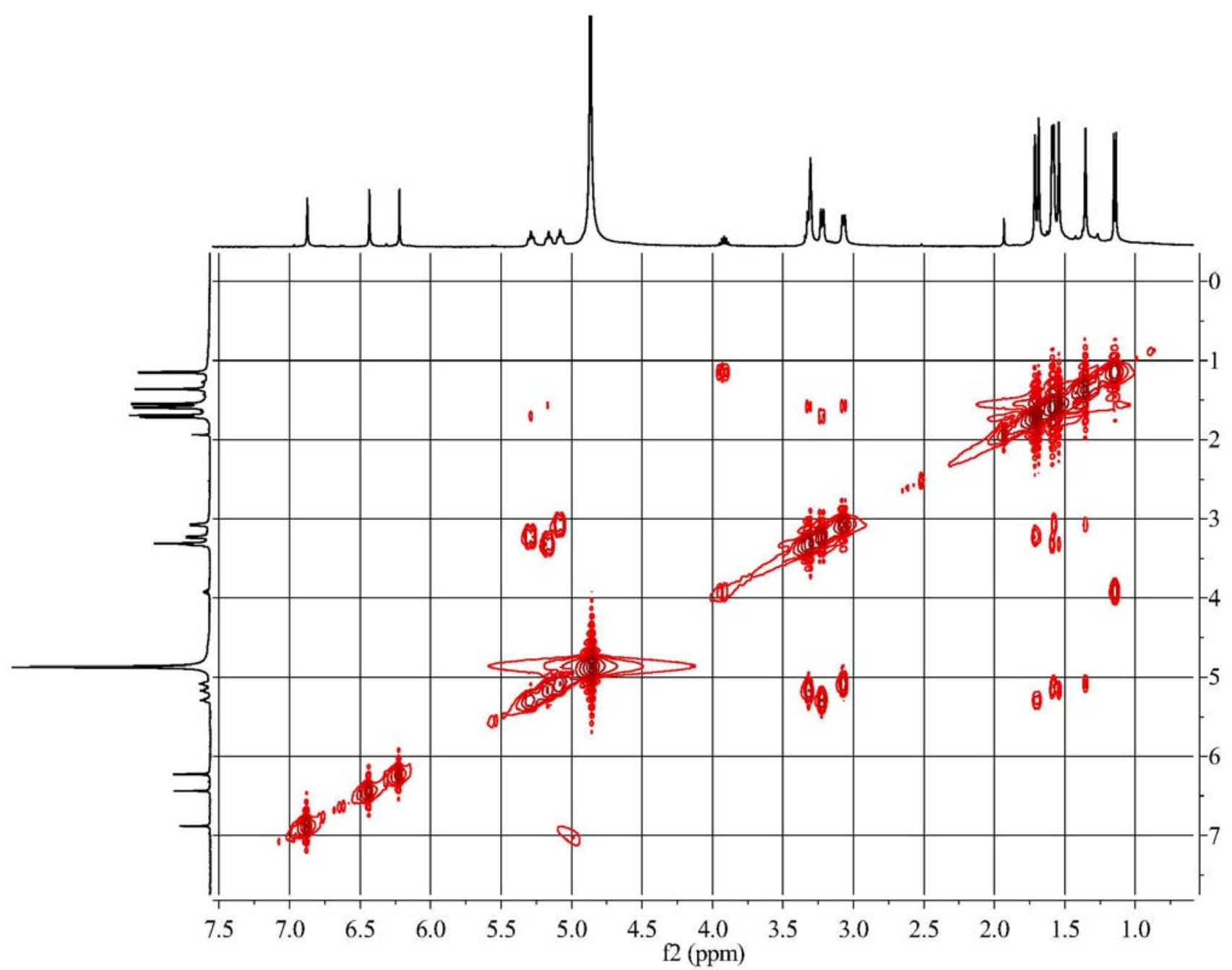

Figure S44. ${ }^{1} \mathrm{H}-{ }^{1} \mathrm{H}$ COSY spectrum of compound 5 (400 MHz, $\mathrm{CD}_{3} \mathrm{OD}$ ). 


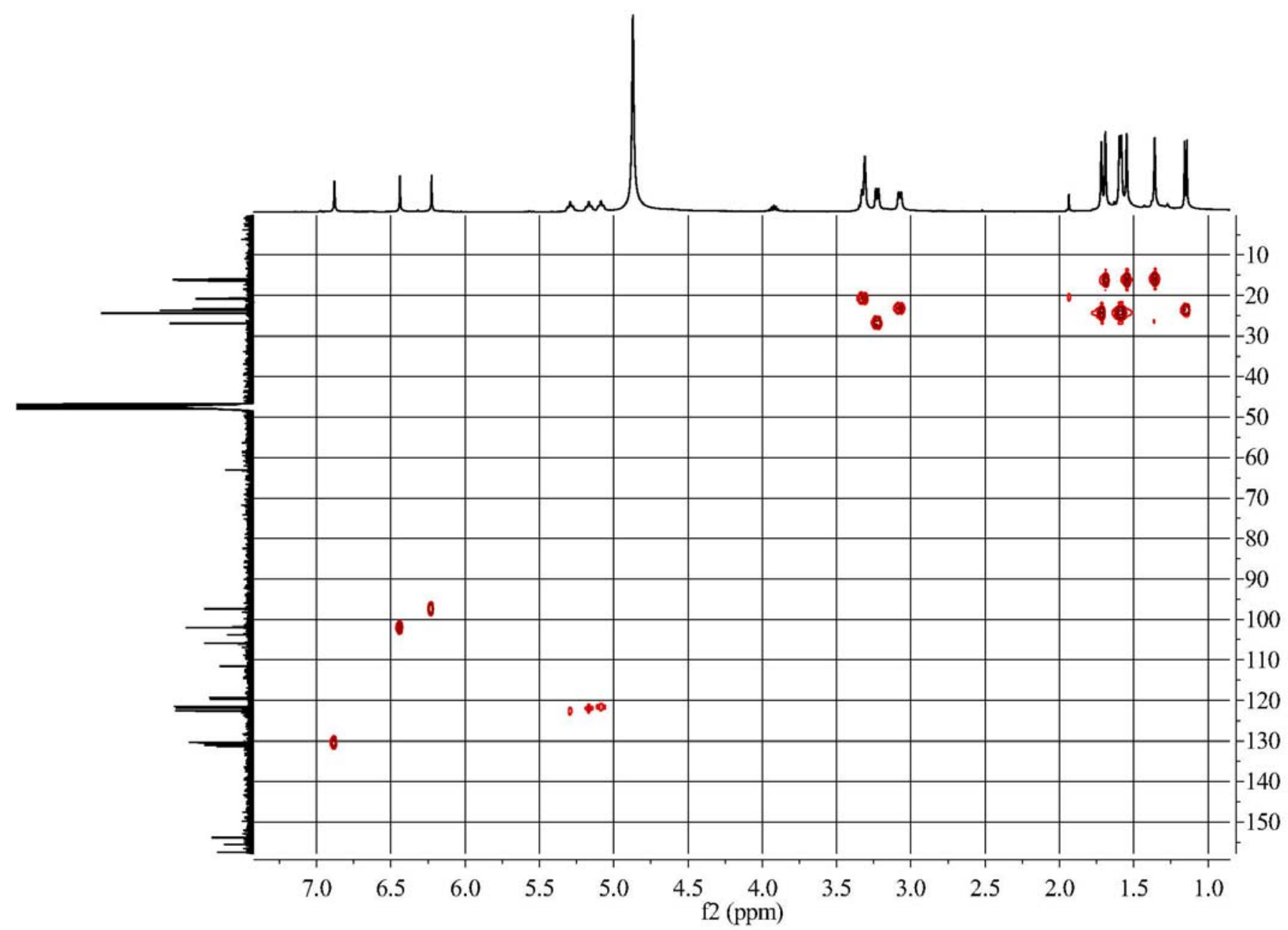

Figure S45. HSQC spectrum of compound 5 (400 and $100 \mathrm{MHz}, \mathrm{CD}_{3} \mathrm{OD}$ ). 


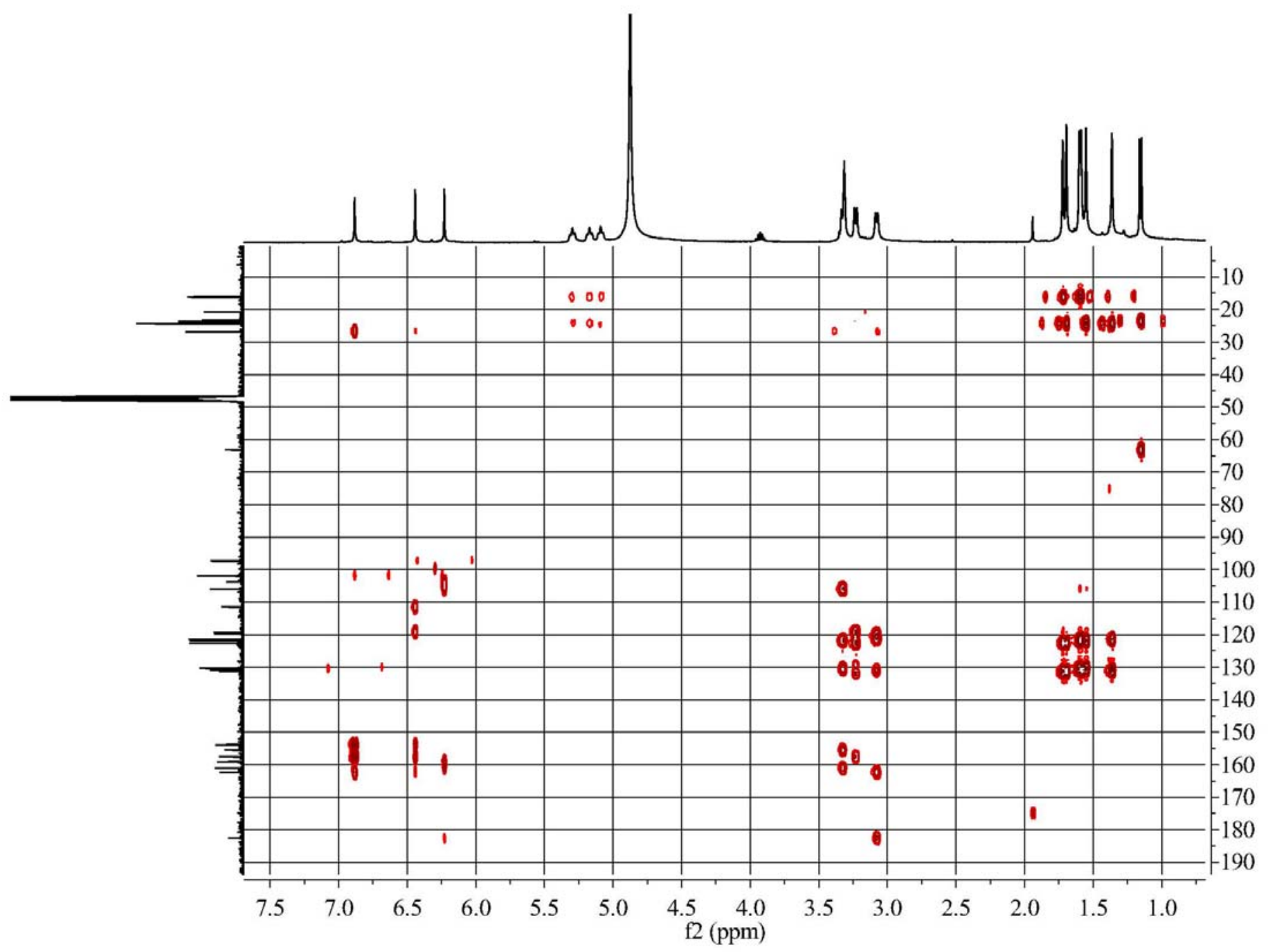

Figure S46. HMBC spectrum of compound 5 (400 and $100 \mathrm{MHz}, \mathrm{CD}_{3} \mathrm{OD}$ ). 


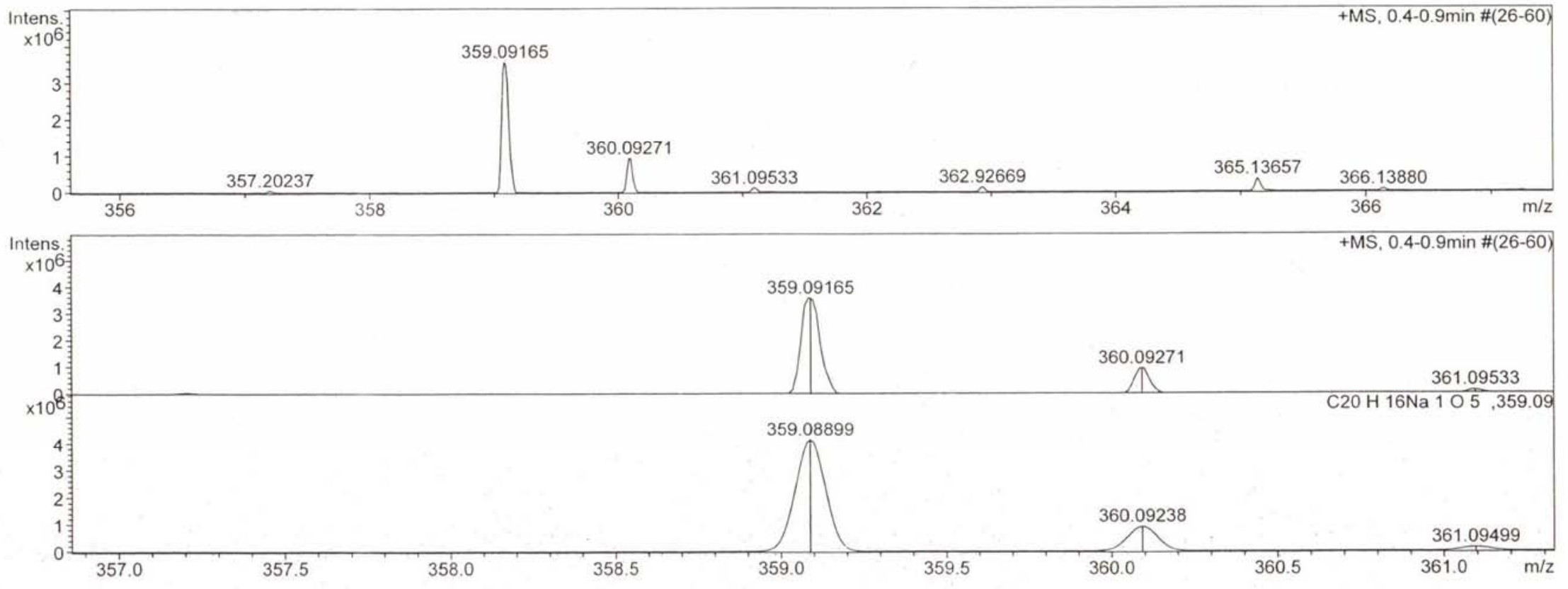

Figure S47. Positive HRESIMS spectrum of compound 6. 


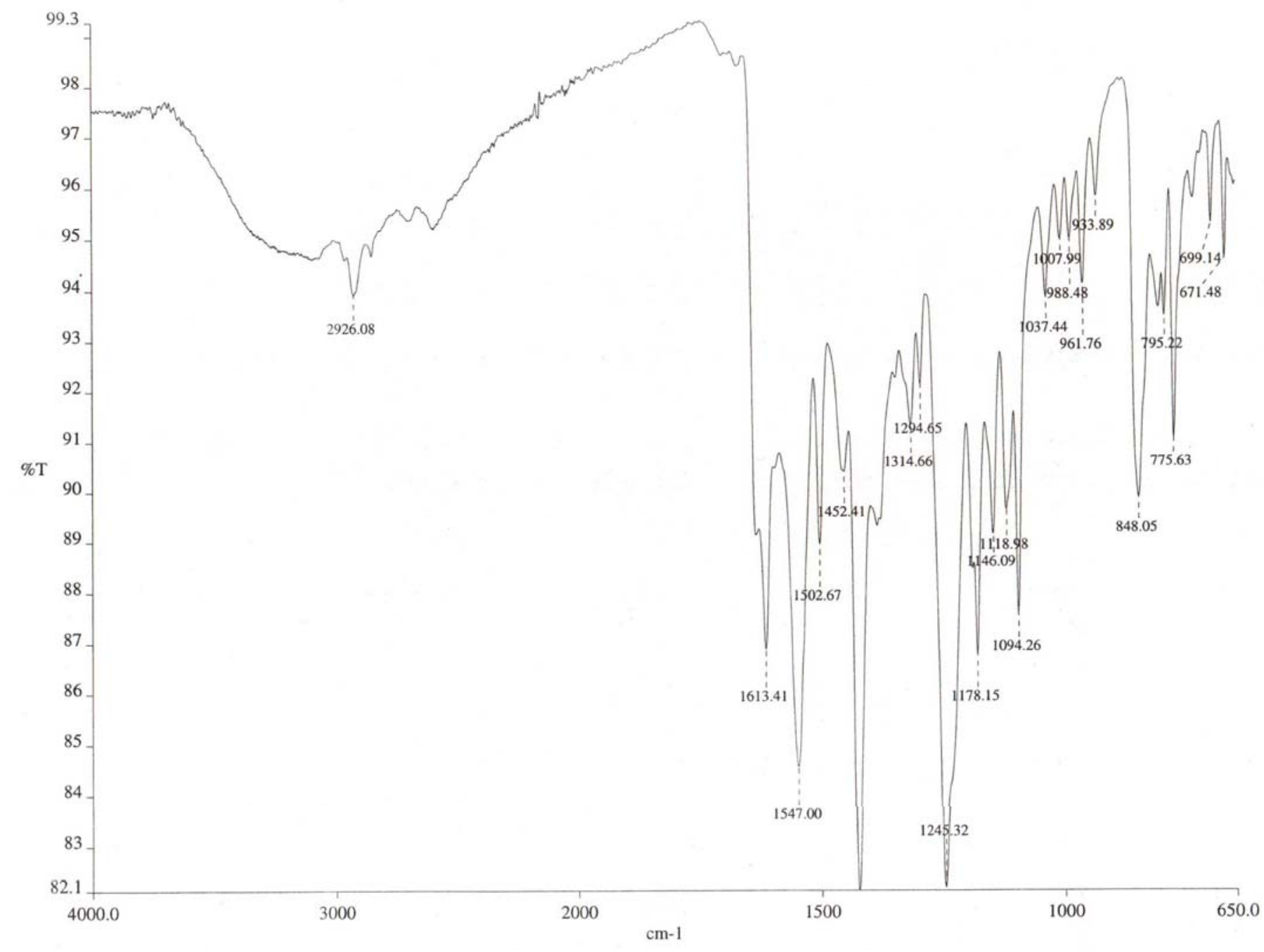

Figure S48. Infrared (IR) spectrum of compound 6 . 


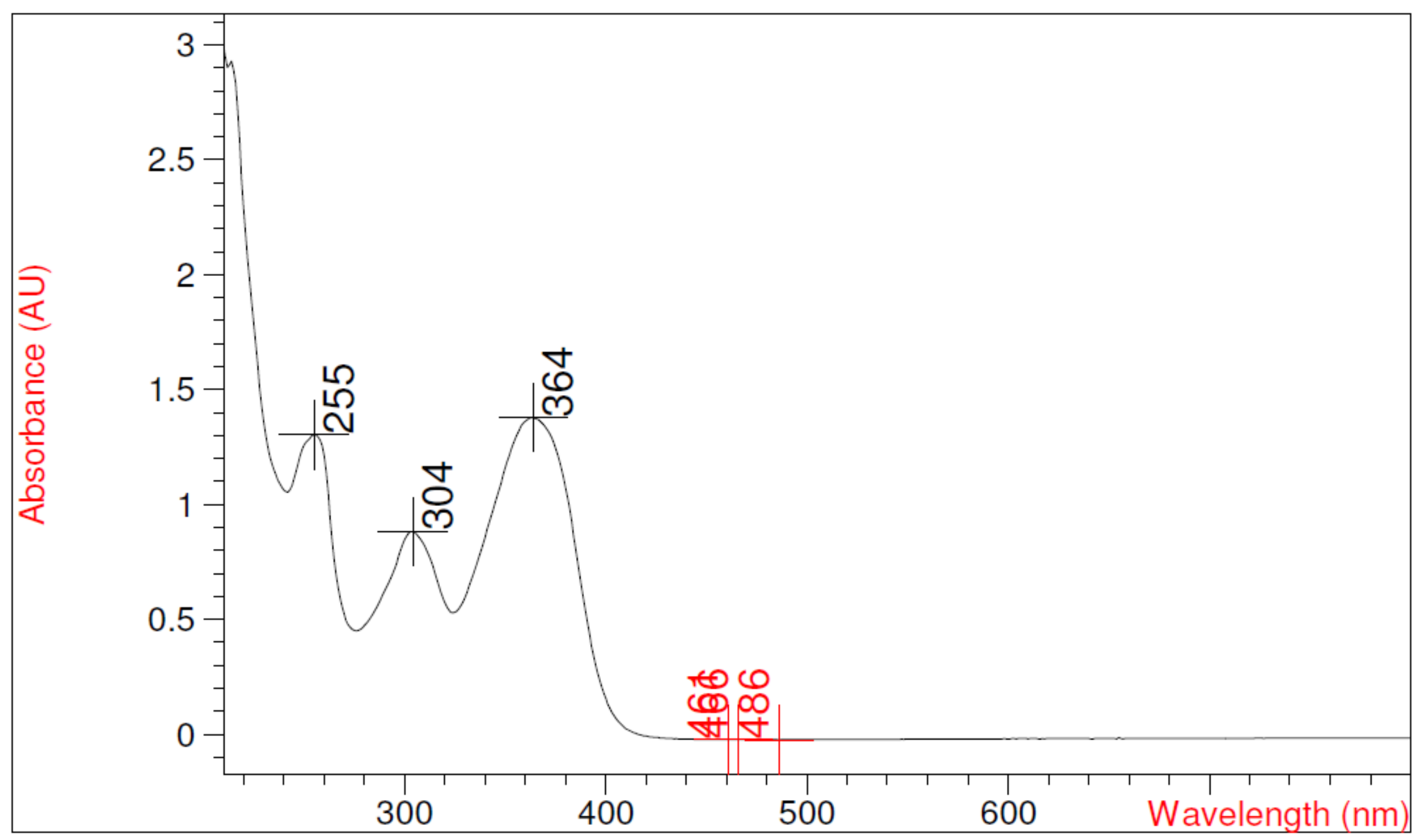

Figure S49. Ultraviolet (UV) spectrum of compound 6. 


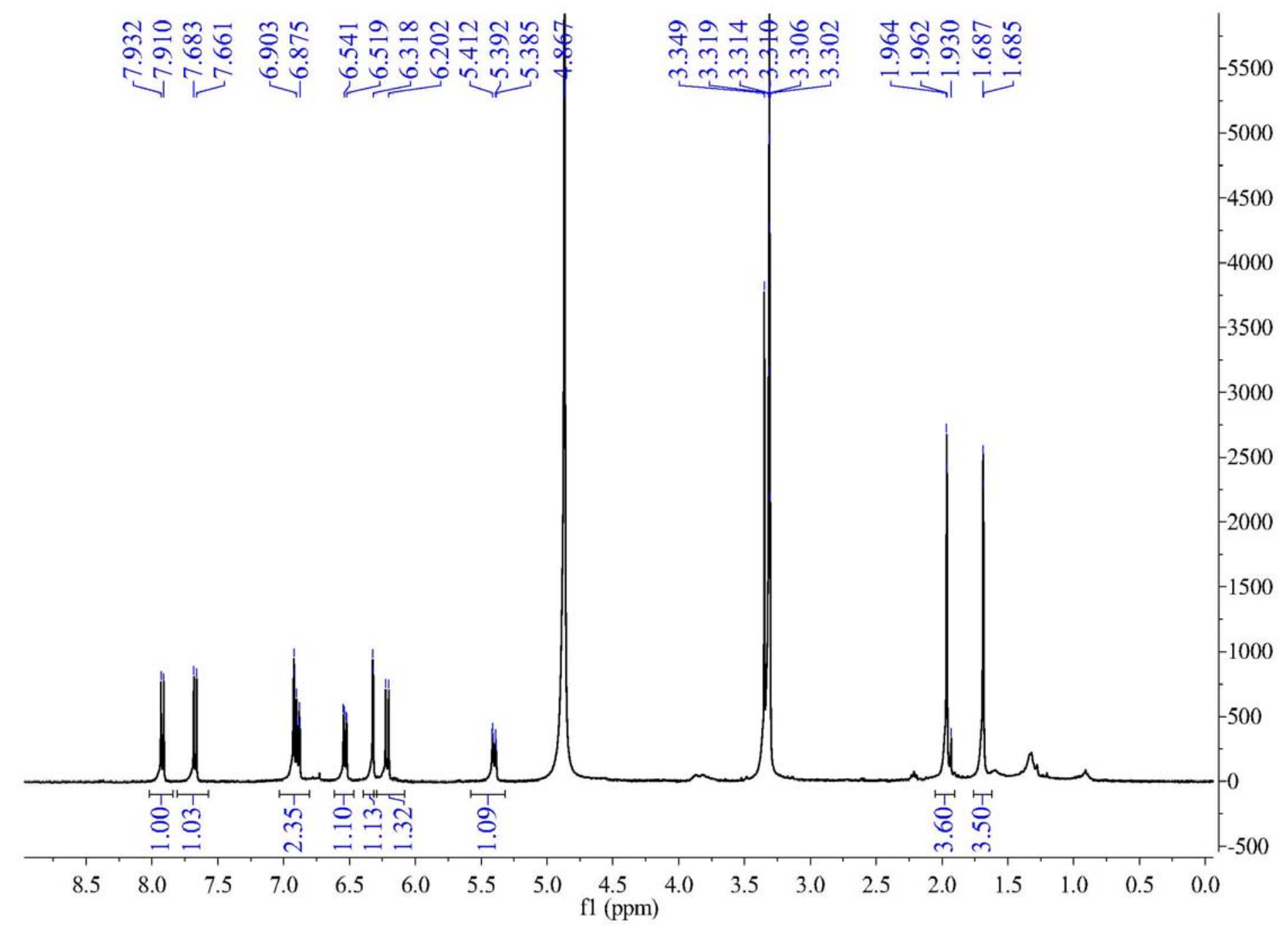

Figure S50. ${ }^{1} \mathrm{H}$ NMR spectrum of compound 6 (400 MHz, $\mathrm{CD}_{3} \mathrm{OD}$ ). 


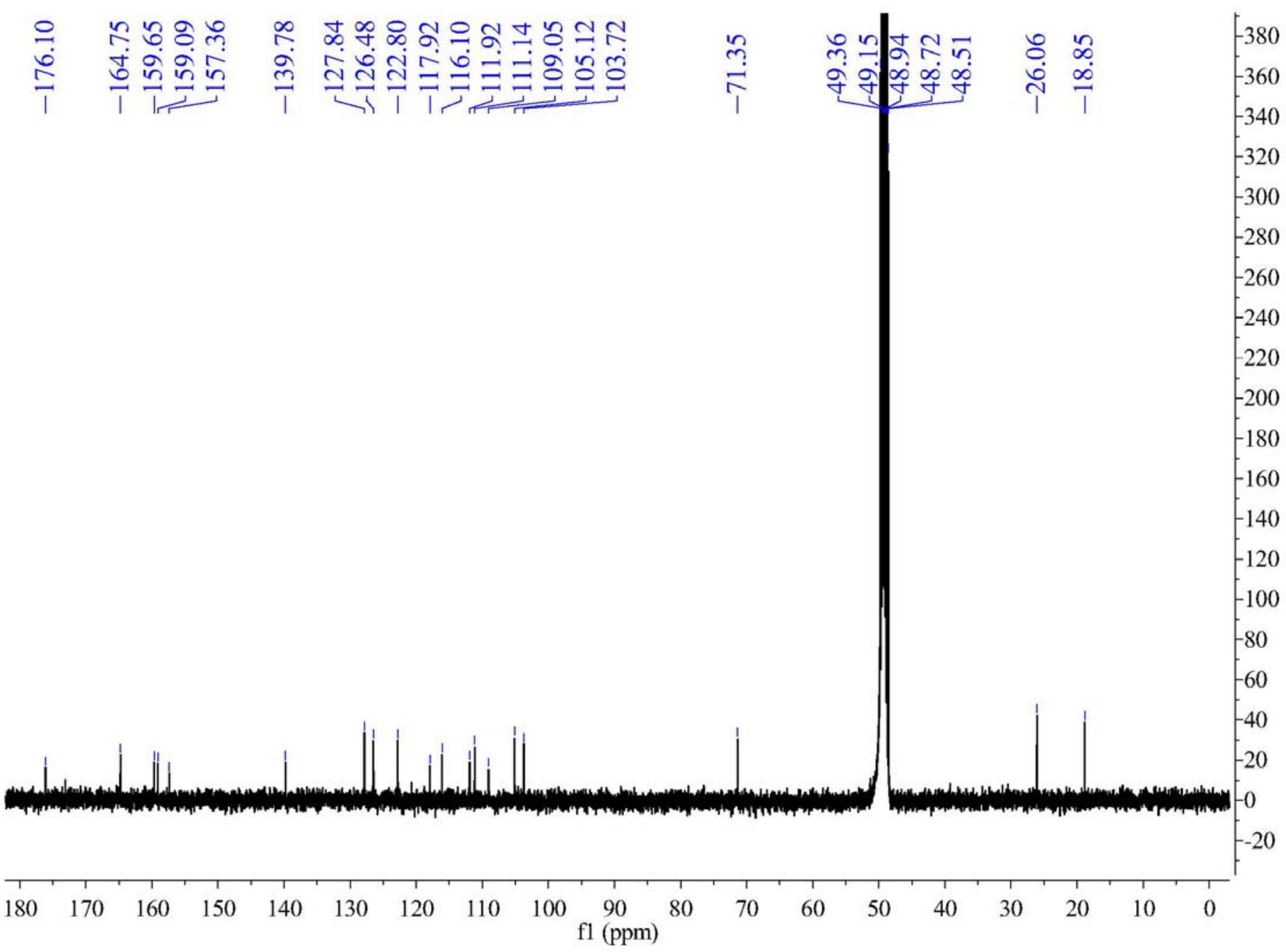

Figure S51. ${ }^{13} \mathrm{C}$ NMR spectrum of compound $6\left(100 \mathrm{MHz}, \mathrm{CD}_{3} \mathrm{OD}\right)$. 


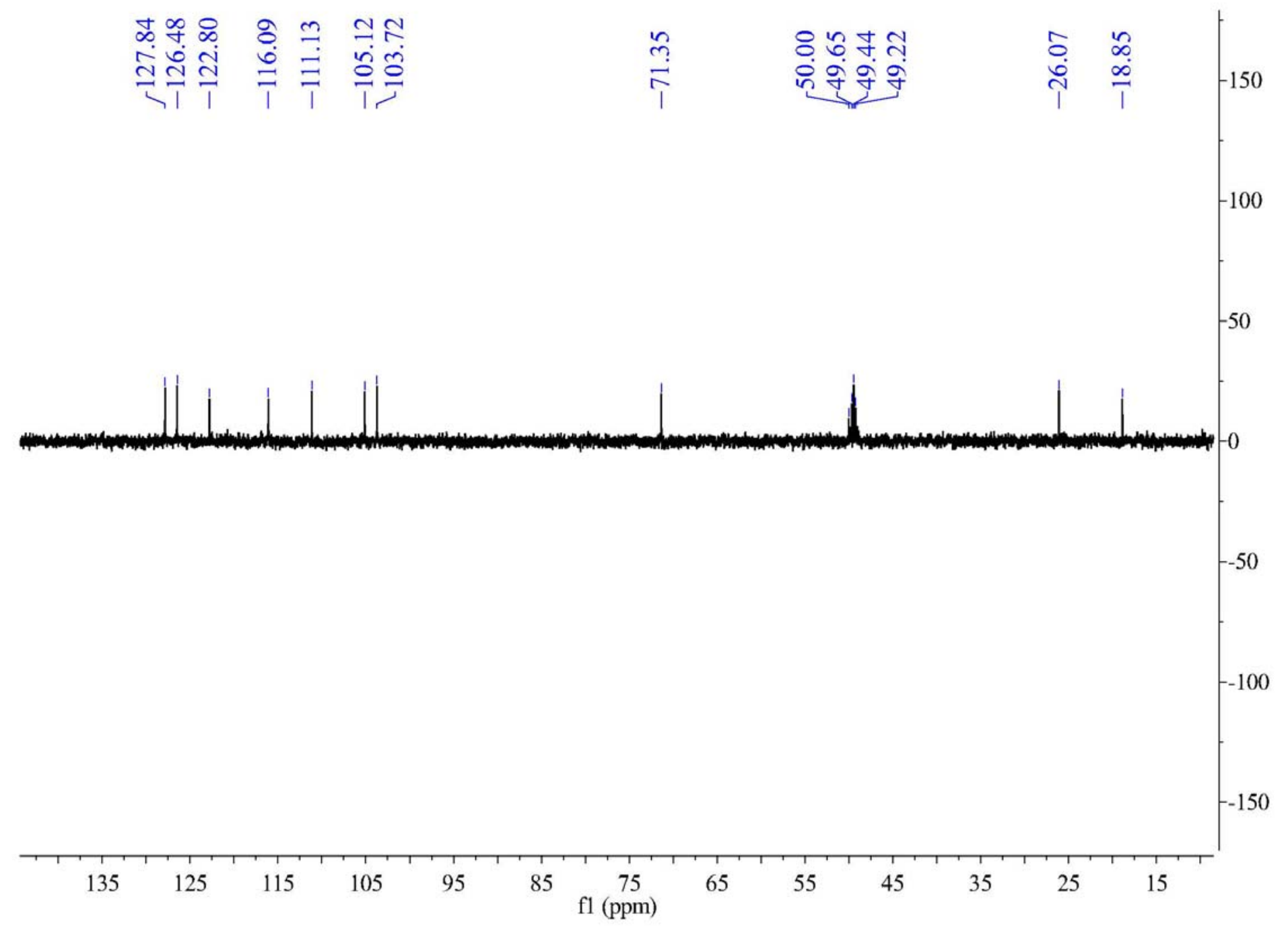

Figure S52. DEPT 135 spectrum of compound $6\left(100 \mathrm{MHz}, \mathrm{CD}_{3} \mathrm{OD}\right)$. 


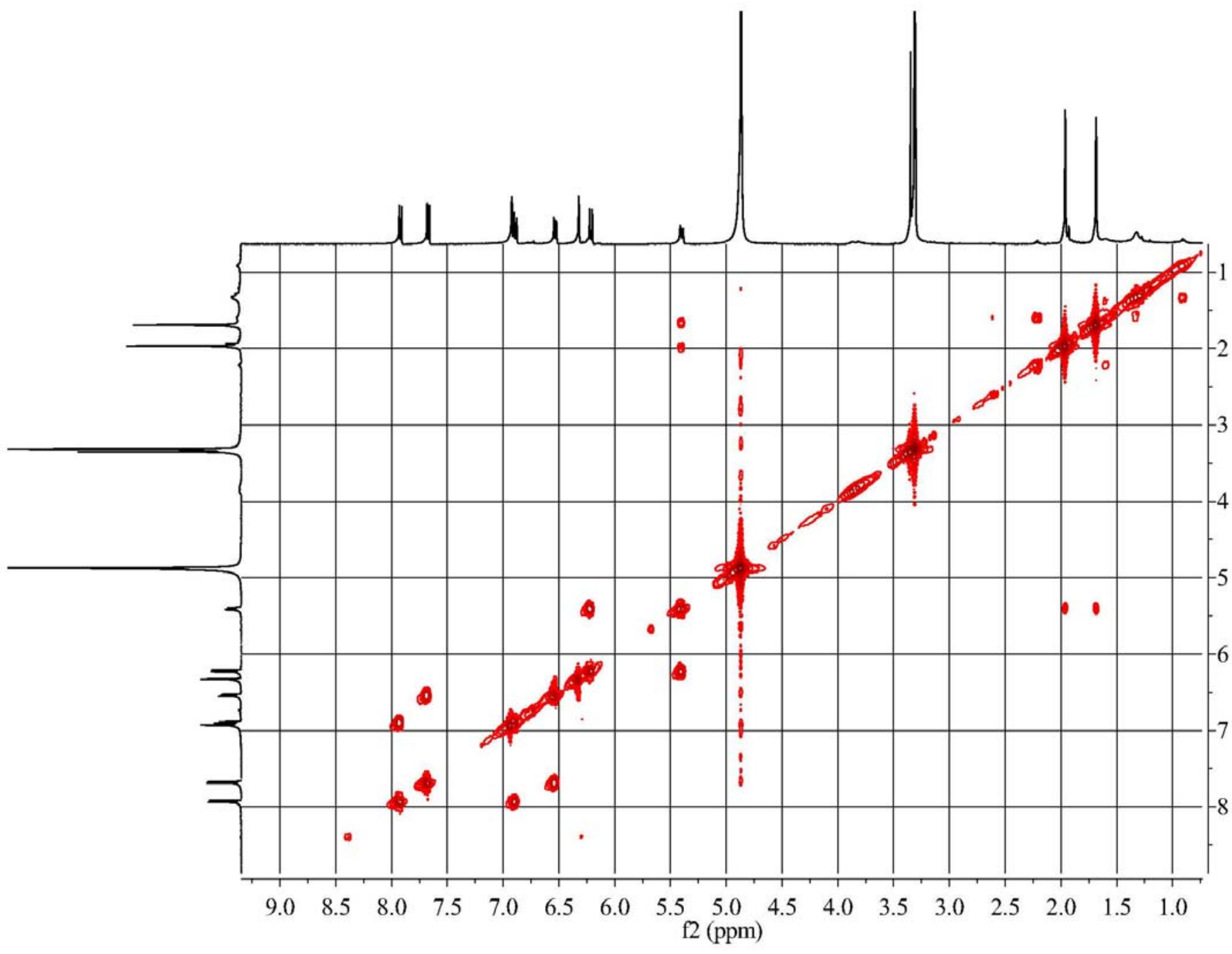

Figure S53. ${ }^{1} \mathrm{H}-{ }^{1} \mathrm{H}$ COSY spectrum of compound 6 (400 MHz, $\mathrm{CD}_{3} \mathrm{OD}$ ). 


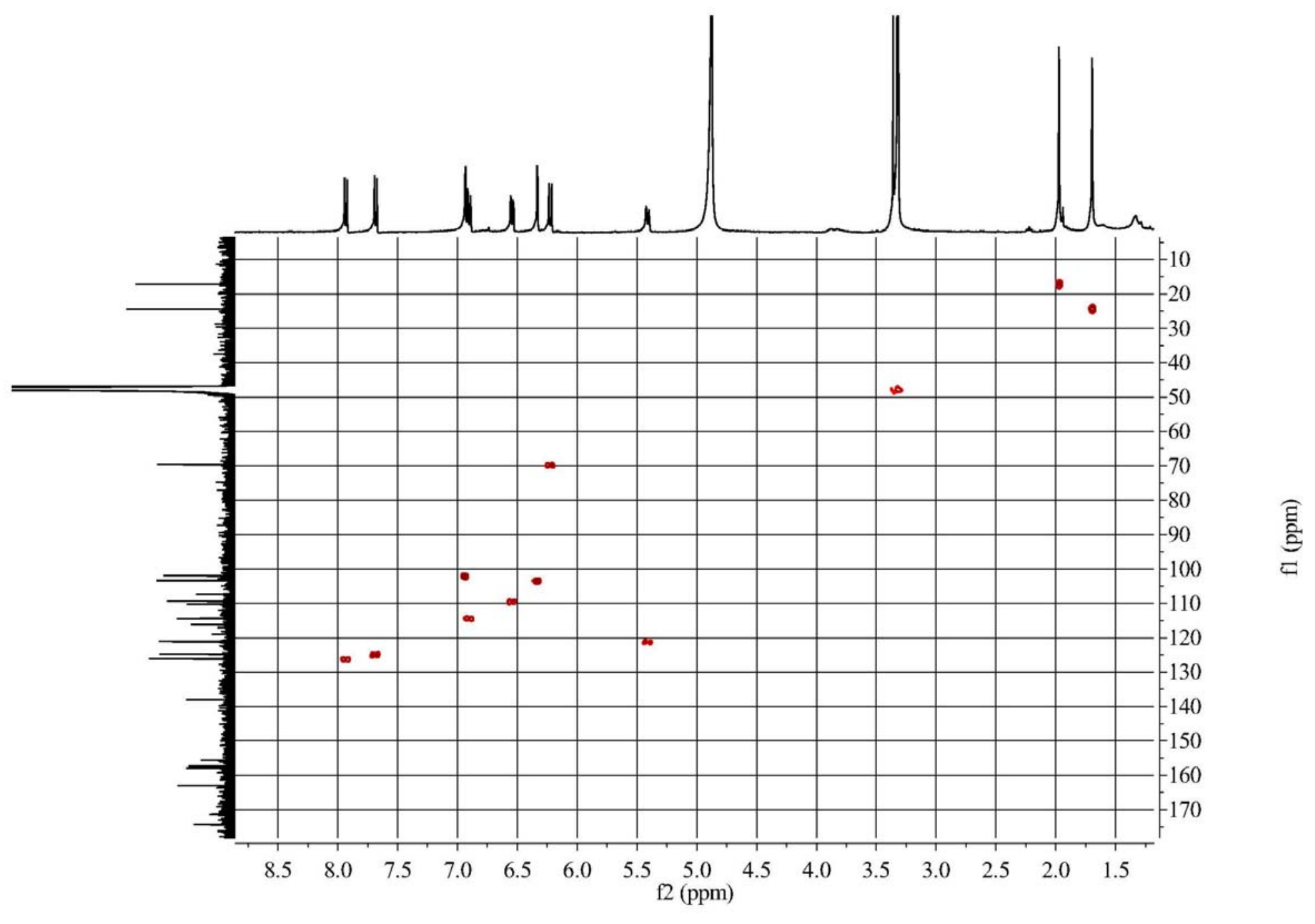

Figure S54. HSQC spectrum of compound 6 (400 and $100 \mathrm{MHz}, \mathrm{CD}_{3} \mathrm{OD}$ ). 


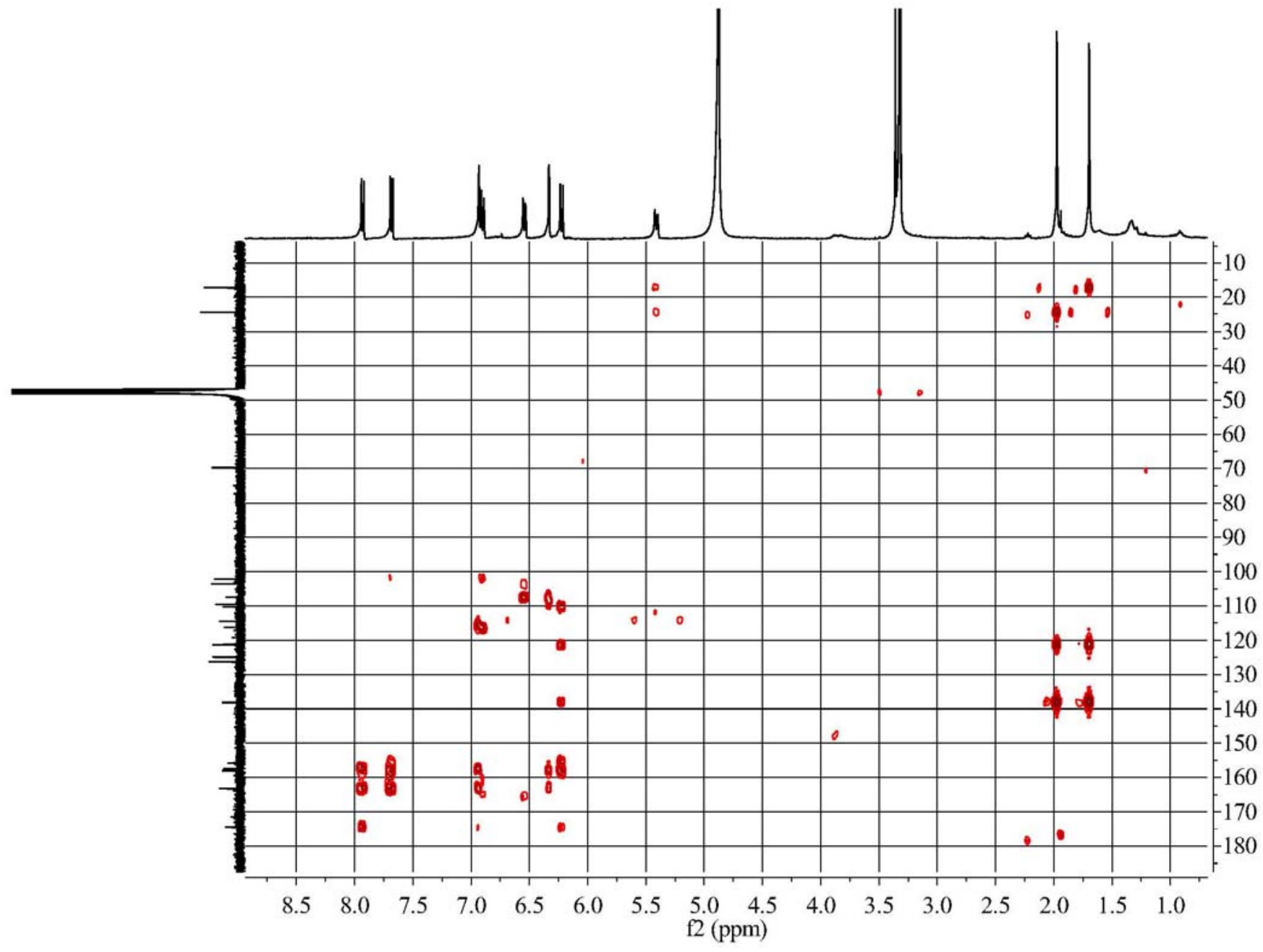

Figure S55. HMBC spectrum of compound 6 (400 and $100 \mathrm{MHz}, \mathrm{CD}_{3} \mathrm{OD}$ ). 

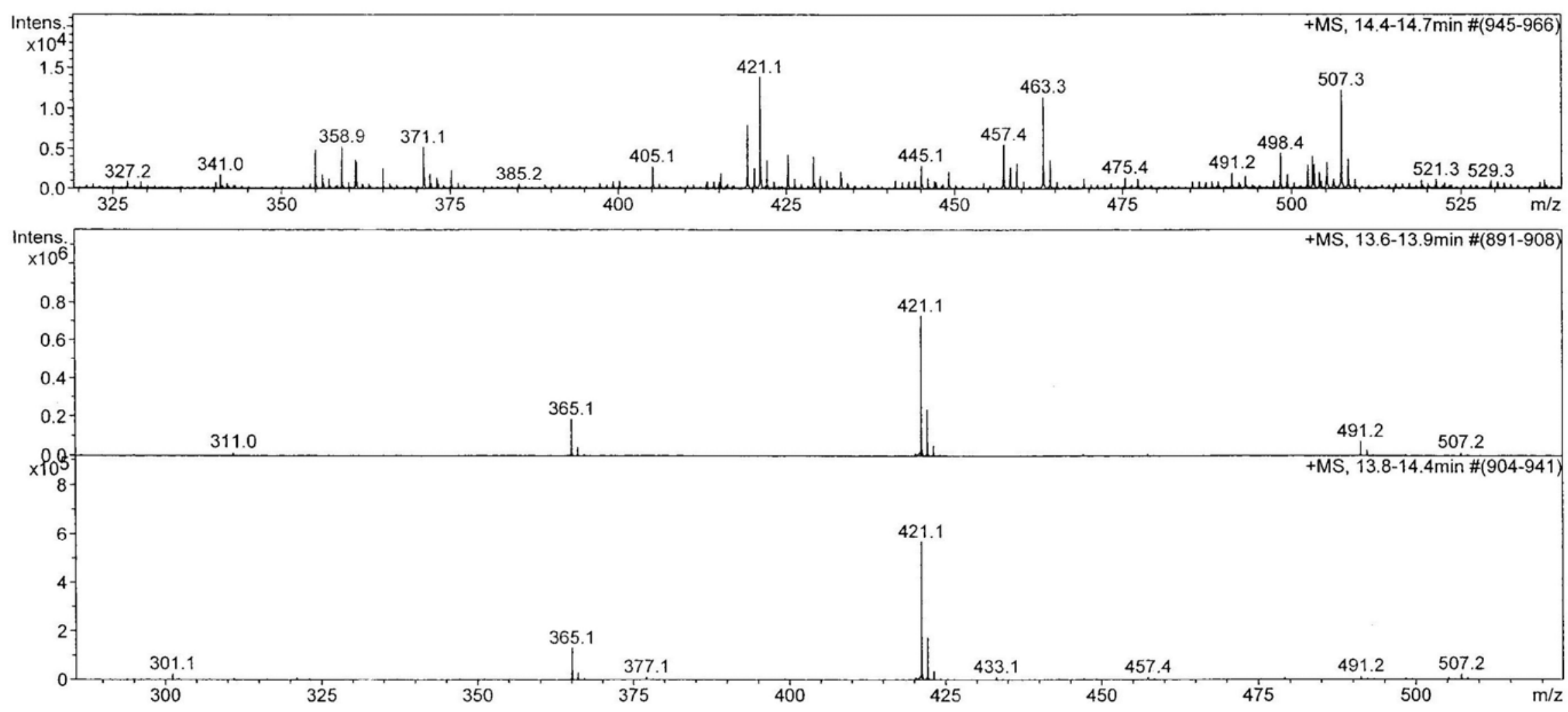

Figure S56. Positive LRESIMS spectrum of compound 7. 


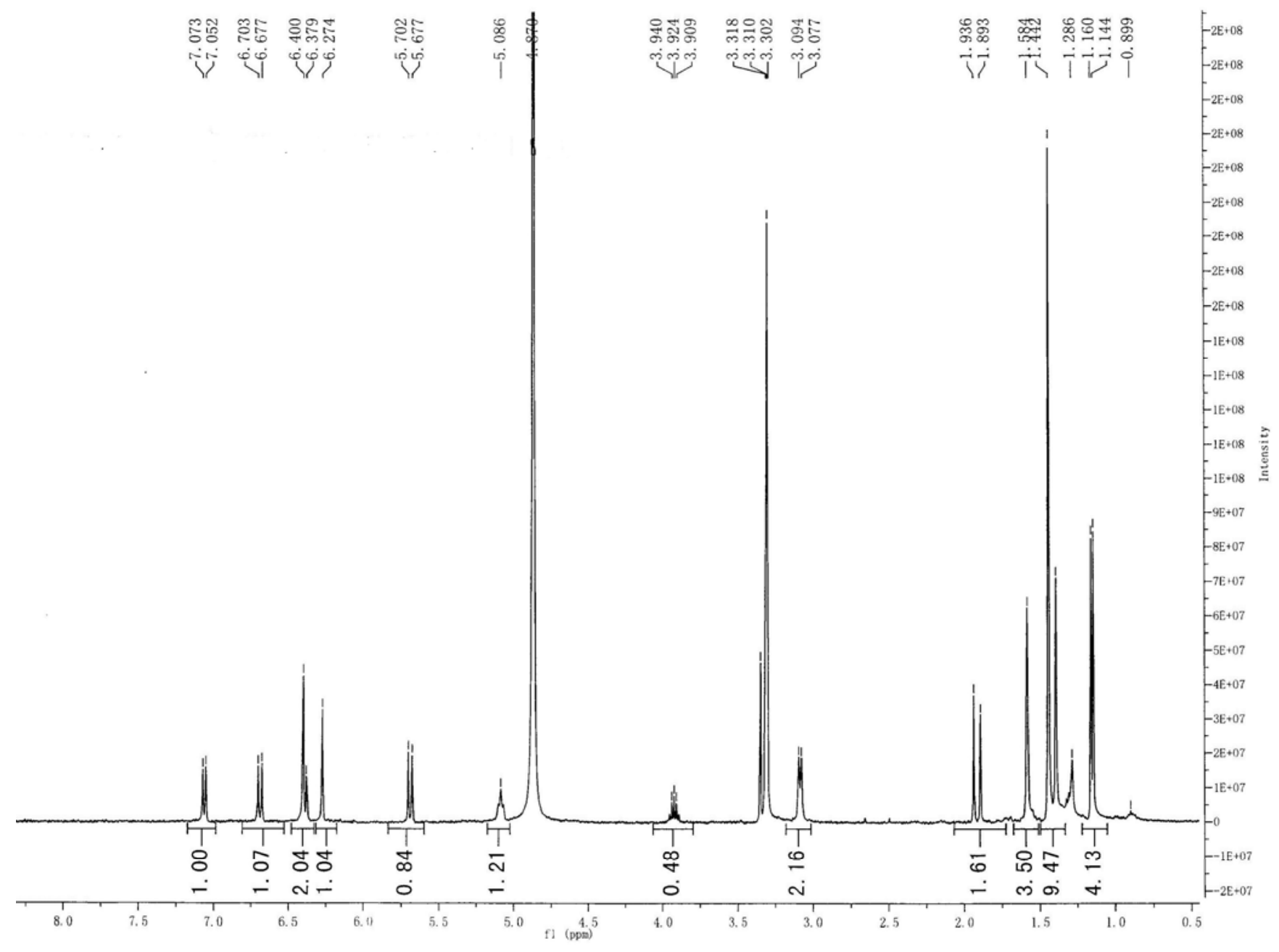

Figure S57. ${ }^{1} \mathrm{H}$ NMR spectrum of compound 7 (400 MHz, $\left.\mathrm{CD}_{3} \mathrm{OD}\right)$. 


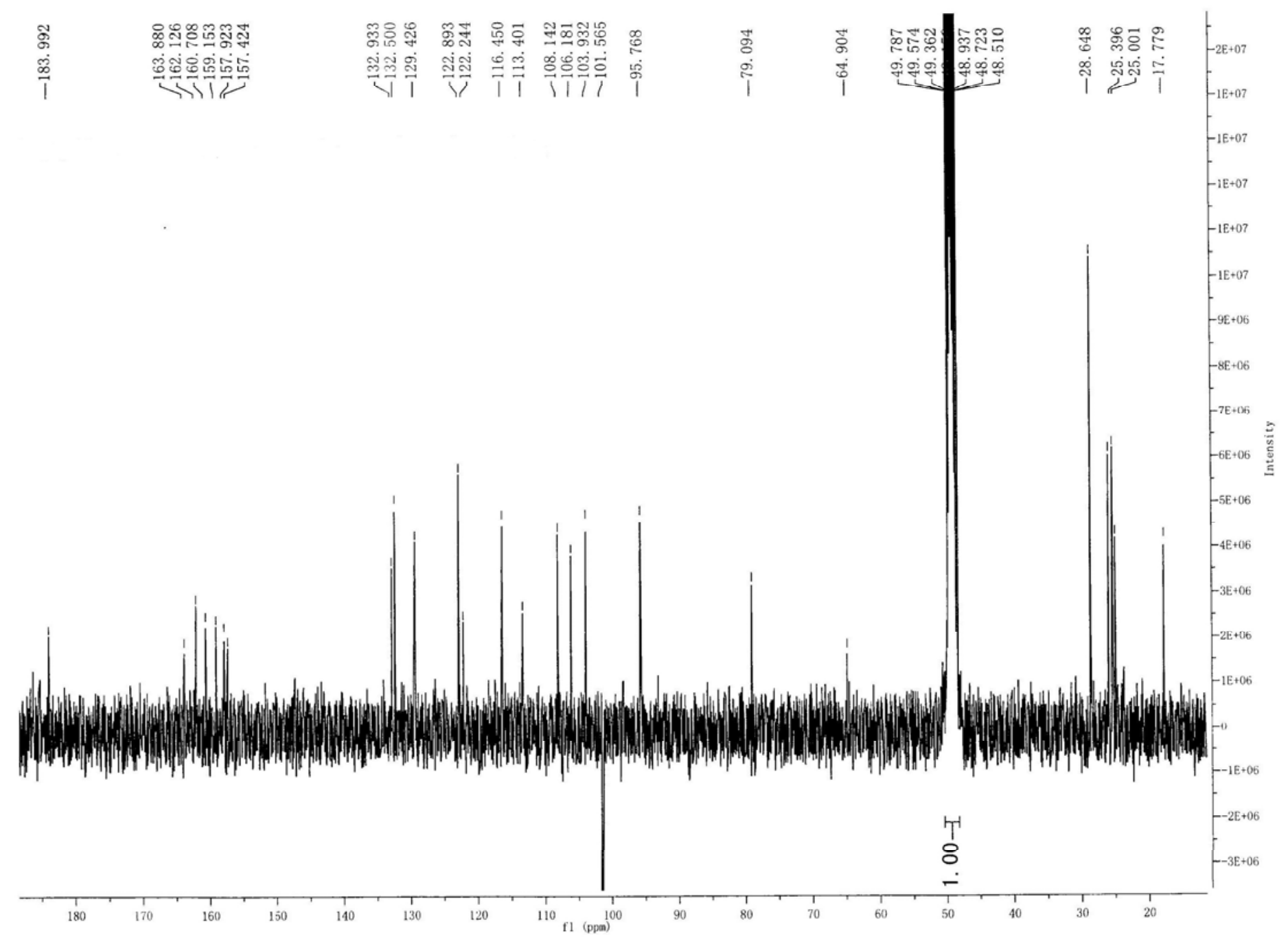

Figure S58. ${ }^{13} \mathrm{C}$ NMR spectrum of compound 7 (100MHz, $\left.\mathrm{CD}_{3} \mathrm{OD}\right)$. 


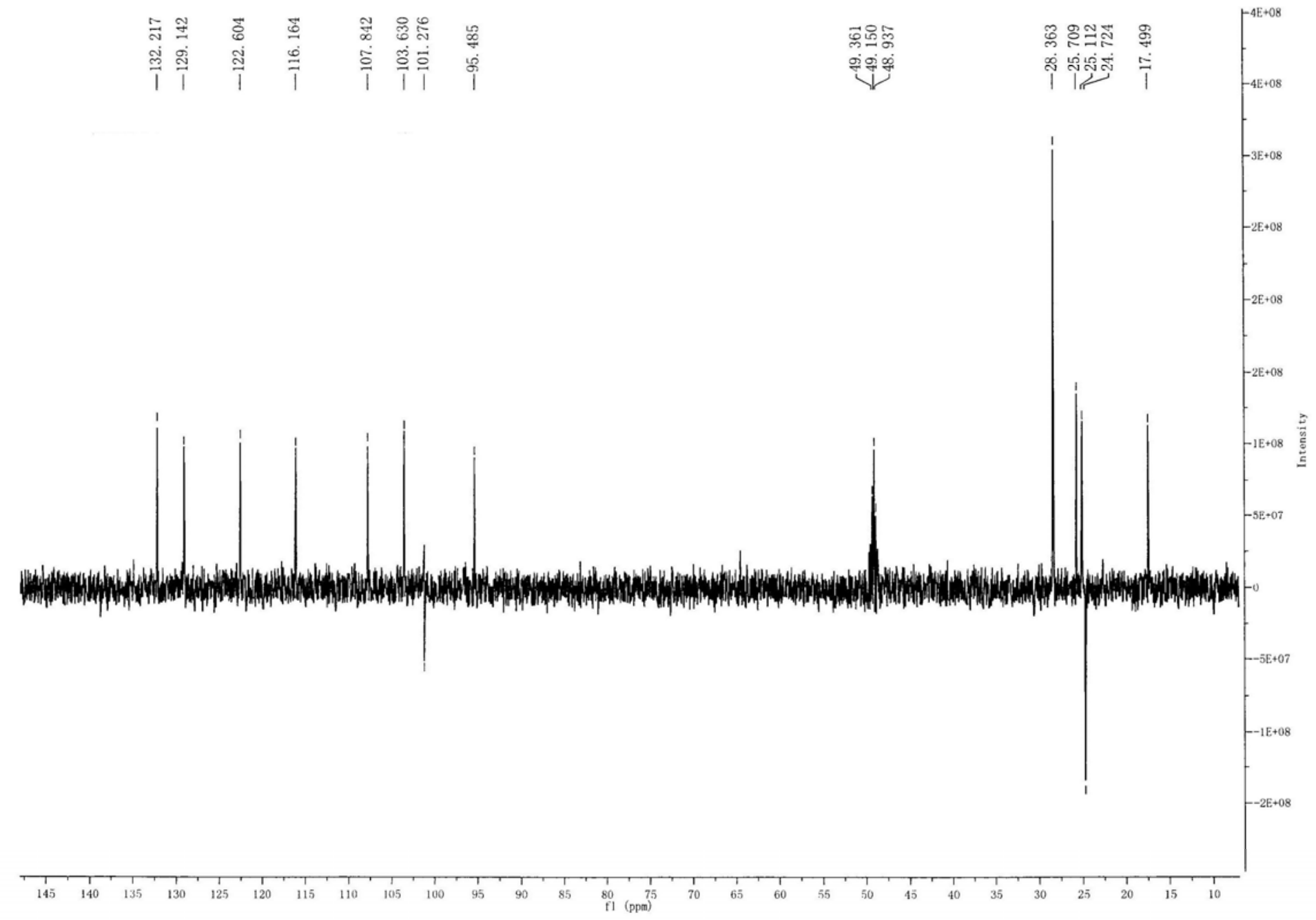

Figure S59. DEPT 135 spectrum of compound 7 (100MHz, $\left.\mathrm{CD}_{3} \mathrm{OD}\right)$. 


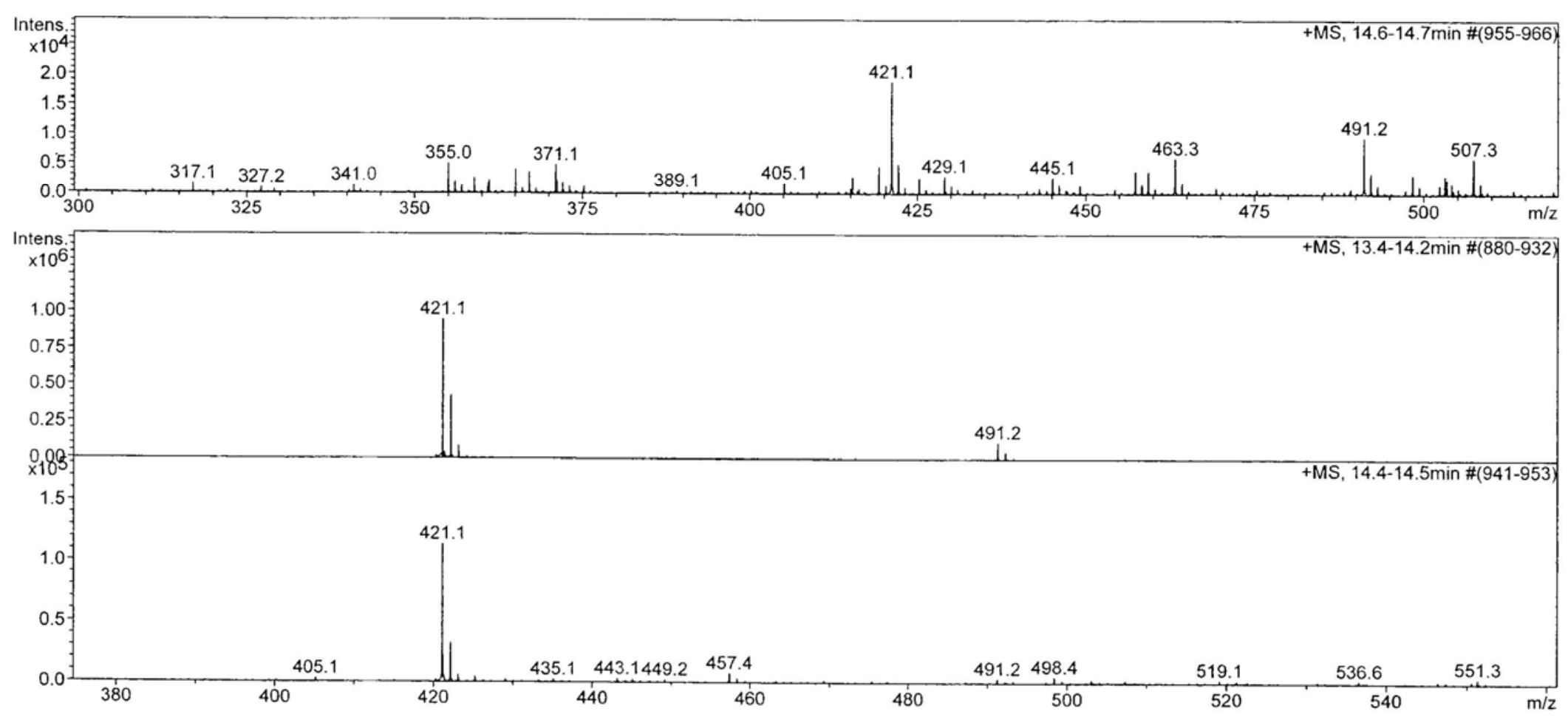

Figure S60. Positive LRESIMS spectrum of compound 8. 


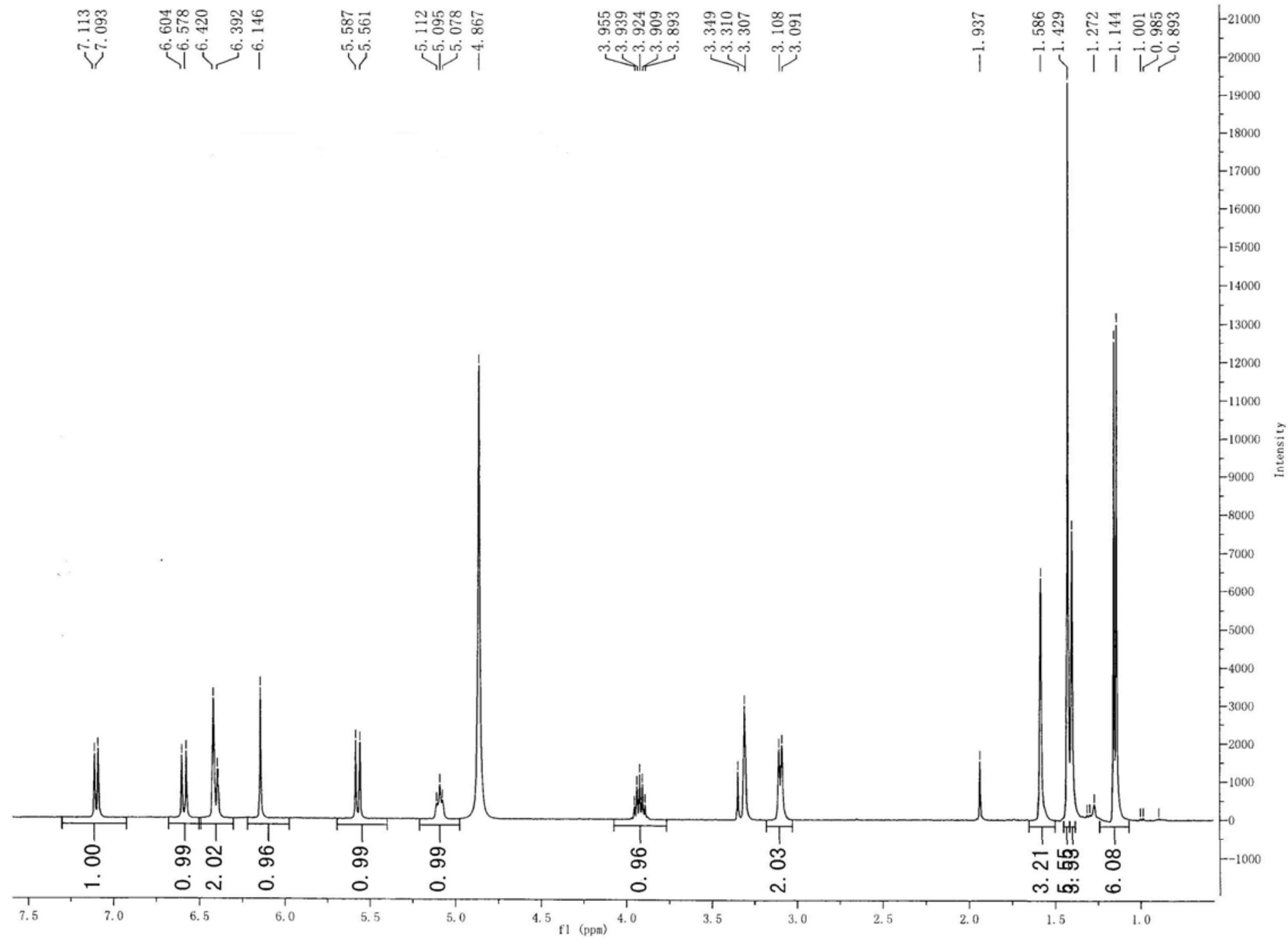

Figure S61. ${ }^{1} \mathrm{H}$ NMR spectrum of compound 8 (400 MHz, $\left.\mathrm{CD}_{3} \mathrm{OD}\right)$. 


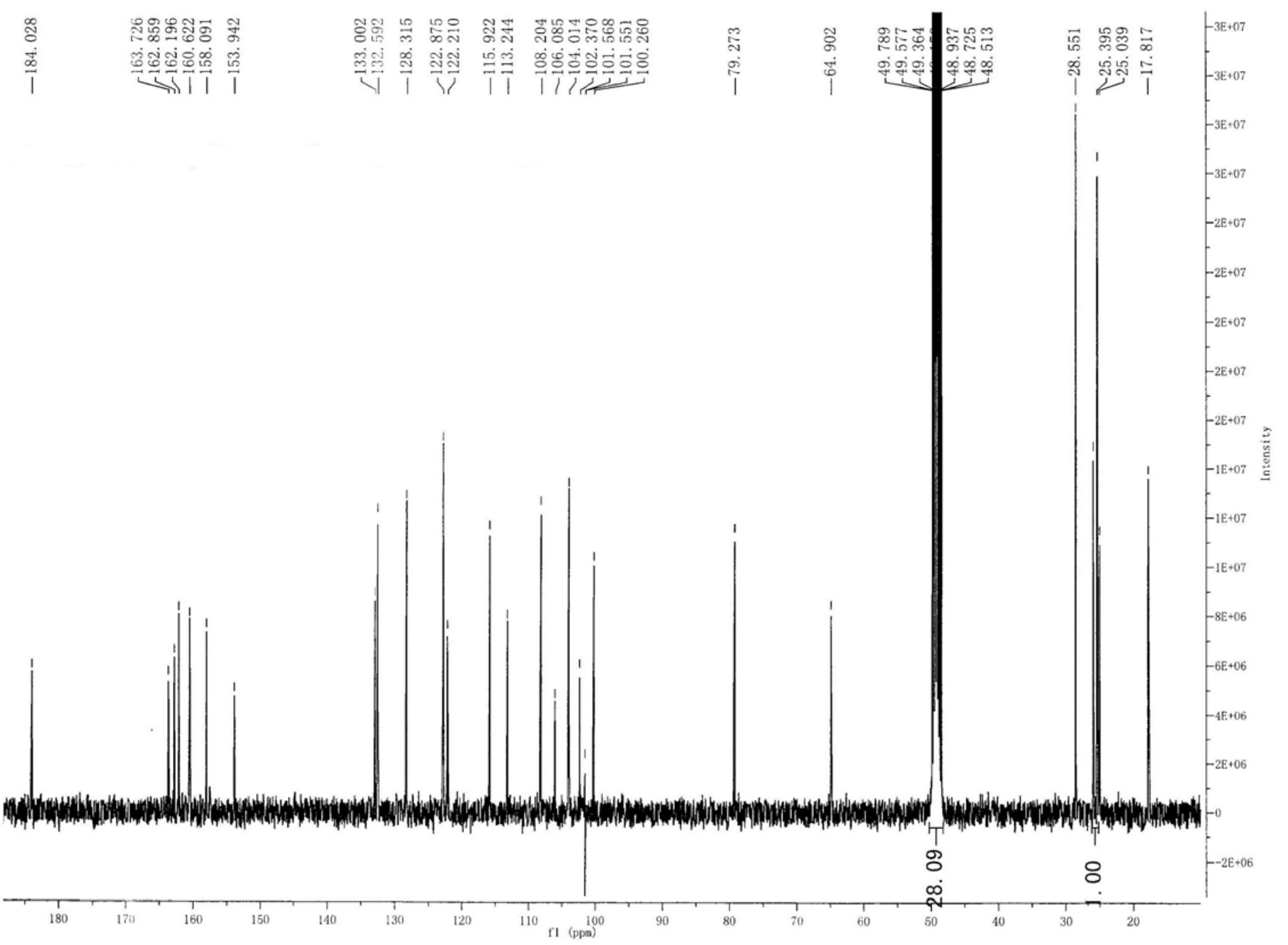

Figure S62. ${ }^{13} \mathrm{C}$ NMR spectrum of compound 8 (100MHz, $\left.\mathrm{CD}_{3} \mathrm{OD}\right)$. 


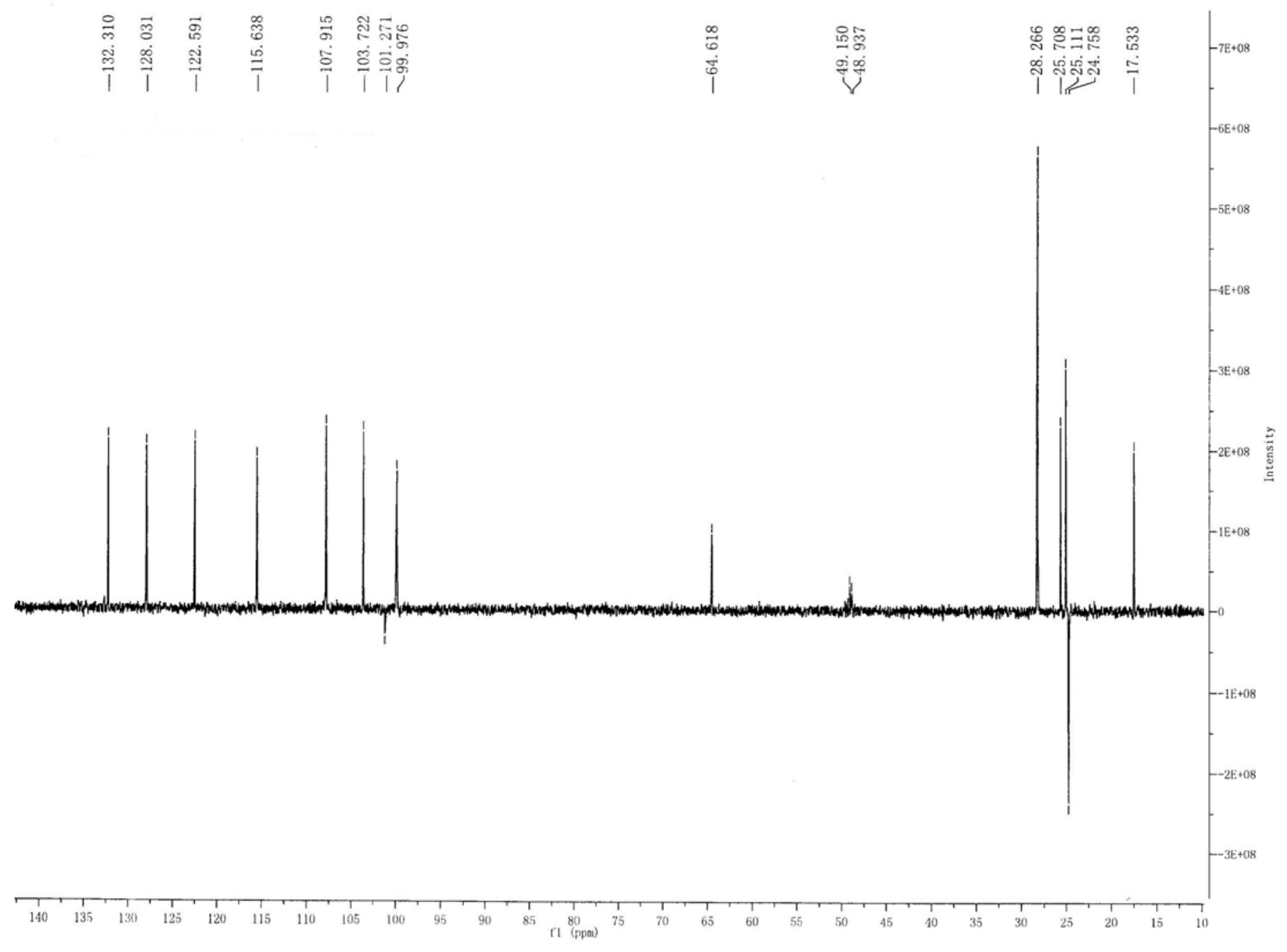

Figure S63. DEPT 135 spectrum of compound 8 (100MHz, $\left.\mathrm{CD}_{3} \mathrm{OD}\right)$. 


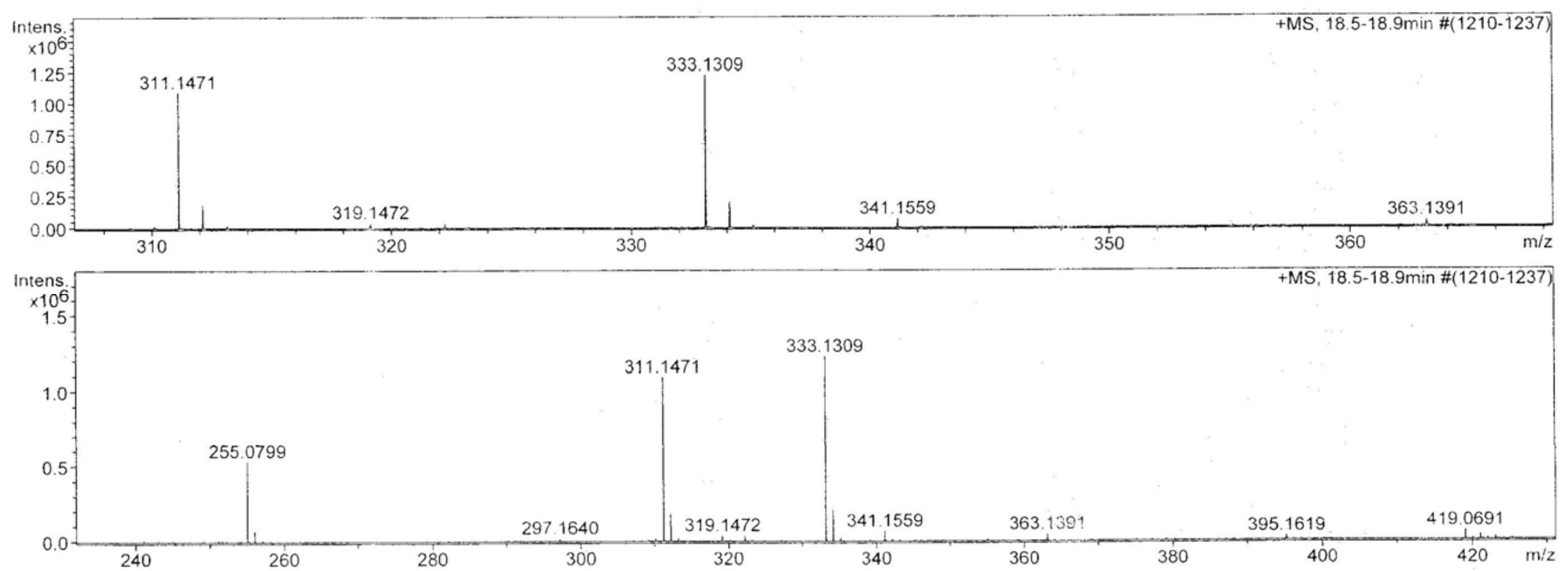

Figure S64. Positive LRESIMS spectrum of compound 9. 


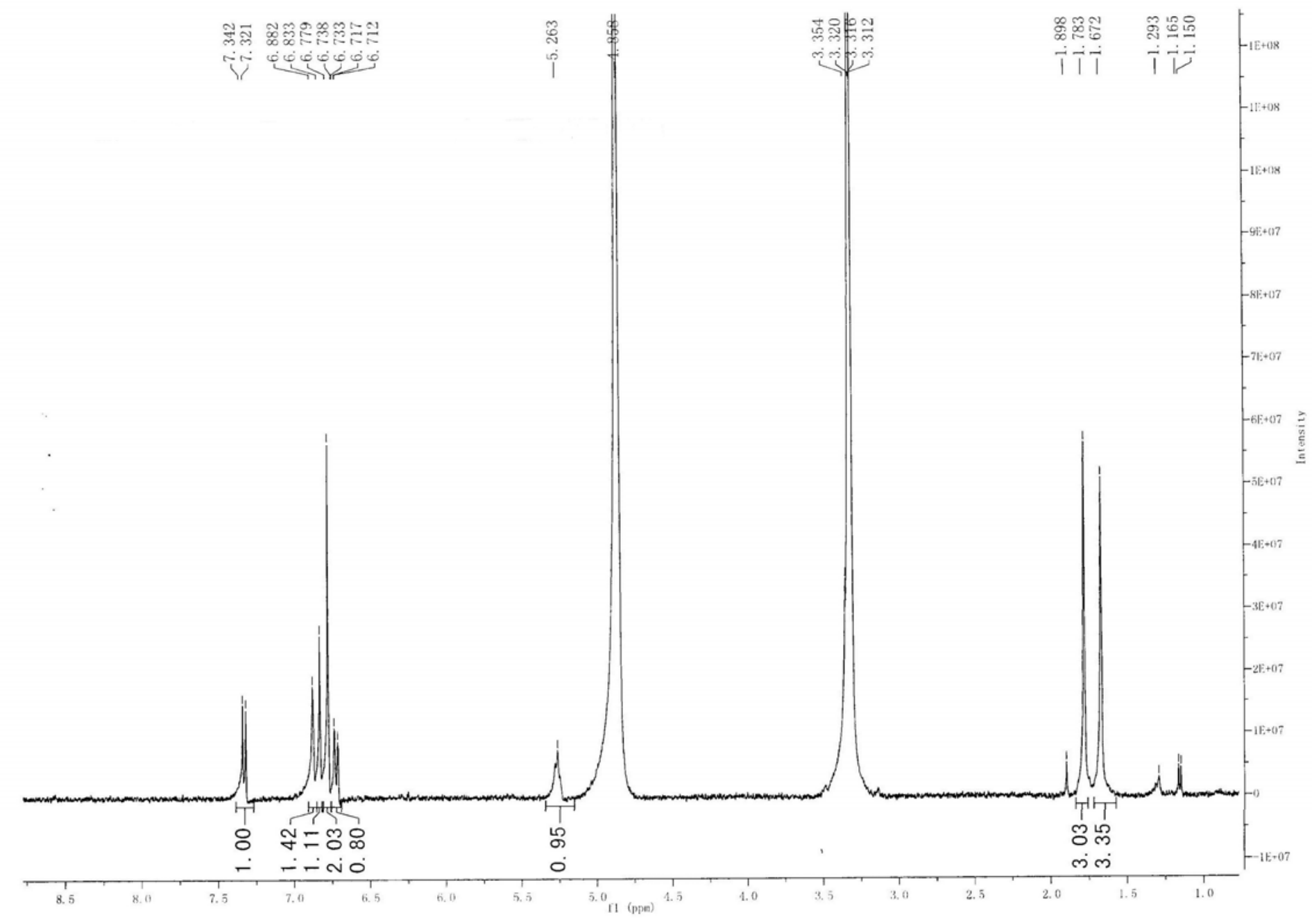

Figure S65. ${ }^{1} \mathrm{H}$ NMR spectrum of compound 9 (400 MHz, $\left.\mathrm{CD}_{3} \mathrm{OD}\right)$. 


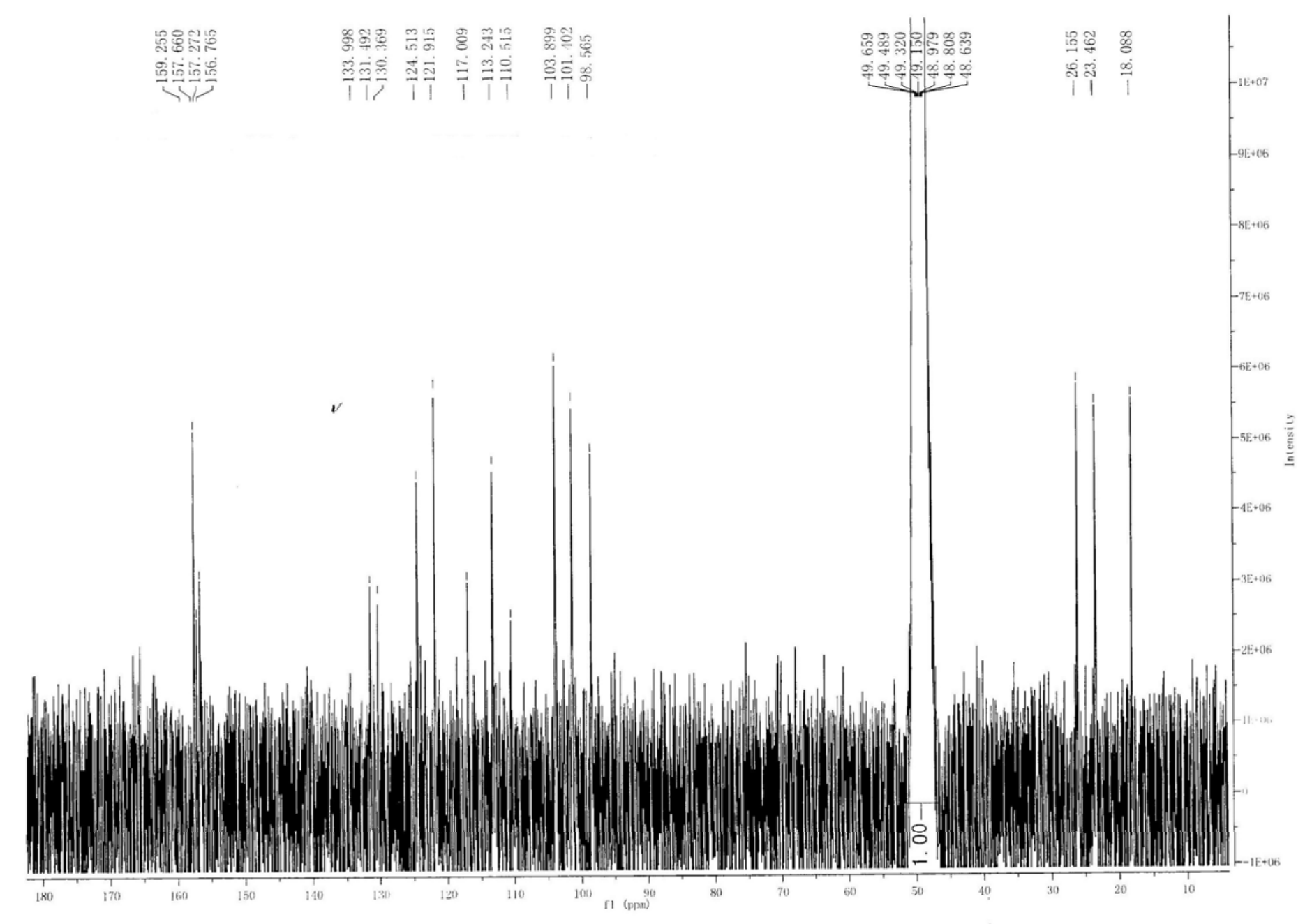

Figure S66. ${ }^{13} \mathrm{C}$ NMR spectrum of compound 9 (100MHz, $\left.\mathrm{CD}_{3} \mathrm{OD}\right)$. 


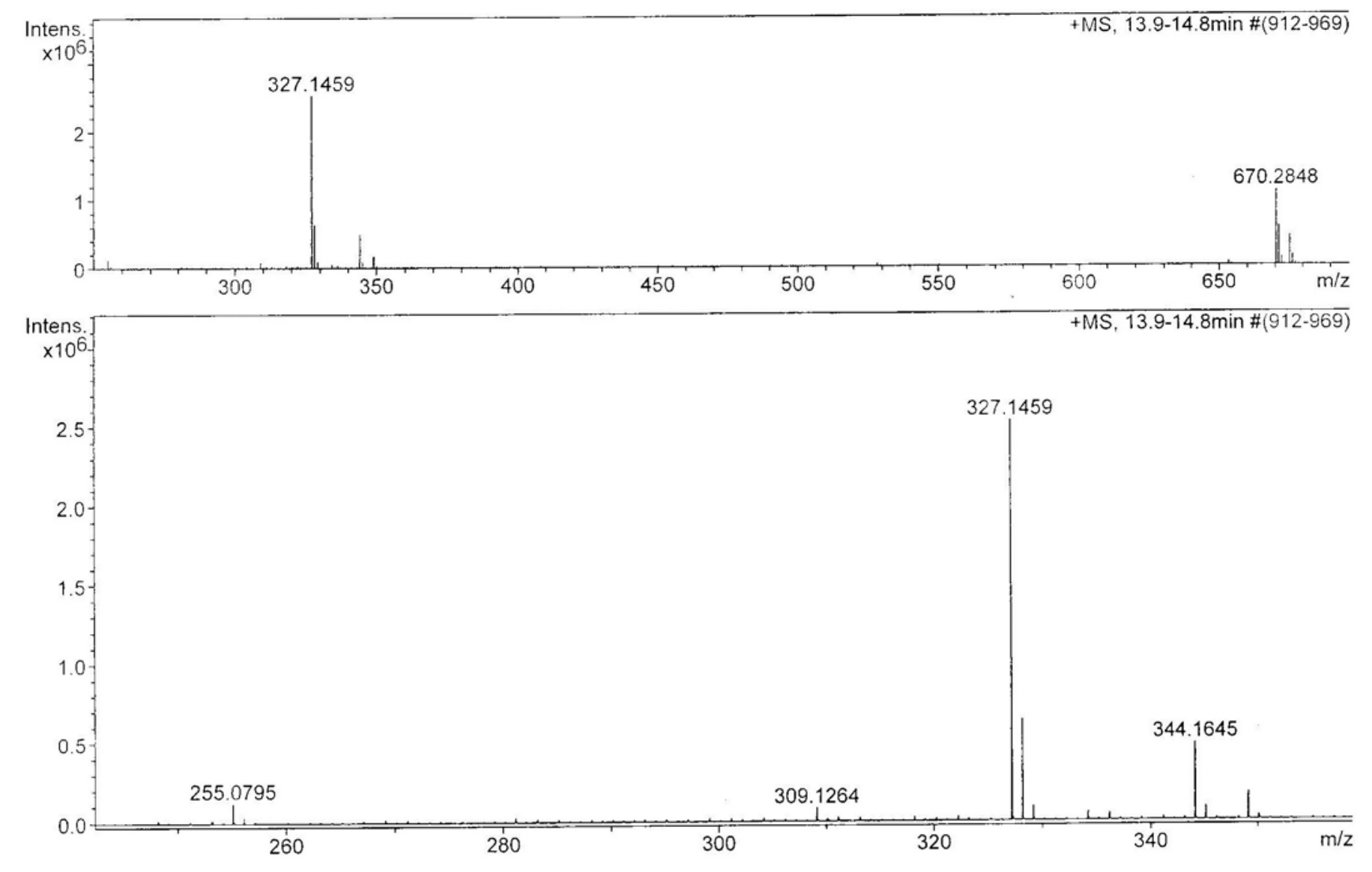

Figure S67. Positive LRESIMS spectrum of compound 10. 


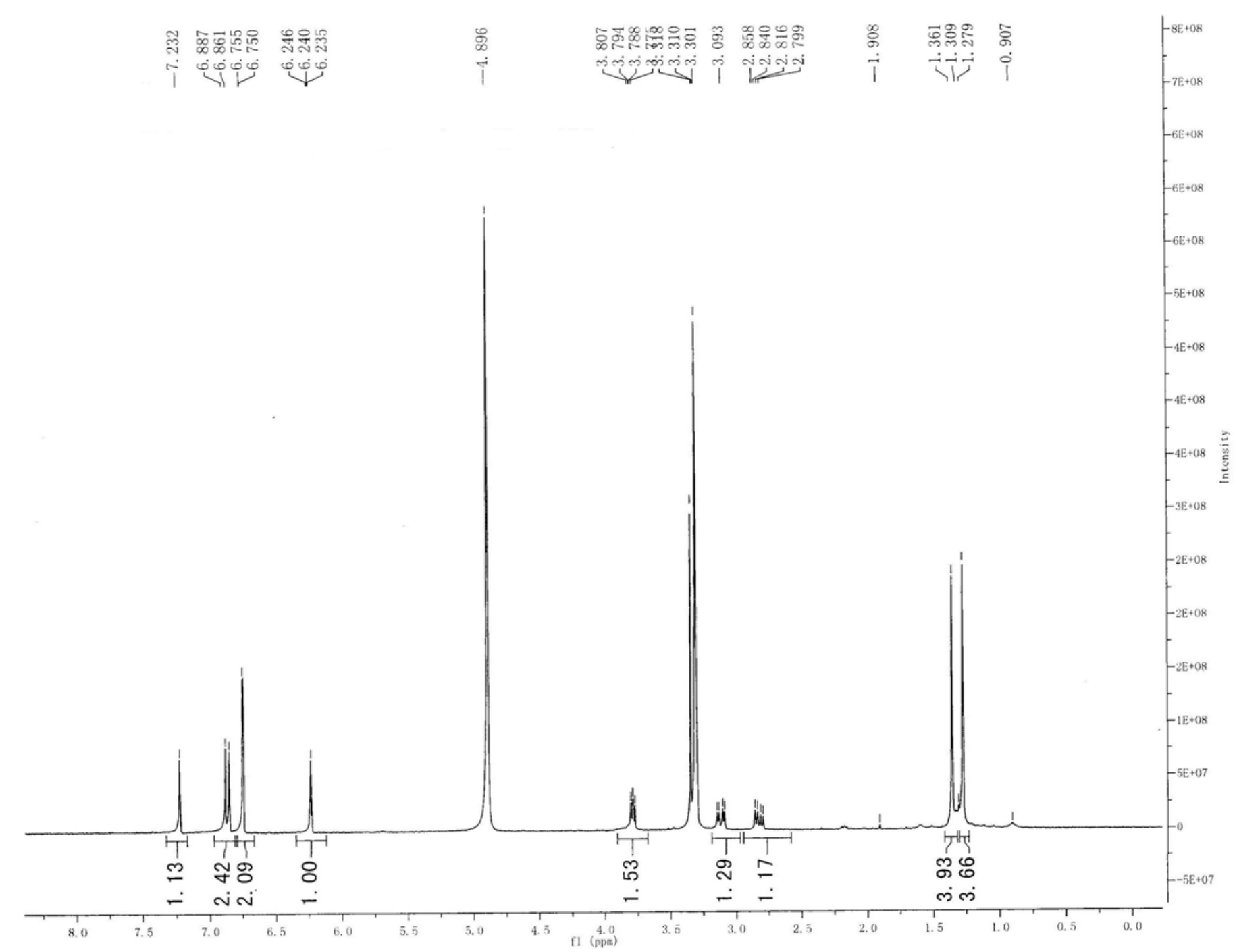

Figure S68. ${ }^{1} \mathrm{H}$ NMR spectrum of compound 10 (400 MHz, $\left.\mathrm{CD}_{3} \mathrm{OD}\right)$. 